UNIVERSIDAD DE SALAMANCA

FACULTAD DE ECONOMÍA Y EMPRESA

Departamento de Administración y Economía de la Empresa

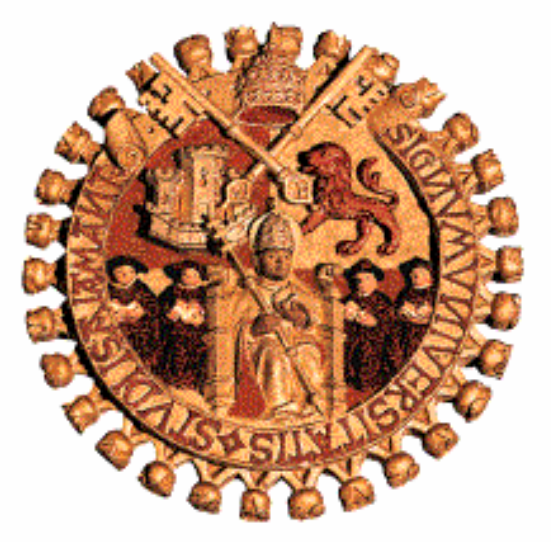

\title{
A TRADE CREDIT EXPLANATION BASED ON THE AGENCY THEORY, LEGAL FACTORS AND CREDIT CONTAGION
}

\author{
Rafael Rabelo Bastos
}

Doctoral thesis supervised by Professor:

Dr. Julio Pindado García

Salamanca, 2010 


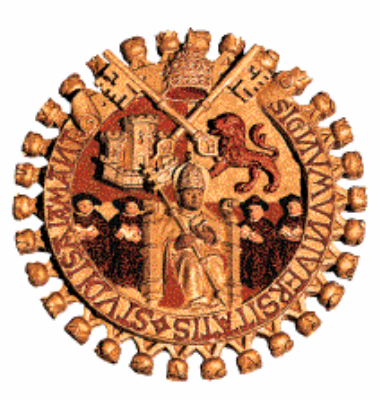

UNIVERSIDAD DE SALAMANCA

FACULTAD DE ECONOMÍA DE EMPRESA

DEPARTAMENTO DE ADMINISTRACIÓN Y ECONOMIA

DE LA EMPRESA

\section{A TRADE CREDIT EXPLANATION BASED ON THE AGENCY THEORY, LEGAL FACTORS AND CREDIT CONTAGION}

Trabajo presentado para optar al título de Doctor en Administración y

Dirección de Empresas, por D. Rafael Rabelo Bastos bajo la dirección del profesor Dr. D. Julio Pindado Garcia

Dr. D. Julio Pindado Garcia

Director

Fdo. D.: Rafael Rabelo Bastos

Doctorando

Salamanca, marzo de 2010 
Facultad de Economía y Empresas

Campus Miguel de Unamuno, S/N

37007 Salamanca, Spain

Tel.: +34923294640 Ext. 3506

Fax.: +34923294 715

Universidad de Salamanca

Departamento de Administración y Economía de la Empresa

\section{Autorización para la presentación de la tesis doctoral}

(Art. 8.1. del Real Decreto 778/1998, de 30 de abril)

JULIO PINDADO GARCIA, como director de la tesis doctoral "A trade credit explanation based on the agency theory, legal factors and credit contagion", realizada por D. Rafael Rabelo Bastos, autorizo su presentación para la obtención del grado de doctor en la Universidad de Salamanca, pues considero cumple todos los requisitos necesarios para su defensa y para que así conste, a los efectos oportunos, firmo la presente en Salamanca a 30 de marzo de 2010.

Dr. Julio Pindado García

Catedrático de Economía Financiera

Universidad de Salamanca 
To my parents, Claudio and Vera

To my brother, Claudio Rabelo To my wife, Carol

For unconditional support 


\section{Acknowledgments}

The following is my heartfelt gratitude to those who gave me the force, attitude and support to persevere and not to give up in the arduous but rewarding way of knowledge.

I would like to thank the Departamento de Administración y Economía de la Empresa de la Universidad de Salamanca, where I found a very positive and stimulating work environment. In particular I thank professor Pablo Muñoz Gallego for the backing he gave me in the whole period that I stayed at the university.

I specially thank my thesis director, Professor Julio Pindado Garcia. He has patiently listened, read, commented and encouraged me during these years. His critical analyses, attention to details and aid have been a valuable fuel and incentive to finish this thesis.

Warm thanks to my fellow $\mathrm{PhD}$ students and other friends who provided me with good times, discussions, help and shared important moments and feelings.

I also thank the Faculdade Ateneu and the Instituto Federal de Educação, Ciência e Tecnologia do Ceará, Brazil, for endorsing and allowing me to be absent from my activities there, giving me the possibility to dedicate myself to the research activity.

Yet my greatest thanks belong to my family. To Carol, my wife, for understanding me and for giving me all her love. To my parents, Claudio Bastos and Vera Bastos, for all the emotional support and for teaching me the importance of persistence in the achievement of success in all aspects of life. Finally, to my brother and friend, Claudio Rabelo, for the constant motivation. 


\section{Table of Contents}

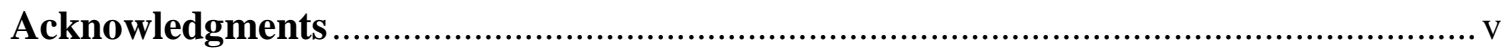

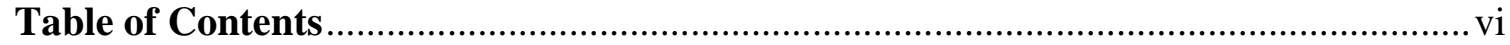

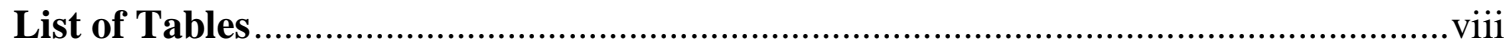

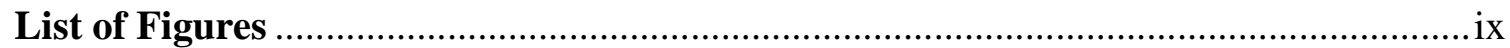

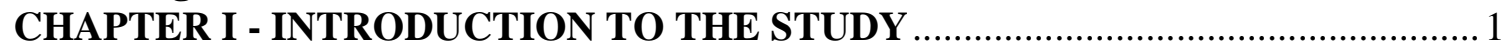

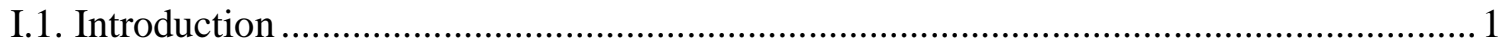

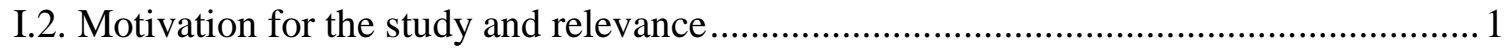

I.3. The different environments that have an impact on trade credit supply and demand...... 2

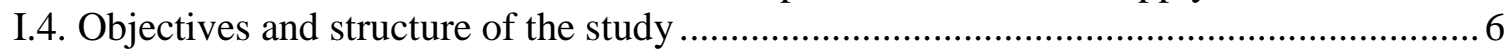

CHAPTER II - AN AGENCY MODEL TO EXPLAIN TRADE CREDIT POLICY

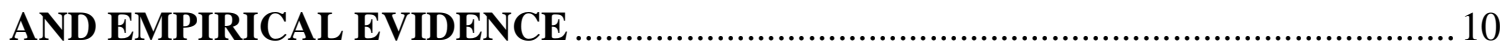

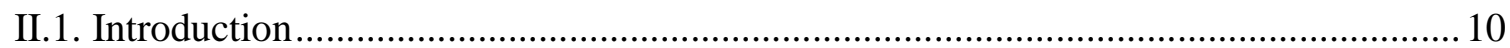

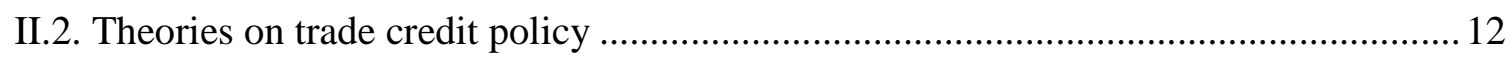

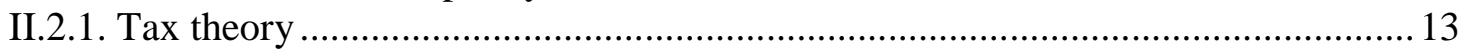

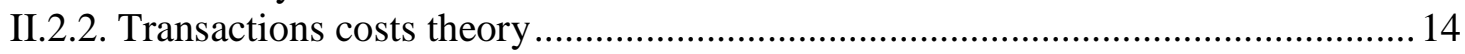

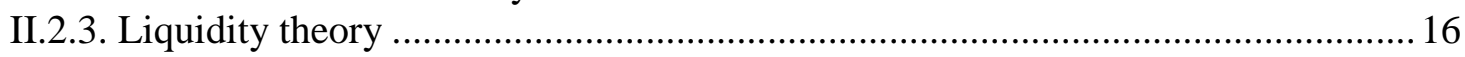

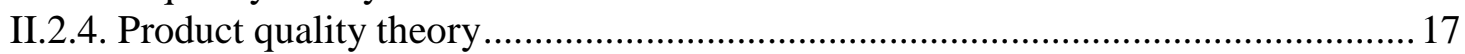

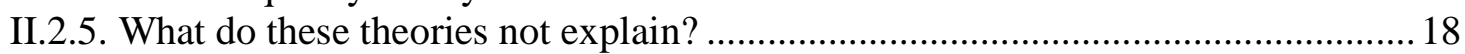

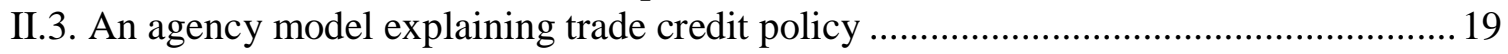

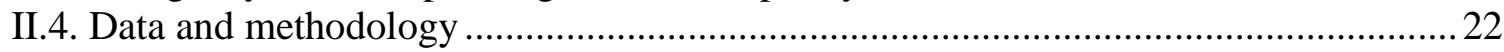

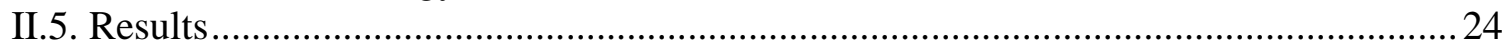

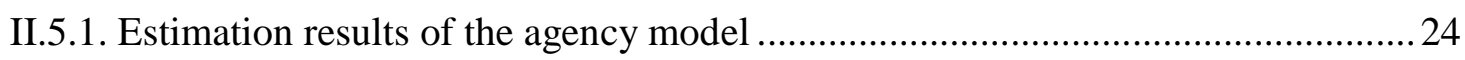

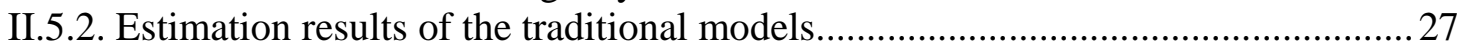

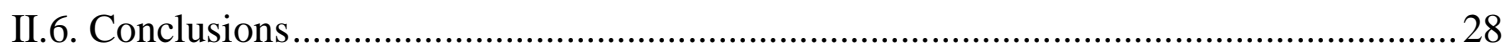

CHAPTER III - TRADE CREDIT, CREDITOR PROTECTION AND ACCOUNTING STANDARDS: EVIDENCE FROM AN INTERNATIONAL

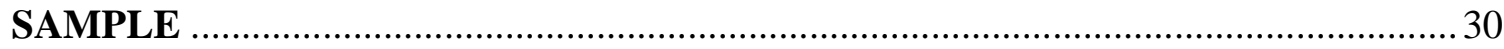

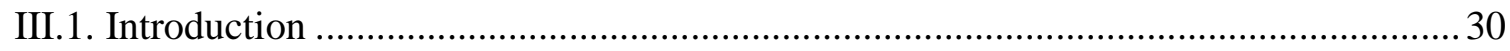

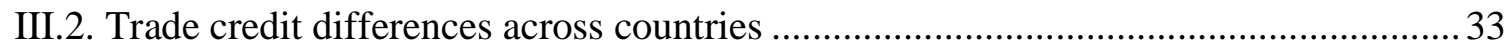

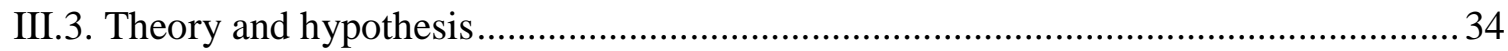

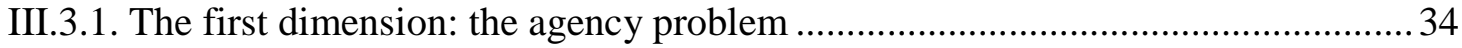

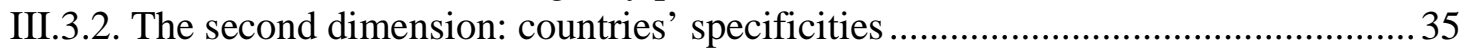

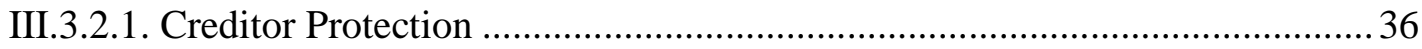

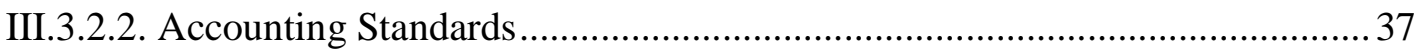

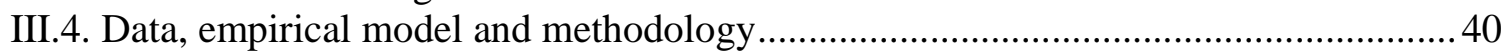

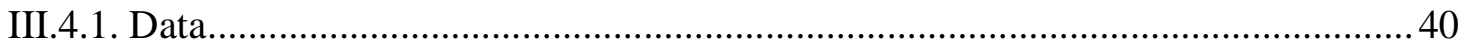

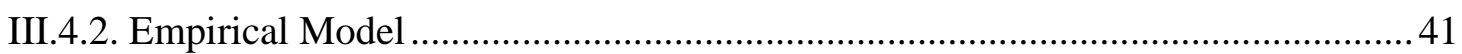

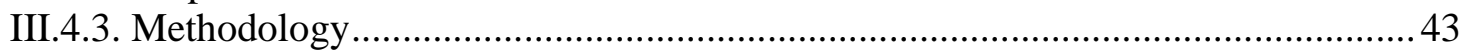

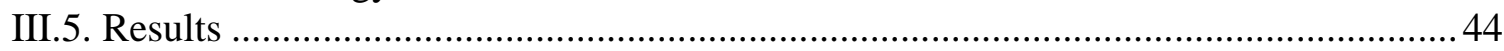

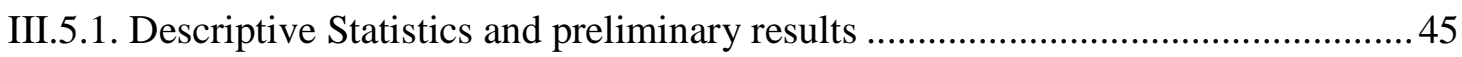

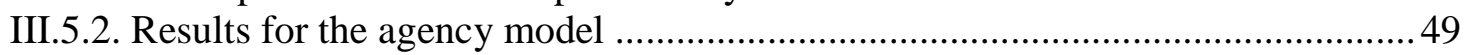

III.5.3. The moderating role of creditors' rights....................................................... 51

III.5.4. The moderating role of the quality of the accounting system .............................52

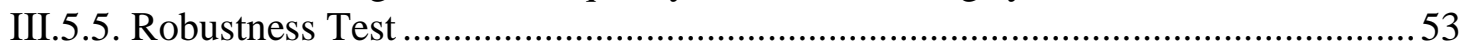


III.6. Conclusions

CHAPTER IV - TRADE CREDIT DURING AN ECONOMIC CRISIS: A PANEL

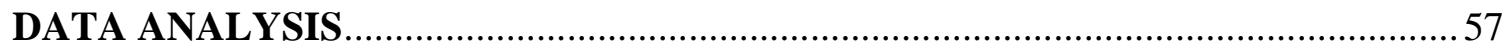

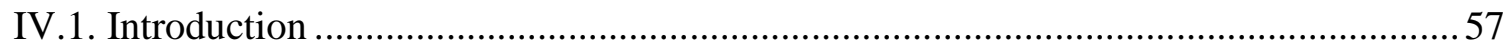

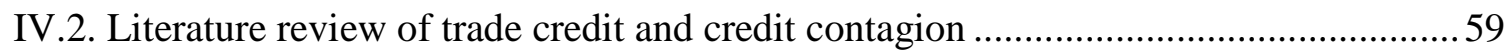

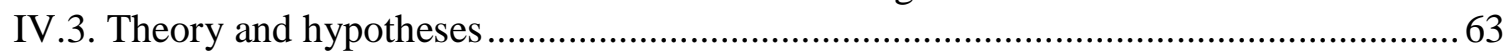

IV.3.1. The first dimension: commercial, financial, and operational motives; time-

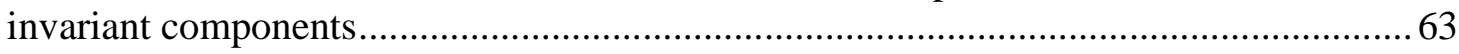

IV.3.2. The second dimension: crisis periods and the time-variant component................65 65

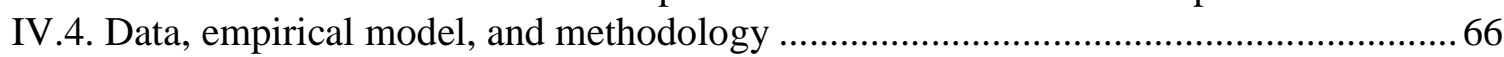

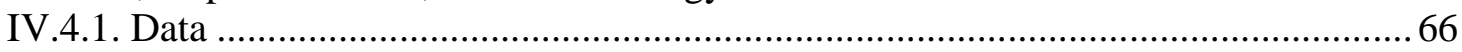

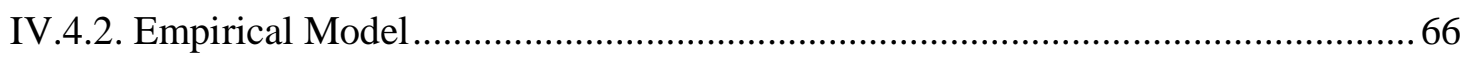

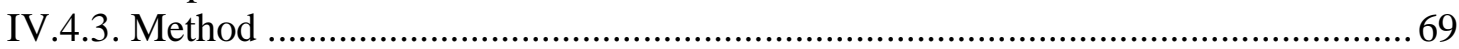

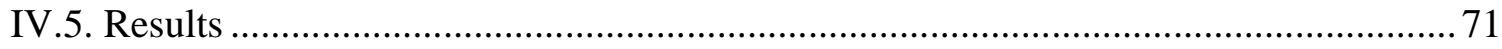

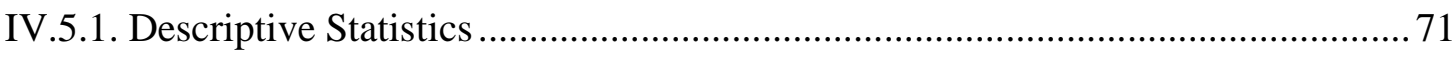

IV.5.2. Testing time-invariant components of trade credit............................................ 71

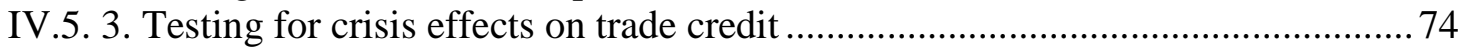

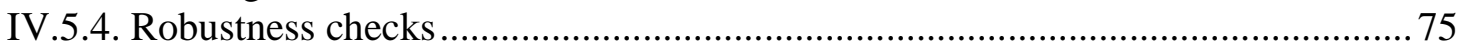

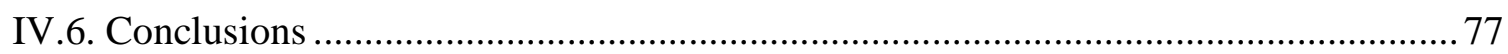

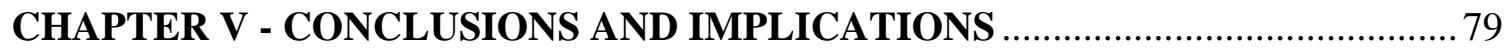

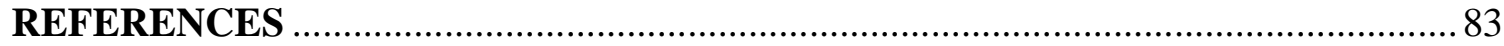




\section{List of Tables}

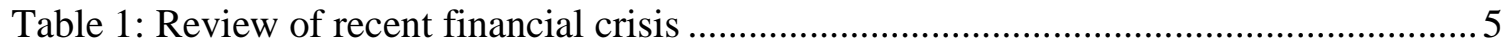

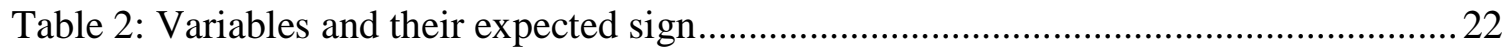

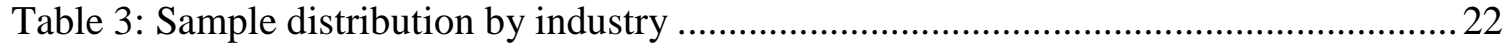

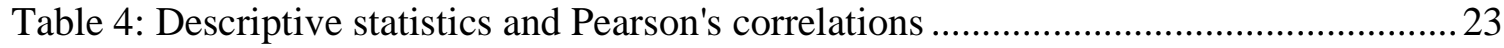

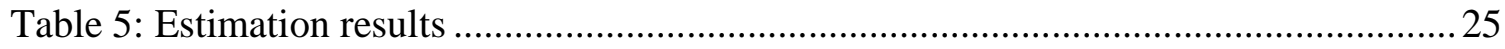

Table 6: Structure of the sample according to creditor protection and accounting standards 45

Table 7: Creditors' rights index and accounting standards index for all countries in the sample....

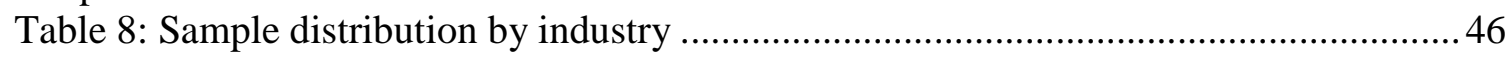

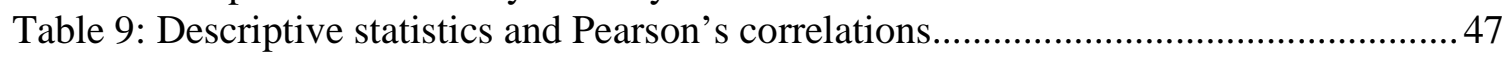

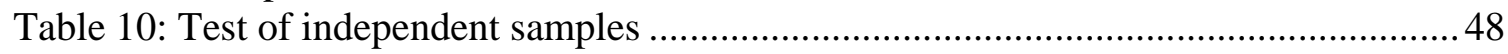

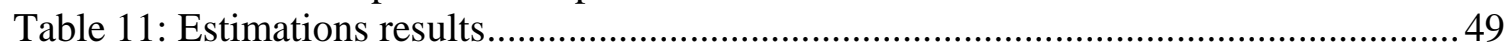

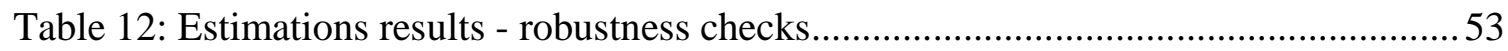

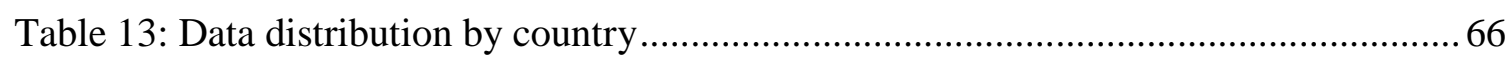

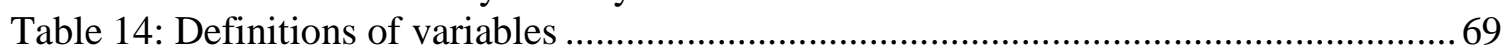

Table 15: Descriptive statistics and Pearson's correlations ................................................. 71

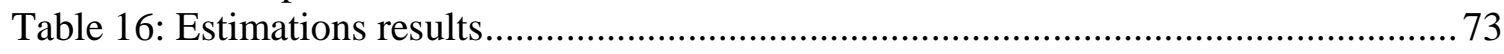

Table 17: Estimations results - robustness checks .......................................................... 76 


\section{List of Figures}

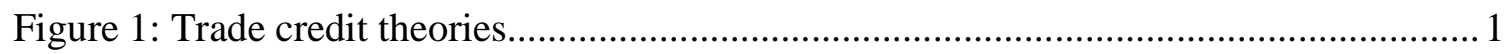

Figure 2: Trade-off between moral hazard and adverse selection and creditor

rights/accounting system influence ..... .39 


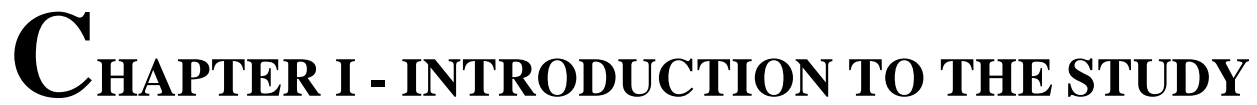

\section{I.1. Introduction}

The objective of this introduction is to afford an overall picture of this study. The arguments presented in this section are offered to show, in the first place, the main motivation for this study and its relevance, as well as a preliminary overview of the broad research on the main determinants of trade credit. In second place, we describe the characteristics of different institutional environments that in our view have an impact on the trade credit extension. Finally, we present our objectives and the structure of the study.

\section{I.2. Motivation for the study and relevance}

Corporate finance decision-making is often split into three different focal points, capital structure, capital budget and working capital. Capital structure has been widely studied by financial scholars and has to do with answering the question: what is the optimal combination of sources of finance? The capital budget decision consists of making the optimal choice from among the different long term investment opportunities faced by a firm. The working capital decision embraces, mainly, cash management, inventory decisions and trade credit policies. The extension of trade credit and its use by firms is the main subject of this thesis.

Trade credit is widely used by firms among different countries around the world. Although its use presents variations among firms from different countries, it represents a high proportion of the firm's assets, sometimes accounting for more than a quarter of them. Its importance as a source of finance by firms triggered the interest of scholars in studying its determinants. Indeed, the question of why firms extend trade credit instead of leaving this function to financial intermediaries should be answered. With the aim of respond this question scholars have sought the main trade credit determinants in different ways. Some of them divided trade credit determinants into financial, operational and commercial types. 
Others have divided them into time-invariant and time-variant determinants. Several studies have focused on trade credit extension, others on trade credit demand. A number of them have concentrated on trade credit in transition economies or in developing countries and quite a few on trade credit during economic crises.

Although all these studies have shed some light on trade credit motivations, we believe that there is still a lack of knowledge about trade credit in the existing literature. Indeed, models used to take in account only one approach in explaining trade credit. According to the financial view, trade credit is extended from firms with widespread access to credit from financial intermediaries to credit constrained firms. Papers based on the transaction costs argument posit that suppliers extend credit to buyers because they have advantages over banks in acquiring information about customers' creditworthiness. Papers supported by commercial arguments argue that firms of unknown reputation must sell on credit to allow clients to access product quality before paying for it. We understand that trade credit may be determined by a trade-off between more than one theory. Indeed, when information between buyers and sellers is asymmetric, trade credit will be extended to allow clients to check the real quality of the product bought. However, in asymmetric information conditions, suppliers may tighten the terms of credit since buyers' creditworthiness is doubtful. Another type of lacuna in trade credit studies concerns the influence of legal aspects such as creditors' protection and accounting systems in trade credit usage. Finally, trade credit practices during economic crises are also little known as is the possibility of trade credit contagion.

\section{I.3. The different environments that have an impact on trade credit supply and demand.}

\section{I.3.1. Legal aspects}

Legal rules vary greatly among countries and influence corporate finance patterns. These legal rules embrace different aspects and are related to the legal origin of a country. According to La Porta et al. (1998), commercial laws are derived from two legal traditions: common law and civil law. The first has its origin in England and the latter derives from 
Roman law. Three major legal families gave rise to modern civil law: French, German and Scandinavian.

La Porta et al. (1998) affirm that the common-law family embodies the law of England and those laws based on English law, that is, the former British colonies such as United States, Canada, Australia, India, and others such as Israel, Kenya, Malaysia, Nigeria, Pakistan, Singapore, South Africa, Sri Lanka, Thailand, Zimbabwe, etc. In addition, they affirm that the French commercial code was written under Napoleon in 1807 and was spread by his army to Belgium, the Netherlands and Italy. It influences Luxembourg, Portugal and Spain and, since Portugal and Spain had had empires since the navigation discovery era, all their colonies were in turn also inspired by French civil law, as is the case of Argentina, Brazil, Chile, Colombia, Ecuador, Mexico, Peru, Uruguay, Venezuela, and so on. Furthermore, they say that the German Commercial Code was written in 1897. This legal tradition was adopted by countries such as Austria, Japan, South Korea, Switzerland, Taiwan, and others. Scandinavian civil law was adopted especially by the Nordic countries, Denmark, Finland, Norway and Sweden.

Some of the differences in legal features among countries include the level of investors' legal protection, the level of creditors' legal protection, the enforcement of laws and the accounting standards. Although all these features may influence financial patterns of firms, we believe that two of them have a particular impact on trade credit usage among firms from different countries: the level of creditors' protection and the level of accounting standards. Following, we present some characteristics of both aspects, and in Chapter 3 we present the study of their influence on the trade credit extended.

The aspects regarding the level of creditors' protection considered in this work follow the analysis made by La Porta et al. (1998) of the general strategies of a creditor dealing with a defaulting firm: liquidation and reorganization. They create a creditor rights index that considers four features: i) when creditor consent is required in the reorganization procedure; ii) when secured creditors are ranked first in the distribution of the proceeds from a bankrupt firm; iii) when, during reorganization, an official is appointed by the creditors or by the judge to be in charge of the operation of the firm, and; iv) when secured creditors can take collateral from firms going through reorganization without waiting for the reorganization to finish. Based on the four aspects described above, La Porta et al. 
(1998) affirm that the legal origin matters in the level of creditor protection. According to them, countries from Common-law systems offer the highest level of creditor protection and countries based on French Civil-law offer the worst.

The influence of the level of creditor protection on trade credit policies has to do with the fact that the trade credit extended is expected to be negatively related to customers' credit risk. As a consequence, in countries with high creditor protection the credit risk is likely to be less strong than in countries of low creditor protection. Although this assumption seems to be obvious, as far as we know it has only been studied for the case of credit extended by financial institutions and has not been tested in the case of trade credit extended from suppliers to customers.

The influence of the accounting standards of a country on the credit extended is related to the useful information for credit analysis provided by accounting statements. The better the accounting systems of a country the clearer the information about firms' financial situation for financial intermediaries. Of course, this outcome is likely to occur in the extension of trade credit too. A good and efficient accounting system mitigates the risk in extending any kind of credit since the information is clear and trustworthy.

Again, the measure for accounting standards used in this work follows La Porta et al. (1998). They use an index constructed in 1991 for 44 countries. According to this paper, Scandinavian-civil-law countries present the highest quality in accounting standards, followed by common-law countries and the German-civil-law countries. The poorest accounting standards among the four legal origins are in those countries whose system stem from French-civil-law.

\section{I.3.2. Economic crises}

In the last 15 years several crises have started spreading uncertainty and, consequently, economic shocks around the world. Table 1 summarizes the main economic shocks from Mexico's crisis in 1994 to the USA's crisis in 2008. As will be explained in Chapter 4, we concentrate our research by analyzing trade credit used during the Argentine crisis of 2001/2002, the Brazilian crisis of 1999 and the Turkish collapse of 2001. In the following paragraphs we present some information about these crises without attempting to make an exhaustive description of the crises. 
Table 1: Review of recent financial crisis

\begin{tabular}{|l|c|c|}
\hline Crisis name & Crisis country & Crisis period \\
\hline Tequila & Mexico & 1994 \\
\hline Asian Flu & Hong Kong or Thailand & 1997 \\
\hline Russian Virus & Russia & 1998 \\
\hline Brazilian crisis & Brazil & 1999 \\
\hline Turkish collapse & Turkey & 2001 \\
\hline Terrorist acts and economic slow down & U.S. & 2001 \\
\hline Argentina crisis & Argentina & 2002 \\
\hline Accounting scandals & U.S. & 2002 \\
\hline Lula's effect & Brazil & $2008 / 2009$ \\
\hline Real Estate Markets & U.S. & \\
\hline
\end{tabular}

Following the Asian crisis of 1997 and the Russian default of 1998, Argentina went through a strong economic crisis in 2001 and 2002 that caused negative growth rates and increased unemployment. Two causes for the Argentine economic crisis have been pointed out by the literature: the devaluation of the Brazilian Real against the Argentine Peso and the persistent deterioration in fiscal revenues. During 2001 there was an increase in the distrust in the Argentine economy and consequently in the government's capability of honoring its debt. The international reserves, which in the beginning of the year corresponded to US\$21 billion dropped to US\$15 billion in August. Undoubtedly, Argentina was going through a serious confidence crisis characterized by the flight of a large amount of capital (Ferrari and Cunha, 2008).

During the year 1999, the Brazilian currency (Real) lost its value by more than $60 \%$, dropping from US\$1.20 in the beginning of January to US\$1.98 at the end of January. Brazilian reserves in dollars decreased $18 \%$, from US $\$ 44$ billion to US\$36 billion during the year, as a consequence of investors' uncertainty about the Brazilian economy and the government effort in defending its currency. The Gross Domestic Product (GDP) increased by just $0.25 \%$ from 1998 to 1999 when it was measured in constant market prices in national currency, but the GDP decreased by $30.47 \%$ when it was measured in US\$ as a consequence of the currency devaluation. The total amount of credit extended to the private sector as a percentage of the GDP presents a smooth decline in 1999 and 2000. However, it was decreasing since 1995 , and it only started to increase in $2005^{1}$. All this information about the Brazilian 1999 economic scenario allows us to suppose the occurrence of trade

\footnotetext{
${ }^{1}$ Source: International Monetary Found
} 
credit contagion and to presume that, in this specific period, the trade credit policies of firms have changed.

The Turkish collapse of 2001 was characterized by a depreciation of $40 \%$ in its currency, the Lira, which as a consequence made repayment of debt in foreign currency difficult for banks and business. According to Akyurek (2006), the crisis harshly damaged the Turkish banking system and caused a contraction in economic activity that had never occurred before. Akyüz and Boratav (2003) affirm that the collapse of the Lira had a hard impact on those sectors with high exposure to exchange rate risks. In addition, public finances were tightening from rising external debt due to the collapse of the currency and the climb in interest rates. Furthermore, the reaction of exports to the sharp devaluation of the currency was delayed because of the interruption of the credit and supply systems.

As described above, the three crises had a severe impact on the supply of credit. This situation may influence the supply of credit from suppliers towards their customers. The lack of available finance from financial intermediaries will certainly cause changes in the finance patterns of firms. Specifically, the way that firms finance their activities will change, which will cause consequences in trade credit supply and demand.

\section{I.4. Objectives and structure of the study}

Trade credits have been widely studied by financial scholars. The question of why firms extend credit to customers instead of focusing on their main activities is one of the causes of the existence of such an extensive body of literature on trade credit. Many others issues have triggered researchers' interest in trade credit study, such as its importance as a mechanism of channeling credit from financial institutions to credit constrained firms, its relevance for start-up firms and its different uses by firms from different countries.

Our research tries to contribute to the solution of some of these issues by showing that the relationship between suppliers and buyers is an agency relationship whose characteristics will determine the trade credit extended, by introducing the level of creditor protection and accounting standards into the analysis and by the analysis of firms from countries that have undergone an economic crisis in recent years. 


\section{A trade credit explanation based on the agency theory, legal factors and credit contagion}

The first objective of this research provides a complement to those theories that propose that trade credit is used to allow clients to check the quality of the product bought before paying for it, as a consequence of ex-ante asymmetric information between suppliers and buyers (Smith, 1987). Starting from this argument, also tested by Lee and Stowe, 1993; Long et al, 1993; Deloof and Jegers, 1996; Wei and Zee, 1997; Pike et al., 2005, we go one step further by introducing an opposite effect of the asymmetric information on the trade credit extended, the moral hazard phenomenon. Since in asymmetric information conditions suppliers are unable to check the real creditworthiness of customers, they will reduce the trade credit extended. Therefore, trade credit policy in conditions of asymmetric information will be a result of a trade-off between the time that buyers require to check the quality of the product before paying for it and the time that suppliers will give them in order to mitigate the risk of buyer default.

The second main objective of this research regards the effect of the institutional environment on the trade credit extended by providers. Specifically, we aim to find the influence of the level of creditor protection and the level of accounting standards on the risk of buyers not making the payment when it is due. The basis of our argument is that in countries with a low level of creditor protection the risk of credit is higher than in countries with a high level of creditor protection. Therefore, suppliers' terms of credit will be influenced by this legal characteristic. Regarding the level of accounting standards, the basis of our argument is that the asymmetric information between suppliers and buyers is mitigated in countries with high quality accounting rules, which reduces credit risk.

The third main objective is to check for empirical evidence of trade credit contagion during economic crises and also for some empirical evidence supporting the substitution hypothesis between trade credit and bank credit. Although several works have tested the financial theory to explain trade credit, often proposing that trade credit acts as a mechanism of credit channelling during monetary contractions or economic uncertainty (Meltzer, 1960; Schwartz, 1974; Nilsen, 2002 and Baum, Caglayan and Ozkan, 2003), there is a lack of knowledge about the effect of economic crises on trade credit demand. To fill this gap, we base our argument on the fact that firms with a high probability of insolvency and high levels of accounts receivable are more likely to be affected by an economic crisis and by credit contagion. 


\section{A trade credit explanation based on the agency theory, legal factors and credit contagion}

It is worth pointing out that all the above-mentioned objectives are connected and that the study of trade credit offer and trade credit demand can find in this thesis a solid basis for future research. With our objectives clearly delimited, we next describe the structure of this work.

This thesis is composed of four chapters beyond this introduction. In each chapter we aim to analyze trade credit offer or trade credit demand determinants by considering different samples of firms, from different countries with different legal systems, levels of creditor protection and accounting standards. We also consider the impact of economic crisis periods in these trade credit determinants.

In the next chapter we study trade credit supply by proposing a model based on the agency theory in which the relationship between suppliers and customers consists of an agency relationship in that two phenomena arise: adverse selection and moral hazard. The former is a problem that occurs when there is ex-ante asymmetric information between suppliers and buyers. In this case, clients do not know ex-ante the quality of the goods they are buying and, as a consequence, will require large terms of credit to assess the quality of the product before paying for it. The latter consists of the possibility of the contractual relationship not being carried out by the client, i.e., the likelihood that payment will not be made when due, since sellers do not know enough about buyers' creditworthiness. Therefore, the proposed model posits that trade credit supply is a result of a tradeoff between both phenomena. Using a sample of manufacturing firms from the United Kingdom comprising four years, 1999 to 2002, we run a fixed-effects model and find that the adverse selection phenomenon is directly related to trade credit extended and that the moral hazard phenomenon is negatively related to trade credit, however only at low levels. The main conclusion of this finding is that, although suppliers tend to tighten terms of credit when the customers' risk increase, their effort will never be enough when this risk becomes too high.

Chapter 3 prolongs the previous analysis but using a sample of firms comprising thirteen countries of different legal origins and consequently different levels of creditor protection and accounting standards. In these analyses we consider the question of how these legal features influence the negative relationship between trade credit extended and moral hazard costs. In this paper we also use the panel data methodology, which allows us 
to control for individual heterogeneity and for the problem of the endogeneity. Results show that high levels of creditor protection and high quality in accounting standards mitigate the negative relationship between trade credit and moral hazard. This occurs because high levels of creditor protection increase suppliers' probability of receiving payment for the goods sold, which reduces moral hazard costs. Furthermore, high quality in accounting standards mitigates information asymmetries between sellers and buyers and consequently diminishes moral hazard costs.

In the Chapter 4, our focus changes to the explanation of trade credit demand during crisis periods. In this study we use a sample of firms from three countries that have recently gone through an economic crisis: Argentina, Brazil and Turkey. Although in the last decade and at the beginning of this one, many other crises have occurred, we had data limitations that have impeded their inclusion in the study. We argue that trade credit presents timevariant and time-invariant determinants. The main results of this chapter as regards timeinvariant determinants are that trade credit received by firms depends on their bargaining power to require large periods of credit from suppliers; the existence of high levels of investment opportunities and the access to credit from financial institutions. As regards time-variant determinants, trade credit depends on the insolvency risk of buyers. If buyers are considered highly vulnerable to an economic and credit contraction resulting from an economic crisis, they will delay payments to suppliers, giving rise to a trade credit contagion effect.

This research culminates with a presentation of the main findings in Chapter 5. These main findings will allow us to defend the thesis proposed in this work in that: "Trade credit demanded and extended by firms is a result of the influence of internal factors (such as the moral hazard, the adverse selection, the bargaining power and the investment opportunities presented by the customer firm) and is also influenced by some external factors that characterize the legal and the economic environment (such as the level of creditor protection, the accounting standards and the economic situation)." 


\section{CHAPTER II - AN AGENCY MODEL TO EXPLAIN TRADE CREDIT POLICY AND EMPIRICAL EVIDENCE}

\section{II.1. Introduction}

Trade credit is a very important source of financing for firms. Although it is an old practice, it is not completely understood. Regarding trade credit, there are two strands of literature. The first focuses on studying the demand for trade credit, which is closely related to lending relationships and lines of credit. The papers in this strand of literature are mainly based on the argument that firms would increase the level of trade credit used when their alternative sources of finance are limited, in that trade credit is an important alternative for short and long term bank debt (see, for instance, Petersen and Rajan, 1994; Petersen and Rajan, 1995; Deloof and Jegers, 1999; Danielson and Scott, 2004; Alphonse et al., 2004; Niskanen and Niskanen, 2006). The second strand of literature studies the supply of trade credit (see, for instance, Long et al., 1993; Deloof and Jegers, 1996; Wei and Zee,1997; Ng et al., 1999; Pike et al, 2005). There are also papers such as that of Petersen and Rajan (1997) and Marotta (2005), which study the trade credit from both points of view. Additionally, Marotta (2005) provides a study that takes into consideration important aspects of trade credit such as cash discounts and penalties for ex post delays. In our paper, we focus on the second strand, since we understand that the seller is the one who decides whether or not to offer trade credit and, consequently, trade credit policy can be better understood by taking this fact into account. This approach refers to the study of either the level of the accounts receivable or the average collection period. According to Long et al. (1993), the average collection period allows us to measure two separate aspects of trade credit: the length of time that the credit is outstanding and the fraction of total sales made on credit.

In this second strand of literature, numerous theories have been proposed to explain the existence and use of trade credit, but none of them can provide a complete explanation of the topic. While some of the models are more consistent in the case of certain industries 
or categories of products, others work better in a financially constrained environment. As far as we know, four types of explanation have been provided by economic literature: i) a theory based on transactions costs arguments (proposed by Schwartz, 1974); ii) a liquidity theory (suggested by Emery, 1984); iii) a tax theory (developed by Brick and Fung, 1984); and iv) a product quality theory (suggested by Smith, 1987).

This paper focuses on explaining trade credit by using an agency model based on an extension of the agency problem described by Jensen and Meckling (1976). We take into consideration the relation between a firm and its clients, an agency relation from which two phenomena arise: adverse selection and moral hazard. An adverse selection problem stems from the ex-ante asymmetric information between buyers and sellers. In this case buyers do not know ex-ante the characteristics and quality of the goods that are being bought. However, a moral hazard problem arises from the ex-post asymmetric information between sellers and buyers, which gives rise to the possibility that clients will not pay when payment is due. Therefore, we argue that trade credit policy is a result of the trade-off between the adverse selection and moral hazard phenomena. Note that other authors (for example, Long et al., 1993) have taken into account the adverse selection phenomenon in explaining trade credit policy, but none of them have considered the moral hazard phenomenon. Consequently, from our point of view, the main contribution of this paper is to show the importance of the moral hazard phenomenon and it suggests that both phenomena together could explain trade credit policy.

According to our argument, we have tested an agency model whose explanatory variables are those that explain the adverse selection and moral hazard phenomena. The empirical evidence is provided from a sample of UK companies, where, according to previous evidence, trade credit is highly relevant and represents more than $62 \%$ of firms' total debt (Bevan and Danbolt, 2002) ${ }^{2}$. Moreover, the estimation methodology used in this paper is panel data in order to control for individual heterogeneity.

The results support our agency model. According to the adverse selection phenomenon, we find that smaller firms, those with a smaller proportion of fixed assets,

\footnotetext{
${ }^{2}$ These authors have made a decompositional analysis of capital structure for UK companies. According to them, determinants of gearing depends on the measure used to proxy it and consequently depend on which component of debt is being analysed. Their evidence shows that results are very sensitive to whether or not trade credit is included.
} 
and those that are less profitable, tend to extend more trade credit. Regarding the moral hazard phenomenon, our empirical evidence reveals that the higher the proportion of variable costs and the higher the percentage of bad debts, the less trade credit offered. Concerning traditional models, our paper finds empirical evidence against tax and transactions costs theories. Furthermore, as in Marotta (2005), our results do not support the liquidity argument that links trade credit and credit rationing.

The remainder of the paper is organized as follows. Section 2 focuses on the theories on trade credit policy. Our agency model explaining trade credit policy is developed in Section 3, and Section 4 describes the data set and methodology used. Section 5 shows our interpretations of the estimation results of our agency model and also tests traditional models. Finally, the conclusions are presented in Section 6.

\section{II.2. Theories on trade credit policy}

Trade credit is one of the oldest forms of corporate financing and it continues to be very important at present; it refers to the financing provided by a seller to the client (Wei and Zee, 1997). To understand the concept of trade credit it is important to know the range of alternative credit arrangements that can occur in trade. Depending on the type of credit policy, payment can be made at different times. It can occur before delivery, on delivery or after delivery. In the last case, the seller may or may not offer discounts for prompt payment, depending on trade arrangements. When payment does not occur before or on delivery, trade credit is being extended and the seller assumes the credit risk. Otherwise, trade credit is not being offered and the buyer assumes the risk that the product may be of low quality.

Although trade credit is a very useful source of resources for different kinds of firms, there is no clear explanation of it yet, as pointed out by Long et al. (1993). In the last three decades, several theories and models have appeared to explain trade credit. Most of these theories rely on market imperfections, such as the existence of taxes, transactions costs and asymmetric information, as shown in Figure 1. 


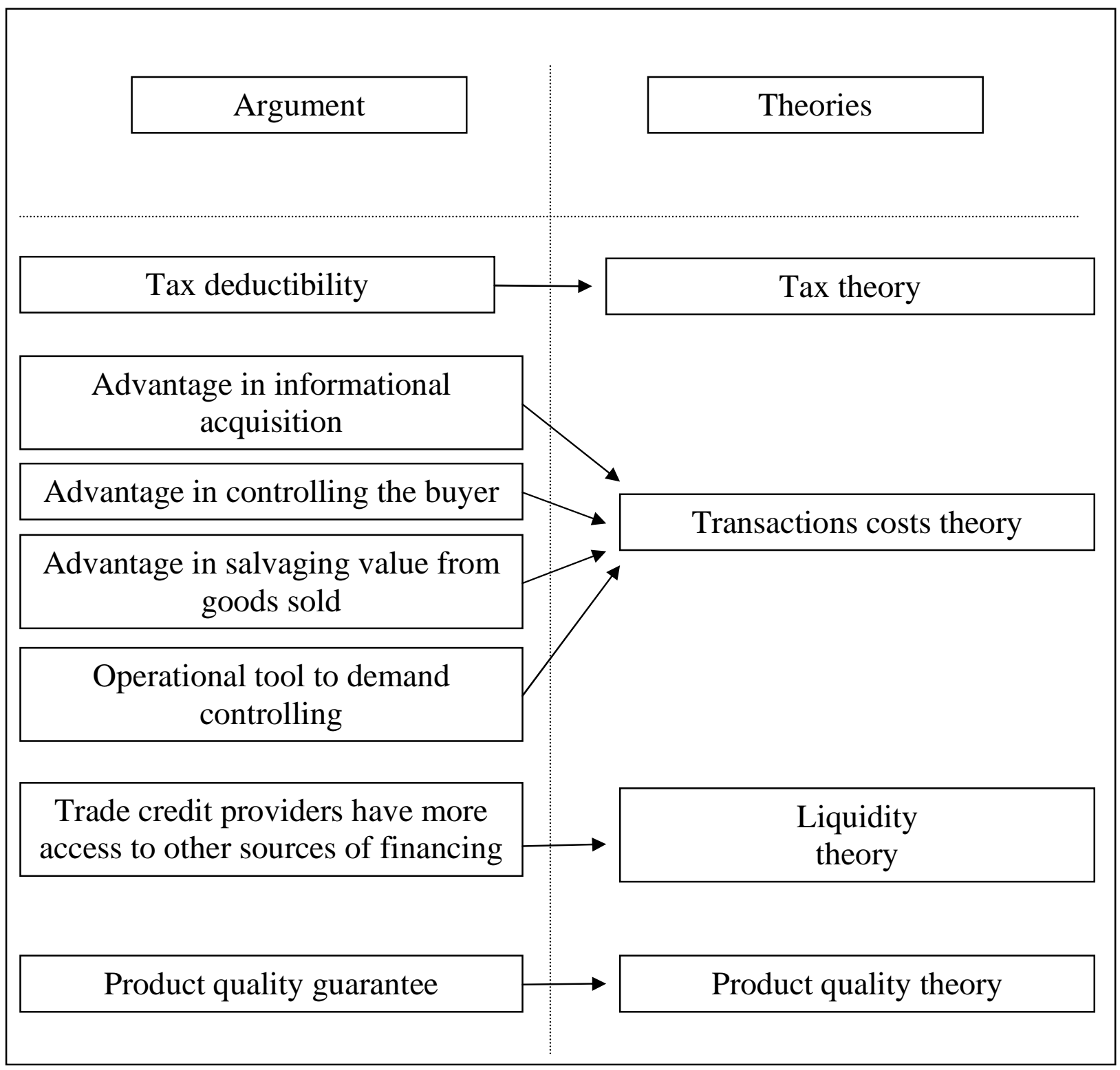

Figure 1: Trade credit theories

\section{II.2.1. Tax theory}

The decision whether or not to accept a trade credit depends on the ability to access other sources of funds. A buyer should compare different financing alternatives to find out which choice is the best. In trade between a seller and a buyer a post payment may be 
offered, but it is not free, there is an implicit interest rate which is included in the final price. Therefore, to find the best source of financing, the buyer should check out the real borrowing cost in other sources of funds.

Brick and Fung (1984) suggest that the tax effect should be considered in order to compare the cost of trade credit with the cost of other financing alternatives. The main reason for this is that if buyers and sellers are in different tax brackets, they have different borrowing costs, since interests are tax deductible. The authors' hypothesis is that firms in a high tax bracket tend to offer more trade credit than those in low tax brackets. Consequently, only buyers in a lower tax bracket than the seller will accept credit, since those in a higher tax bracket could borrow more cheaply directly from a financial institution. Another conclusion is that firms allocated to a given industry and placed in a tax bracket below the industry average cannot profit from offering trade credit. Therefore, Brick and Fung (1984) suggest that firms cannot both use and offer trade credit.

\section{II.2.2. Transactions costs theory}

First developed by Schwartz (1974), this theory conjectures that suppliers may have an advantage over traditional lenders in checking the real financial situation or the credit worthiness of their clients. Suppliers also have a better ability to monitor and force repayment of the credit. All these superiorities may give suppliers a cost advantage when compared with financial institutions. Three sources of cost advantage were classified by Petersen and Rajan (1997) as follows: information acquisition, controlling the buyer and salvaging value from existing assets.

The first source of cost advantage can be explained by the fact that sellers can get information about buyers faster and at lower cost because it is obtained in the normal course of business. That is, the frequency and the amount of the buyer's orders give suppliers an idea of the client's situation; the buyer's rejection of discounts for early payment may serve to alert the supplier of a weakening in the credit-worthiness of the buyer, and sellers usually visit customers more often than financial institutions do. In his model, Smith (1987) concludes that in two-part credit terms with a high interest rate, those buyers that do not choose to take advantage of the discount can be identified as high risks, because they may be having financial difficulties. 
Recently, Burkart and Ellingsen (2004) argued that the suppliers' monitoring advantage applies exclusively to input transactions. They posit that the source of suppliers' advantage is the input transaction itself. According to the authors, an input supplier does not incur in monitoring costs to know that an input transaction has been completed, but other lenders do. The main argument supporting the authors' proposition is the difference between cash and input. While the former is easily diverted, i.e., its use does not maximize lenders' expected return, the latter is not easily diverted and its illiquidity facilitates trade credit.

The second source of cost advantage arises from the power of the seller to threaten buyers. In other words, in some cases there are only a few alternative suppliers for the product needed and, consequently, buyers have very restricted choice. In this case, suppliers can threaten to cut off future supplies if they note a reduction in the chances of repayment. Compared with suppliers, financial institutions do not have the same threatening power. This advantage can become stronger when either the buyers represent only a small part of the supplier's sales or the supplier is part of a network and future community sanctions can be made by a group, which makes this threat much stronger (Kandori, 1992). Empirical evidence supporting this hypothesis can be found in McMillan and Woodruff (1999). Another interesting finding in this strand of literature was provided by Petersen and Rajan (1997), whose empirical results suggest that debtors are less willing to repay a distressed seller. Their argument is that threats of cutting off future supplies made by a supplier with financial problems are not so credible.

The seller's ability to salvage value from existing assets is the third source of cost advantage. In the case of buyer default, the seller can seize the goods that are supplied, of course financial institutions can reclaim the firm's assets as well. The difference between them is that since the firms trading are very often from the same industry, the supplier already has a network to sell the goods and consequently repossessing and resale costs would be lower. Mian and Smith (1992) and Petersen and Rajan (1997) provide two interesting approaches related to this cost advantage. The former obtain evidence supporting the idea that the more durable the goods, the better collateral they provide and the greater the credit offered by the suppliers. The latter point out that the extent to which 


\section{A trade credit explanation based on the agency theory, legal factors and credit contagion}

the customers transform the product is also very important. The less they are transformed, the easier it will be for the supplier to repossess and sell the asset using the same channel.

Another important point refers to the relative value of the goods. $\mathrm{Ng}$ et al. (1999) consider that the value of a product differs between firms and financial institutions; i.e., if a product has more value as collateral to a seller than to a financial institution, the seller may have a cost advantage in recuperating the product and selling it again. In this situation, suppliers tend to offer cheaper credit than financial institutions because of the reduction of the credit risk.

Another paper related to transactions costs is Emery (1987); this author hypothesizes that there is a positive relation between demand variability and credit offered. This hypothesis is based on the following argument. When demand fluctuates, a firm has two traditional reactions (production or price adjustment); however, both are very costly and a better decision could be taken in that the seller could change trade credit terms according to demand. Terms can be relaxed when demand drops and tightened when demand increases. In this case, trade credit can be seen as an operational tool. Long et al. (1993) obtain empirical evidence supporting this hypothesis. Their results show that firms with variable demand extend more trade credit than firms with stable demand.

\section{II.2.3. Liquidity theory}

This theory, first suggested by Emery (1984), proposes that credit rationed firms use more trade credit than those with normal access to financial institutions. The central point of this idea is that when a firm is financially constrained the offer of trade credit can make up for the reduction of the credit offer from financial institutions. In accordance with this view, those firms presenting good liquidity or better access to capital markets can finance those that are credit rationed.

Several approaches have tried to obtain empirical evidence in order to support this assumption. For example, Nielsen (2002), using small firms as a proxy for credit rationed firms, finds that when there is a monetary contraction, small firms react by increasing the amount of trade credit accepted. As financially unconstrained firms are less likely to demand trade credit and more prone to offer it, a negative relation between a buyer's access 
to other sources of financing and trade credit use is expected. Petersen and Rajan (1997) obtained evidence supporting this negative relation.

\section{II.2.4. Product quality theory}

The trade credit relation gives rise to two problems. On the one hand, sellers do not usually know the real credit-worthiness of their buyers and; on the other, buyers do not properly know the quality of the product that is being acquired. To solve the first problem, Smith (1987) suggests a model where sellers offer two-part credit terms because they can recognize potential defaults faster than financial intermediaries. And, as commented in Section 2.2, there are many other arguments supporting the idea that suppliers have cost advantages in acquiring knowledge about a buyer's financial situation. Regarding the second problem, Smith (1987) also claims that with asymmetric information about product quality, sellers offer trade credit to allow buyers to verify product quality before payment.

Other options to reduce the cost of the above-mentioned problem is to offer moneyback guarantees and warranties. Trade credit has some advantages when compared with these two. First, in a case of money-back or warranties, if the seller is not in business any more, the buyer can be damaged. Second, when payment is made at the time of sale, a client who wants to obtain the advantages of the money-back system must try to convince the seller that the quality of the product is not as promised.

As pointed out by Smith (1987), one of the major purposes of trade credit is to allow clients to assess product quality prior to payment; however, this is not true for some categories of product. Therefore, this theory works better in some industries whose product quality is unknown at the moment of purchase. According to this argument, sellers will extend more trade credit when selling products where quality is indefinite at a prior moment and the purchase is not frequent. On the contrary, sellers will extend less trade credit when trading perishable items where acquisition is very frequent.

Many financial scholars have studied trade credit from this point of view (see, for instance, Lee and Stowe, 1993; Long et al, 1993; Deloof and Jegers, 1996; Wei and Zee, 1997; Pike et al., 2005). In summary, the main results of these authors are as follows. i) Small firms tend to offer more trade credit than large firms, since small firms still have to establish their reputation about product quality. ii) Firms with longer production cycles 
prolong their collection period, since they produce high-quality goods. iii) Firms selling products whose quality is difficult to measure extend more trade credit because customers must have enough time to assess quality. iv) Sellers of low quality goods may try to pass them off as high-quality goods. In this case, as the cost of extending trade credit increases, these firms will have less incentive to cheat on the information on quality.

\section{II.2.5. What do these theories not explain?}

Although many theories have attempted, in different ways, to explain the existence of trade credit, they cannot provide a complete explanation of the topic. While some of the models are more consistent with the case of certain industries or categories of products, others work better in a financially constrained environment. According to Frank and Maksimovic (1998) "the existing theories show effects that may be important in specific circumstances, but they do not capture what seems to be central for explaining the widespread use of trade credit and the empirical patterns of its use”. Let us check theory by theory and identify some inconsistencies or situations that are not very well explained.

The tax theory suggests that firms in high tax brackets tend to offer credit to those in low tax brackets. Some research studies have found empirical evidence to support this, but this explanation does not seem to be enough since it cannot explain trade credit between firms situated in the same tax bracket.

If trade credit is an operational tool and exists to minimize transactions costs, as Ferris (1981) suggested, a reduction in the level of trade credit used would be expected since many improvements in transaction technologies have taken place. However, this reduction has not been observed in recent years.

The liquidity theory supposes that credit constrained firms use more trade credit than those with easier access to financial intermediaries. This may be an explanation, but once more, it does not seem to be enough since it does not explain why financially unconstrained firms also use trade credit.

The product quality theory argues that trade credit is offered to allow clients to check the real quality of the goods before payment, but it does not explain why firms selling some products and services do not offer credit at all; some firms even require clients to pay in advance. 


\section{II.3. An agency model explaining trade credit policy}

The main difference between our agency model and other models that attempt to explain trade credit by assuming the existence of asymmetric information is the inclusion of the moral hazard phenomenon into our model. According to Jensen and Meckling (1976) the agency problem could be extended to the relation between a firm and its clients. This agency relation is characterized by two phenomena: adverse selection and moral hazard. Adverse selection occurs when there is ex-ante asymmetric information between sellers and buyers. In this case, clients do not know ex-ante the characteristics and quality of the goods that are being acquired. As described in Section 2.4, this phenomenon has already been studied by other authors, but not moral hazard, which consists of the possibility of the contractual relationship not being carried out by the client, facilitated by the ex-post asymmetric information. This phenomenon has an important consequence in that it could lead to clients not paying for the goods bought when the payment is due, giving rise to bad debts. Consequently, we define a function to explain trade credit as follows: $\mathrm{DSO}=\phi(\varpi, \mu)$, where DSO is the day of sales outstanding, $\bar{\omega}$ stands for the agency costs arising from the adverse selection phenomenon, while $\mu$ represents the agency costs caused by the moral hazard phenomenon. According to our model, the greater the adverse selection costs the more trade credit provided to clients. In addition, the greater the moral hazard costs the less the trade credit offered to clients. Therefore, we expect $\varpi$ to be positively related to DSO and $\mu$ to be negatively related. Consequently, our model explains the days of sales outstanding (DSO), which is measured as the natural logarithm of the accounts receivable divided by daily sales.

The literature has argued that several variables should be taken into account to proxy the adverse selection phenomenon. First, the goods sold by technical industries need a significant amount of time to verify their quality level, hence a high adverse selection cost is associated with these goods. To classify each firm in our sample as part of the technical industry or not, we follow Titman and Wessels (1988), defining technical industries as those in SIC codes between 3400 and 3999. Other authors that have used the same classification include Long et al. (1993). Additionally, there are no adverse selection costs when buying some products which are easy to observe (perishable). Following Long et al. 
(1993), we consider perishable products to be those sold by firms in SIC codes between 2000 and 2199. Therefore, we have constructed the Product Quality Level variable (PQL) in order to measure the product quality level combining these two characteristics. We also base the construction of the product quality level variable, PQL, on the argument that if the reputation of the firm selling the product is already known, as is the case of large firms, less time is needed to verify the quality. Therefore, the PQL variable takes into account both the kind of product and the size of the firm. This variable takes higher values when the period needed to verify the quality of the product is longer, and vice versa ${ }^{3}$. As a result, the product quality level should be positively related to DSO. Second, the firm's reputation considerably reduces the adverse selection costs. The firm's reputation is proxied by the variable SIZE, measured as the natural logarithm of a firm's total assets. The expected relationship between DSO and SIZE is negative. Third, Prowse (1990) argues that the greater the proportion of fixed assets in a firm, the smaller the asymmetric information problem. Following Prowse (1990), we compute the variable fixed assets, FIX, as 1-(Fixed Assets/Total Assets). This variable provides a measure that is inverse to the fixed assets of a firm; hence we expect FIX to be directly related to DSO. Fourth, the negative consequences of the problem of adverse selection to the buyer are mitigated by the supplier's profitability. To proxy for supplier's profitability we use the return on assets variable (ROA), calculated as earnings before interest and taxes divided by total assets. This variable is expected to be negatively correlated to DSO. Fifth, the last variable we use to proxy the adverse selection is the days to pay accounts payable (DPA), calculated as in Compustat Global Vantage as follows: accounts payable times 360 divided by the sum of inventories plus cost of goods sold plus depreciation and amortization minus the previous value for inventories minus depreciation and amortization. This variable is entered into the model because high quality firms are prone to increase the trade credit offered to their clients, and they use this argument to require more trade credit from their suppliers. Therefore, the expected relation between days to pay accounts payable and DSO is positive.

\footnotetext{
3 We calculate the $\mathrm{PQL}$ variable as follows: $\mathrm{PQL}=(30 /(1+\mathrm{SIZE}))$ for technical industries, $\mathrm{PQL}=(0.5 /(1+\mathrm{SIZE}))$ for perishable industries, and $\mathrm{PQL}=(2 /(1+\mathrm{SIZE}))$ for the remaining firms. The figures 30,2 and 0.5 have been chosen in order to give more power to the first characteristic related to industry, as suggested in financial literature. However, note that the second characteristic (size) plays an important role, since it distributes the values within each kind of industry and provides variability to PQL, which is necessary when using panel data methodology. More details will be provided by the authors upon request.
} 
We base our variables to proxy the moral hazard phenomenon on Oh (1976). In accordance with this author, the decision to change a current credit policy to a new one depends on whether the marginal profitability is greater than the associated marginal opportunity cost. Therefore, when a firm decides to extend its credit policy it is probably expecting a sales increase and, hence, the firm is prepared to assume new costs such as collection costs, bad debt losses and variable costs. Thus, the credit policy decision involves a tradeoff between profits from marginal sales and their marginal costs.

According to trade credit literature, the more extensive the credit offered, the greater the amount of bad debt losses the seller will support. To mitigate this problem, firms are motivated to offer bigger cash payment discounts. Marotta (2005) argues that there is a strong relation between cash discounts and debt periods, specifically when creditors' rights protection is more effective. These discounts must be attractive enough to convince even the risky buyer to pay sooner, because if they do, it may reduce the possibility of bad debt losses inasmuch as it restricts the amount of time available to buyers to develop more problems. We proxy this problem (the cost of bad debt that may arise when trade credit is extended) by using the bad debt provision variable (BDP). This variable is calculated as the Provision-other item from Compustat Global Vantage divided by total assets. Consequently, the expected relationship between bad debts provision and DSO is negative.

When trade credit is extended, if the buyer does not pay, the supplier will support all costs generated by the sales. Therefore, the damage caused by the moral hazard problem will be greater the higher the percentage of variable costs of the goods sold. As a result, we expect that the greater the variable costs, the more rigid the credit policy will be. Consequently, an additional variable to proxy the extent of the moral hazard problem is the variable costs variable (VCO), calculated as the cost of goods sold divided by total assets. Therefore, a negative relationship between the variable costs and DSO is expected.

To test the expected relation between trade credit policy and both phenomena, we propose an agency model incorporating all the variables that we have considered as characterizing the adverse selection and moral hazard problems. This model would be as follows:

$$
D S O_{i t}=\beta_{0}+\beta_{1} V C O_{i t}+\beta_{2} B D P_{i t}+\beta_{3} P Q L_{i t}+\beta_{4} S I Z E_{i t}+\beta_{5} F I X+\beta_{6} R O A_{i t}+\beta_{7} D P A_{i t}+\varepsilon_{i t}
$$


The explanatory variables and their expected sign according to our previous argument are displayed in Table 2.

Table 2: Variables and their expected sign

\begin{tabular}{ccc}
\hline Phenomenon & Variables & Expected Sign \\
\hline Adverse Selection & Product quality level (PQL) & + \\
Adverse Selection & Size (SIZE) & - \\
Adverse Selection & Return on assets (ROA) & - \\
Adverse Selection & Fixed assets (FIX) & + \\
Adverse Selection & Days to pay accounts payable (DPA) & + \\
Moral Hazard & Variable costs (VCO) & - \\
Moral Hazard & Bad debts provision (BDP) & - \\
\hline This table contains all the explanatory variables entered into our agency model and their expected sign.
\end{tabular}

\section{II.4. Data and methodology}

We decided to restrict our sample to manufacturing firms because it is in this category where trade credit takes place in its habitual form. Consequently, our sample covers active manufacturing companies in the UK (SIC 2000 through 3999) from the Compustat Global Vantage database for a four-year period ending in 2002. As a result, we have obtained an unbalanced panel comprising 336 companies and 1,162 observations. The observations in our sample are industry dispersed, i.e., the sample does not appear to be more concentrated in any industry. Table 3 shows the distribution by industry for our sample.

Table 3: Sample distribution by industry

\begin{tabular}{clcc}
\hline SIC & \multicolumn{1}{c}{ Industry } & Number & $\%$ \\
\hline 20 & Food and Kindred Products & 98 & 8.43 \\
21 & Tobacco Products & 9 & 0.77 \\
22 & Textile Mill Products & 38 & 3.27 \\
& Apparel and Other Finished Products Made from Fabrics and & 42 & 3.61 \\
23 & Similar Materials & & \\
25 & Furniture and Fixtures & 24 & 2.07 \\
26 & Paper and Allied Products & 38 & 3.27 \\
27 & Printing, Publishing, and Allied Industries & 92 & 7.92 \\
28 & Chemicals and Allied Products & 131 & 11.27 \\
29 & Petroleum Refining and Related Industries & 8 & 0.69 \\
30 & Rubber and Miscellaneous Plastic Products & 44 & 3.79
\end{tabular}


31 Leather and Leather Products

$10 \quad 0.86$

32 Stone, Clay, Glass, and Concrete Products $\quad 72 \quad 6.20$

$\begin{array}{llll}33 & \text { Primary Metal Industries } & 32 & 2.75\end{array}$

Manufactured Metal Products, Except Machinery and Transport $\quad 33 \quad 2.84$

34 Equipment

35 Industrial and Commercial Machinery and Computer Equipment $\quad 110 \quad 9.47$

Electronic and Other Electrical Equipment and Components, Except $\quad 170 \quad 14.63$

36 Computer Equipment

$\begin{array}{lllll}37 & \text { Transport Equipment } & 68 & 5.85\end{array}$

Measuring, Analyzing, and Controlling Instruments; Photographic, $\quad 103 \quad 8.86$

38 Medical and Optical Goods; Watches and Clocks

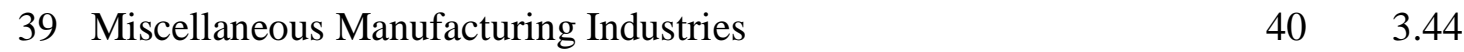

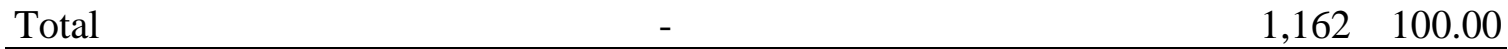

This table shows the distribution by industry for the 1,162 observations.

Summary statistics for the variables used in our analysis and Pearson's correlations are in Table 4. The days of sales outstanding (DSO) is around 70 days. Note that correlation coefficients are moderate and do not violate the assumption of independence between explanatory variables.

Table 4: Descriptive statistics and Pearson's correlations

\begin{tabular}{lcccrrrrrrrr}
\hline & Mean & S. Deviation & Median & \multicolumn{1}{c}{ LNDSO } & VCO & BDP & PQL & SIZE & FIX & ROA & DPA \\
\hline DSO & 4.246 & 0.569 & 4.265 & 1.000 & & & & & & & \\
VCO & 0.616 & 0.552 & 0.575 & -0.248 & 1.000 & & & & & & \\
BDP & 0.018 & 0.054 & 0.002 & 0.316 & -0.018 & 1.000 & & & & & \\
PQL & 2.751 & 3.023 & 0.484 & 0.225 & 0.000 & -0.030 & 1.000 & & & & \\
SIZE & 5.212 & 2.034 & 4.809 & -0.127 & -0.195 & 0.262 & -0.424 & 1.000 & & & \\
FIX & 0.424 & 0.340 & 0.445 & 0.255 & -0.090 & 0.060 & 0.187 & 0.023 & 1.000 & & \\
ROA & 0.012 & 0.326 & 0.072 & -0.173 & -0.040 & -0.049 & -0.101 & 0.206 & 0.002 & 1.000 & \\
DPA & 15.393 & $5,323.1$ & 0.412 & -0.001 & -0.003 & 0.001 & 0.009 & -0.007 & -0.002 & -0.011 & 1.000 \\
\hline
\end{tabular}

This table provides the mean, the standard deviation, the median, and the Pearson's correlations for the 1,162 observations. DSO denotes the natural logarithm of days of sales outstanding, VCO is the cost of goods sold divided by total assets, BDP stands for the bad debt provision divided by total assets, PQL denotes the product quality level, SIZE is the natural logarithm of total assets, FIX is the fixed assets proportion of total assets, ROA stands for the return on assets, and DPA denotes the days to pay accounts payable.

To test the hypotheses related to the proposed model, we use panel data methodology because, unlike cross-sectional analysis, it allows us to control for individual heterogeneity. This heterogeneity could lead us to biased results (see, for instance, Moulton, 1986, 1987). 
Therefore, in our paper we control for heterogeneity by modelling it as an individual effect, $\eta_{\mathrm{i}}$. Consequently our model in Equation 1 would be as follows:

$D S Q_{t t}=\beta_{0}+\beta_{1} V C O_{t t}+\beta_{2} B D P_{i t}+\beta_{3} P Q L_{t t}+\beta_{4} S I Z E_{t t}+\beta_{5} F I X+\beta_{6} R O A_{t t}+\beta_{7} D P A_{t t}+\eta_{i}+v_{i t}$

where $v_{i t}$ is a random disturbance. As a result of the possible correlation between the individual effect and the explanatory variables, we have estimated the model by using the fixed effects estimator, since this estimator is unbiased even if the above-mentioned correlation is present.

\section{II.5. Results}

\section{II.5.1. Estimation results of the agency model}

Table 5 (see column I) provides the results from estimating the model in Equation (2). Our findings show evidence supporting the hypothesis that the greater the adverse selection problem the more trade credit offered. The SIZE variable is negatively related to DSO, which is in agreement with the adverse selection phenomenon, related to the product quality guarantee argument. As a result, smaller firms, with their reputation not yet built, extend more trade credit to allow clients to check product quality and build their status as high quality firms. The FIX variable reveals additional support to the abovementioned hypothesis since there is a positive relationship between FIX and DSO. According to the construction of the variable, the greater its value, the smaller the proportion of fixed assets of a firm. Thus, trade relations between buyers and suppliers with a high proportion of fixed assets suffer from smaller problems of adverse selection, which facilitate the extension of trade credit. The ROA variable is negatively related to DSO. This relationship implies that the more firms earn, the less credit offered. These results support the product quality argument in that the greater the seller's profitability the smaller the adverse selection problem suffered by buyers, and consequently the less trade credit required by them ${ }^{4}$.

\footnotetext{
${ }^{4}$ The above-mentioned variables related to the adverse selection phenomenon show the expected relationships with the dependent variable; however, the PQL and DPA variables are not significant. Therefore, results from regressions do not allow us to affirm that firms categorized as high tech producers extend more credit than
} 
Table 5: Estimation results

\begin{tabular}{|c|c|c|c|c|c|}
\hline Explanatory Variables & (I) & (II) & (III) & (IV) & $(\mathrm{V})$ \\
\hline $\mathrm{BDP}_{\text {it }}$ & $\begin{array}{l}1.145^{*} \\
(3.54)\end{array}$ & $\begin{array}{c}-4.326 * * \\
(-2.15)\end{array}$ & & & \\
\hline $\mathrm{DBDP}_{\mathrm{it}} * \mathrm{BDP}_{\mathrm{it}}$ & & $\begin{array}{l}5.401^{*} \\
(2.76)\end{array}$ & & & \\
\hline $\mathrm{VCO}_{\text {it }}$ & $\begin{array}{l}-0.455^{*} \\
(-10.89)\end{array}$ & $\begin{array}{l}-0.460^{*} \\
(-11.04)\end{array}$ & & & \\
\hline $\mathrm{ROA}_{\mathrm{it}}$ & $\begin{array}{c}-0.083^{*} \\
(-2.91)\end{array}$ & $\begin{array}{c}-0.084 * \\
(-2.95)\end{array}$ & $\begin{array}{c}-0.067 * \\
(-2.32)\end{array}$ & $\begin{array}{l}-0.047 \\
(-1.57)\end{array}$ & $\begin{array}{c}-0.087 * \\
(-2.89)\end{array}$ \\
\hline $\mathrm{TD}_{\mathrm{it}}$ & & & $\begin{array}{l}-0.112 \\
(-1.14)\end{array}$ & & \\
\hline SIZE $_{\text {it }}$ & $\begin{array}{c}-0.149 * \\
(-5.60)\end{array}$ & $\begin{array}{c}-0.149 * \\
(-5.63)\end{array}$ & & $\begin{array}{c}-0.037 * * * \\
(-1.66)\end{array}$ & $\begin{array}{c}-0.073^{*} \\
(-2.64)\end{array}$ \\
\hline $\mathrm{DPA}_{\text {it }}$ & $\begin{array}{c}-9.14 \mathrm{e}-07 \\
(-0.87)\end{array}$ & $\begin{array}{c}-9.20 \mathrm{e}-07 \\
(-0.88)\end{array}$ & & $\begin{array}{c}-9.48 \mathrm{e}-07 \\
(-0.83)\end{array}$ & $\begin{array}{c}-8.27 \mathrm{e}-07 \\
(-0.73)\end{array}$ \\
\hline $\mathrm{PQL}_{\text {it }}$ & $\begin{array}{l}-0.025 \\
(-1.41)\end{array}$ & $\begin{array}{l}-0.024 \\
(-1.33)\end{array}$ & & & $\begin{array}{l}-0.018 \\
(-0.92)\end{array}$ \\
\hline FIX $_{\text {it }}$ & $\begin{array}{c}0.275^{*} \\
(4.82)\end{array}$ & $\begin{array}{c}0.273^{*} \\
(4.79)\end{array}$ & & & $\begin{array}{c}0.329^{*} \\
(5.42)\end{array}$ \\
\hline Const. & $\begin{array}{l}5.237^{*} \\
(29.44)\end{array}$ & $\begin{array}{l}5.250^{*} \\
(29.62)\end{array}$ & $\begin{array}{c}4.270 * \\
(201.45)\end{array}$ & $\begin{array}{l}4.442^{*} \\
(37.94)\end{array}$ & $\begin{array}{l}4.535^{*} \\
(25.60)\end{array}$ \\
\hline $\mathrm{R}^{2}$ - within & 0.166 & 0.174 & 0.007 & 0.010 & 0.044 \\
\hline $\mathrm{R}^{2}$ - between & 0.126 & 0.126 & 0.033 & 0.023 & 0.040 \\
\hline $\mathrm{R}^{2}$ - overall & 0.144 & 0.144 & 0.038 & 0.023 & 0.054 \\
\hline $\mathrm{F}$ & 23.41 & 21.60 & 3.00 & 2.71 & 7.62 \\
\hline
\end{tabular}

The dependent variable is the natural logarithm of days of sales outstanding, and the details about the independent variables are in Table 4. The rest of the information needed to read this table is: $i$ ) Standard error in parentheses; ii) *,** and *** indicate significance at the $1 \%, 5 \%$ and $10 \%$ level, respectively.

Regarding the moral hazard phenomenon, the regression results are partially in accordance with the arguments presented in Section 3. First, we have found that VCO is negatively related to DSO. Therefore, variable costs negatively influence the length of the trade credit extended, because sellers with a high level of variable costs will be more strongly affected in case of buyer default than those with lower levels and, consequently, they will extend less credit. Second, the unexpected positive coefficient for the BDP variable could be related to the distress situation of risky clients. Our argument to explain this result is that firms whose clients are considered "high risk", i.e. those presenting high 
levels of BDP, should raise the cash discounts offered in order to encourage risky clients to pay early and thus avoid bad debts. Unfortunately, these risky clients cannot make use of the discounts offered probably because of their distress situation and then they pay the total value on the net date. Note that this argument is similar to that provided by Fazzari et al. (2000) to explain the very different results obtained by Kaplan and Zingales (1997) when using a subsample of those firms facing a distress situation in the sample corresponding to the Fazzari et al. (1988) seminar paper. Additionally, Pindado et al. (2006) show that when firms face a distress situation they lose their normal patterns of behavior. Our argument also complements Marotta's (2005), who argues that the effectiveness of the decision to offer cash discounts in order to diminish credit periods will depend on the existence of penalties for ex post delays and on the extent to which they are enforced. We add that the success of this decision will also depend on the financial situation of the client.

To distinguish between the firms whose clients are distressed firms from the others, we have constructed a dummy variable, DBDP, that takes the value of 1 if the bad debt provision of the firm is higher than the mean and zero otherwise. We have then interacted this dummy variable with the BDP variable and incorporated this term into the model. Therefore, the new model would be as follows:

$$
D S Q_{t}=\beta_{0}+\beta_{1} V C Q_{t t}+\left(\beta_{2}+\gamma_{1} D B D t_{t}\right) B D P_{t t}+\beta_{3} P Q L_{t t}+\beta_{4} S I Z E_{t t}+\beta_{5} F I X+\beta_{6} R O A_{i t}+\beta_{7} D P A+\eta_{i}+v_{i t}
$$

This new model, whose results are provided in Table 5 (see column II), allows us to test the negative relation expected between trade credit and moral hazard, controlling for the distress situation of the clients. Regarding the BDP variable, the results indicate two different facts. First, when the firm has a bad debt provision higher than the mean, the dummy variable takes the value of 1 and, consequently, the coefficient is $\beta_{2}+\gamma_{1}$. We have performed a linear restriction test whose null hypothesis is $\mathrm{H}_{0}=\beta_{2}+\gamma_{1}$ in order to know if the coefficient $\beta_{2}+\gamma_{1}=1.0772$ is significantly different from zero. As the t-value is 3.3346, we can reject the null hypothesis and conclude that the coefficient is significantly different from zero. This result supports our explanation that when clients present a very high level of risk, seller's efforts to diminish the average collection period are never enough and, in this case, a positive relation between trade credit and bad debt provision arises. Second, when the firm has a bad debt provision lower than the mean, the dummy variable takes the value of zero and the coefficient is $\beta_{2}=-4.3698$. Therefore, when controlling for the 
distress situation the bad debt provision is negatively related to DSO. This result added to the negative relationship found between the variable costs and DSO supports that the greater the moral hazard problem, the less trade credit offered.

Note that the results provided in column II show the same results on the adverse selection phenomenon as those commented above. As a result, we conclude that trade credit policy is explained by a trade-off between the adverse selection and moral hazard phenomena. Therefore, these findings support our model based on agency theory.

\section{II.5.2. Estimation results of the traditional models}

As a robustness check for our model, we test the alternative models described in financial literature. The results show that our model works better in explaining trade credit policy than the traditional models. Specifically, the results do not support the tax, liquidity and transactions costs theories. Furthermore, the results only partially support the product quality theory.

To test the tax argument, we use the total debt variable, $\mathrm{TD}^{5}$. The idea behind this theory is as follows: if sellers have a high level of debt, they are less likely to obtain another loan with tax deductible interest which would reduce the cost of borrowing. Therefore, we expect the total debt variable to be negatively related to DSO. This model also includes profitability (ROA) as an independent variable, since the interest cannot be tax deductible if the seller does not obtain positive earnings before taxes. Our findings (see column III of Table 5) show that only the ROA variable is significant. Therefore, this result does not support the tax theory, showing that trade credit policy cannot be explained by tax motives.

According to the liquidity theory, the DSO is expected to be directly related to the size (SIZE) and profitability (ROA) variables, and inversely related to the days to pay accounts payable variable (DPA). As can be seen in column IV of Table 5, our findings do not support the liquidity theory, since the ROA and DPA variables show non-significant coefficients and SIZE is negatively related to the dependent variable.

\footnotetext{
${ }^{5}$ This variable is calculated as the sum of long term debt and debt in current liabilities as a percentage of total assets.
} 


\section{A trade credit explanation based on the agency theory, legal factors and credit contagion}

To test the operational argument of transactions costs theory, we regress the DSO using as the explanatory variable SDS (standard deviation of sales). As this variable is constructed by using the standard deviation of total revenue over the four-year period ending in 2002, we only have cross-sectional data. Therefore, we use the ordinary least squares method to estimate the model, since it was not possible to use panel data methodology. This theory predicts that DSO is positively related to SDS. The results (provided by the authors upon request) reveal that the coefficient of the variable SDS is not significant; hence the operational argument of the transactions costs theory is not supported.

The product quality theory is tested by using the same explanatory variables incorporated in the agency model to proxy the adverse selection phenomenon. The results (see column V of Table 5) are similar, in terms of sign and significance of coefficients, to those obtained when testing our agency model for the variables capturing the adverse selection phenomenon.

Furthermore, the specification tests could also help us to compare our agency model with the traditional model. Except for the product quality model, the F statistic shows that the null hypothesis that all variables are jointly equal to zero cannot be rejected; therefore these models do not offer a good explanation of the trade credit policy. Although the $\mathrm{F}$ statistic for the product quality model allows us to reject the null hypothesis, the explanatory power of this model is lower than that of our agency model, as can be seen if we compare the values for the $\mathrm{R}^{2}$ between displayed in Table 5 . Note that by using panel data methodology the $\mathrm{R}^{2}$ between is the directly relevant measure of goodness of fit. This greater explanatory power is due to the fact that the product quality model does not include the moral hazard phenomenon, thus providing a limited explanation of trade credit policy, since the risk of buyers not paying when payment is due is crucial when making trade credit decisions.

\section{II.6. Conclusions}

This paper proposes an agency model to explain trade credit offered by firms. This model is based on the two phenomena (adverse selection and moral hazard) arising from 
the agency relation between sellers and buyers. According to our argument, firms make their decisions related to trade credit by taking into account the trade-off between adverse selection (since clients do not know the characteristics and quality of the goods bought) and moral hazard (in that the buyer might not pay for the goods bought when the payment is due).

Our findings strongly support our model to explain trade credit policy. Additionally, our results show that our model works better at explaining trade credit policy than the traditional models. In fact, our results do not support the tax, liquidity and transactions costs theories, while the product quality theory is only partially supported. Therefore, a model accounting for both adverse selection and moral hazard phenomena is needed in order to properly explain how firms make their trade credit decisions. First, the adverse selection phenomenon explains why sellers need to offer trade credit to buyers in order to mitigate the ex-ante asymmetric information caused by the unknown characteristics and quality of the goods bought. Therefore, smaller firms, those with a smaller proportion of fixed assets, and those that are less profitable tend to extend more trade credit in order to mitigate the adverse selection problem. Second, the moral hazard phenomenon explains why some firms do not offer trade credit in order to avoid the negative consequences arising when the clients do not pay for the goods bought. Therefore, the higher the proportion of variable costs the less trade credit offered since the consequences of the moral hazard phenomenon would be more negative. Additionally, the higher percentage of bad debts a firm has, the less trade credit offered in order to encourage their clients to pay when payment is due. 


\section{CHAPTER III - TRADE CREDIT, CREDITOR PROTECTION AND ACCOUNTING STANDARDS: EVIDENCE FROM AN INTERNATIONAL SAMPLE}

\section{III.1. Introduction}

Many previous studies have investigated the use and the offer of trade credit by firms. In most of these papers, scholars were concerned only with firm specific determinants and rarely tried to find cross country differences that may cause variations in trade credit policies among firms located in different countries.

Although some works have recently studied trade credit using samples composed of firms from different countries (see, for instance, Wei and Zee, 1997; Demirgüç-Kunt and Maksimovic, 2001; Fisman and Love, 2003; Delannay and Weill, 2004; Pike et al., 2005; and Horen, 2005), none of them have attended to the specific importance of the creditor protection level as a factor that may mitigate supplier risk in extending trade credit. In addition, as far as we know, the quality of the accounting standards of a country have/has not been studied as a characteristic that diminishes information asymmetries between suppliers and their clients.

In this vein, Wei and Zee (1997) test for the validity of the product quality theory for Germany, Japan, the United Kingdom and the United States. Demirgüç-Kunt and Maksimovic (2001), using a large sample of firms from 39 countries, find that the development of a country's banking system and legal infrastructure predicts the use of trade credit. Fisman and Love (2003) study the relation between industry growth, the development of financial intermediaries and trade credit. However, their work focuses on industry growth instead of on trade credit policies. Additionally, Delannay and Weill (2004) study the determinants of trade credit and trade debt for a large sample of firms from nine Central and Eastern European Countries. Their results did not show generalized determinants of trade credit in all transition countries. Recently, Pike et al. (2005) analyze, for US, UK and Australian firms, whether the twin objectives of reducing information asymmetries and discriminatory pricing are relevant to the definitions of trade credit terms. 
In another relevant paper, Horen (2005) tests for the use of trade credit as a competitiveness tool using a sample of firms from 42 developing countries.

Although the relation between legal framework and trade credit has been little studied, the association between legal infrastructure and bank credit has been deeply explored by scholars (see, for example, La Porta et al., 1998; Galindo and Micco, 2007; Djankov et al., 2007 and, Safavian and Sharma, 2007). These studies have concentrated on bank credit, usually measured by private credit/GDP, and usually, but not always, analyzing country level data. However, the association between this legal infrastructure and trade credit is still little explored.

Differences in countries' legal systems can be proxied by features such as creditors' rights, investors' rights, laws enforcement, accounting standards, etc. Creditor protection varies strongly around the world. According to La Porta et al. (1998) common-law countries offer creditors the strongest legal protection against managers, followed by countries from German-civil-law tradition and Scandinavian tradition. French-civil-law countries offer creditors the weakest protection. The level of creditors' legal protection is determinant for the size of credit markets (see, Galindo and Micco, 2007), since the borrowing risk increases in countries where creditor protection is low. Generalizing this proposition, it can be affirmed that the level of creditors' legal protection will also affect the risk involved in extending trade credit to a client.

As occurs in the case of creditor rights, the quality of the accounting standards varies substantially among countries. According to La Porta et al. (1998), Scandinavian-civil-law countries show the strongest accounting system quality, followed by countries from common-law tradition and German-civil-law countries. The weakest quality of accounting is found in those countries from the French-civil-law family.

This article focuses on explaining trade credit by using an agency model on a large sample of companies and also testing for the influence of the level of creditor protection and the quality of accounting standards on trade credit policies. According to the model, trade credit policies are defined by a trade-off between two agency costs, adverse selection and moral hazard. Our sample comprises firms from 13 developed and developing countries with distinct levels of financial system development, creditor protection and 
accounting standards. The size and the heterogeneity of our sample allow us to check for the validity of the agency model in the trade credit explanation around the world.

This paper presents three main contributions. First, the sample includes firms from developed and developing countries, from different legal systems, and consequently presenting diverse levels of quality in their creditor protection and accounting systems. As a consequence, this sample allows us to analyse the influence of both factors on the moral hazard phenomenon. Second, we improve the proxy variable for the moral hazard phenomenon in comparison to previous studies by using the "provision for bad debts" data available in Worldscope. Third, we estimate the models using the panel data methodology (GMM system) which, unlike cross-sectional analysis, allows us to control for individual heterogeneity and consequently eliminate the risk of obtaining biased results.

Our results indicate that there is a positive relationship between adverse selection and trade credit extended. In other words, in the presence of information asymmetry, sellers will offer trade credit to provide buyers with time to check the real quality of the products before paying for them. We also find a negative relationship between moral hazard and trade credit extended. This result indicates that, in the presence of information asymmetry, suppliers will reduce the trade credit offer when the risk of buyers' not carrying out the payment when it is due increases. Furthermore, our results also provide empirical evidence of a mitigation effect of the level of creditor protection and accounting standards on the moral hazard phenomenon. Therefore, the negative relationship between moral hazard and trade credit extended will be mitigated in firms from countries of high level of creditor protection or high quality in their accounting standards.

The remainder of this paper is organized as follows. In Section 2, we review the trade credit differences across countries. The agency problem in a trade credit relationship, the influence of the level of creditor protection and the quality of the accounting system in the offer of trade credit and hypotheses are discussed in Section 3. Section 4 presents the data and the empirical strategy, while the results are shown in Section 5. Finally, conclusions are presented in Section 6. 


\section{III.2. Trade credit differences across countries}

In the last three decades many studies have been carried out to investigate trade credit. Although its use can differ significantly depending on where firms are located, strangely, researchers have normally ignored these cross-country differences. Except for some studies (see, for instance, Wei and Zee, 1997; Demirgüç-Kunt and Maksimovic, 2001; Fisman and Love, 2003; Delannay and Weill, 2004; Pike et al., 2005 and; Horen, 2005), most of the literature has only sought the reasons for the differences in trade credit policies between firms by using a firm's specific and internal characteristics, such as differences in firm access to funds (see Brick and Fung, 1984 for tax reasons; or Schwartz, 1974, for financial reasons), in transaction costs (Ferris, 1981; Emery, 1987) or in product quality (Smith, 1987; Emery and Nayar, 1998).

Some of these theories can explain trade credit in a few specific situations, but are not able to explain why there are significant differences in trade credit policies among firms located in different countries. According to the harmonized account data base, $\mathrm{BACH},{ }^{6}$ for the year 2000 (see Bardes, 2002 and Marotta, 2005), Italy is the country that has the highest level of accounts payable and receivable, followed by France and Spain, while Germany has the lowest. Wei and Zee (1997), using the Disclosure Worldscope database, make an international comparison of the use of trade credit among Germany, Japan, the United Kingdom and the United States and again find that Germany shows the lowest levels.

An interesting research study that has found some empirical evidence of crosscountry variations in trade credit used by firms is the one by Demirgüç-Kunt and Maksimovic (2001). In this paper the authors investigate data from 39 countries and also find Italy as the largest trade credit user. However, what does variation really mean and why does it exist? Their main assumption is that trade credit depends on countries' financial systems and legal infrastructure.

Horen (2005), using data from 42 developing countries based on the World Bank Investment Climate Unit (ICU), confirms that the development of the financial system influences the trade credit offered by firms. Specifically, the author suggests and finds

\footnotetext{
${ }^{6} \mathrm{BACH}$-harmonized companies accounts database. It provides data for 11 European Countries, Japan and United States.
} 
some empirical evidence supporting the idea that trade credit is used as a competitiveness tool, mainly by firms in developing countries.

A large body of researchers have already found evidence supporting the idea that the legal system influences economic development, since it is an important determinant of financial institutions (see La Porta et al., 1997, 1998; Levine, 2002; Fisman and Love, 2003, Djankov et al., 2007). However, how does the legal system, and consequently, the legal framework, influence the trade credit offered by firms? According to Safavian and Sharma (2007) "...the extent to which the legal framework allows creditors to enforce their rights to collateral matters to the working of credit markets". This reasoning also works for trade credit markets, that is, a legal framework that is able to mitigate the moral hazard in bank credit operations will also mitigate the risk of buyers' not paying for the products bought when payment is due.

Differences in countries' legal systems include features such as creditors' rights, investors' rights, laws enforcement, accounting standards, etc. In this research we concentrate on two aspects of the legal system: (i) the influence of creditors' rights on trade credit, since we understand that its level is an important determinant of the size of credit markets and, consequently, will result in more or less trade credit use by firms and; (ii) the role played by the level of quality of the accounting system on the trade credit extended by firms, since its variation across countries may result in changes in credit risk as a consequence of the mitigation of information asymmetries.

\section{III.3. Theory and hypothesis}

In order to find out the determinants of a firm's trade credit policy and the variation in the amount of trade credit use among firms from different countries, we propose a model supported by two different dimensions.

\section{III.3.1. The first dimension: the agency problem}

The first dimension includes some firm and product characteristics that explain the differences in trade credit policy among firms trading in asymmetric information 
conditions. In these circumstances the trade credit extended by suppliers to clients is a result of two phenomena, adverse selection and moral hazard. The first phenomenon has been proposed and supported by many research studies, such as Smith (1987), Long, Malitz and Ravid (1993), Lee and Stowe (1993), Emery and Nayar (1998), Wei and Zee (1997) ${ }^{7}$ and Pike et al. (2005). Adverse selection arises when clients do not know ex-ante the quality of the goods they are going to buy. In this case, sellers extend trade credit to guarantee their buyers product quality. This point of view suggests that firms selling high tech products whose reputation has not been consolidated will extend trade credit to allow clients to check the real quality of the goods before payment. Nevertheless, when trade credit is extended, the risk of buyers not making the payment when it is due increases, giving rise to the moral hazard phenomenon.

In other words, moral hazard and adverse selection are two phenomena that arise from sellers and buyers trading in conditions of asymmetric information. This trade-off characterizes an agency relationship between a firm and its clients, first proposed by Jensen and Meckling (1976). Therefore, the two following hypotheses are proposed:

Hypothesis 1: The greater the presence of adverse selection in a relationship between sellers and buyers, the greater the trade credit offered.

Hypothesis 2: The greater the presence of moral hazard in a relationship between sellers and buyers, the less trade credit offered.

\section{III.3.2. The second dimension: countries' specificities}

The second dimension refers to two country characteristics that may distinguish financial patterns of firms from different legal environments: differences in creditor protection and the quality of accounting standards. According to the following arguments, high levels of creditor protection may mitigate the moral hazard costs, and high quality accounting systems mitigate information asymmetries and, consequently, moral hazard costs.

\footnotetext{
${ }^{7}$ These authors find mixed evidence supporting the product quality theory. However they conclude that "the theory is valid at least for some countries and industries"
} 


\section{III.3.2.1. Creditor Protection}

Evidence found by La Porta et al. (1997), Galindo and Micco (2007) and Djankov et al. (2007) supports the explanation of the importance of creditor rights in credit used by firms. They find that the size of credit markets in countries presenting high levels of creditor rights is much larger than in countries presenting weaker creditor protection. Specifically, Levine (2002) finds that countries whose legal systems emphasize creditor rights and contract enforcements have better developed banks.

Countries with lower creditor protection present a high credit risk to lenders. The higher this credit risk, the higher the borrowing cost for firms. Nevertheless, this cost will be lower in trade credit than in bank credit, since according to the transaction cost theory, suppliers may have cost advantages against financial intermediaries in acquisition information.

This view is in agreement with Fisman and Love (2003), who pointed out that: “...even though weak creditor protection and imperfect information will affect both formal intermediaries and trade credit providers, trade creditors may mitigate these problems better than formal lenders...". In this case, non-financial firms (suppliers) are cheaper lenders than banks.

As explained previously, the effect of a weak creditor protection is lower in trade credit than in bank credit. However, it is also important in the explanation of trade credit policies, since the providers' difficulty in seizing their goods when buyers file for reorganization and have not paid for them yet will affect the trade credit risk. Therefore, adding a new argument to the proposed trade-off between adverse selection and moral hazard, depending on the level of creditor protection in a country, the cost of the moral hazard can oscillate. Although trade credit is expected to be proportionally higher ${ }^{8}$ in countries of lower creditor protection, it is also expected that the weakness in creditor rights

\footnotetext{
${ }^{8}$ Considering that trade credit and bank credit are substitutes, we expect that in environments where creditor protection is low, the mix of external finance used by firms will be composed of a higher proportion of trade credit and a smaller proportion of bank debt when compared to firms from countries where creditor protection is high. In this case, trade credit is acting as a mechanism to compensate the higher cost of funds from financial institutions.
} 
may enhance the influence of moral hazard in trade credit extended by providers which, as described above, is expected to be negatively related to trade credit. Therefore, creditor protection will act as a moderator in the moral hazard phenomenon.

This explanation has theoretical support in Galindo and Micco (2007), who point out that the low level of creditor protection becomes more relevant in the development of credit markets during bankruptcy. Naturally, we can broaden this reasoning to a trade credit relationship between firms in the case of buyers presenting a high risk of bankruptcy. Thus, the level of creditors' protection will be more important to the development of trade credit markets along the supply chain when buyers' risk of bankruptcy is high.

The inclusion of the level of creditor protection as a moderator of the moral hazard phenomenon and consequently as an indirect determinant of the trade credit extended also finds support in Pindado et al. (2008), who find that insolvency codes play a crucial role in investment decisions. As trade credit extended by suppliers is a category of investment which, on the one hand, is a short term investment in accounts receivable that stimulates demand, and on the other hand, is an investment in a long term client relationship, creditor protection will influence trade credit policies at least indirectly by the mitigation of moral hazard. Therefore, we pose our third hypothesis.

Hypothesis 3: The quality of creditor protection mitigates the moral hazard effects on trade credit policies.

\section{III.3.2.2. Accounting Standards}

Asymmetric information between lenders and borrowers certainly influences the cost of the credit and its amount. The scarcity of information about a borrower's financial situation or the existence of untrustworthy or precise information about them can lead financial intermediaries to reject credit demands or to increase their cost to compensate the risk. Fisman and Love (2003) find a negative relationship between the accounting standards in a country and credit financing, indicating that the weaker the accounting information the higher the risk of lending for financial intermediaries. Of course, the risk of lending increases for suppliers of trade credit as well, but as suggested by Petersen and Rajan 
(1997), suppliers will have some informational advantages over formal lenders, which leads us to suppose that the scarcity of accounting information about borrowers is more significant for banks than for suppliers.

Therefore, as in the case of creditor's rights, the low quality of the accounting system will affect, with different intensity, both financial intermediaries and trade credit suppliers. Thus, the more information available about a borrower's or a buyer's financial situation, the cheaper the credit offered. Therefore, the quality in the accounting system will act as a moderator in information asymmetries and, consequently, in the moral hazard phenomenon. Therefore, our fourth hypothesis is as follows 9 .

Hypothesis 4: The quality of the accounting standards mitigates the moral hazard effects on trade credit policies.

These theoretical hypotheses can be tested by using a model represented by a function to explain trade credit usage by firms from different legal environments as follows: $\mathrm{DSO}=\phi(\varpi, \mu)$, where DSO is the day of sales outstanding, $\varpi$ stands for the agency costs arising from the adverse selection phenomenon, while $\mu$ represents the agency costs caused by the moral hazard phenomenon. And, as posited above, DSO is directly related to $\varpi$ and inversely related to $\mu$. Additionally, the quality of creditor protection $(\Omega)$ and the quality of accounting standards $(\Psi)$ have been included as factors that moderate the moral hazard phenomenon in trade credit.

The graph shown in Figure 2 allows us to observe the theoretical construction described above. Line $\mathrm{AB}$ represents the adverse selection phenomenon and indicates its expected direct relationship with trade credit. Line CD stands for the moral hazard phenomenon in firms from countries of low creditor protection and low quality in accounting standards. Line CE represents the moral hazard phenomenon in the case of firms from countries of high creditor protection and high quality in accounting standards. In both cases, the expected relationship of moral hazard with trade credit is negative. The graph helps us to understand that, according to the agency model, the trade credit extended

\footnotetext{
${ }^{9}$ The percentage of customers from different countries will certainly affect this relationship, since export firms will trade with clients under different levels of accounting standards.
} 
will be a result of a trade-off between both phenomena, as represented by points TC1 and TC2. Moreover, the graph shows the expected influence of the creditor protection level and the quality of accounting standards on the moral hazard. According to the model, in countries of high creditor protection or with a high quality accounting system we expect that the influence of moral hazard in trade credit policies will decrease. Therefore, when creditor protection is high, as in the United Kingdom, Singapore and Malaysia, the moral hazard line presents a smoother decline as compared to countries where creditor protection is low, as in Mexico and France. As a consequence, the optimum trade credit level point will move to the right as the moral hazard becomes less important in the trade credit policy decision.

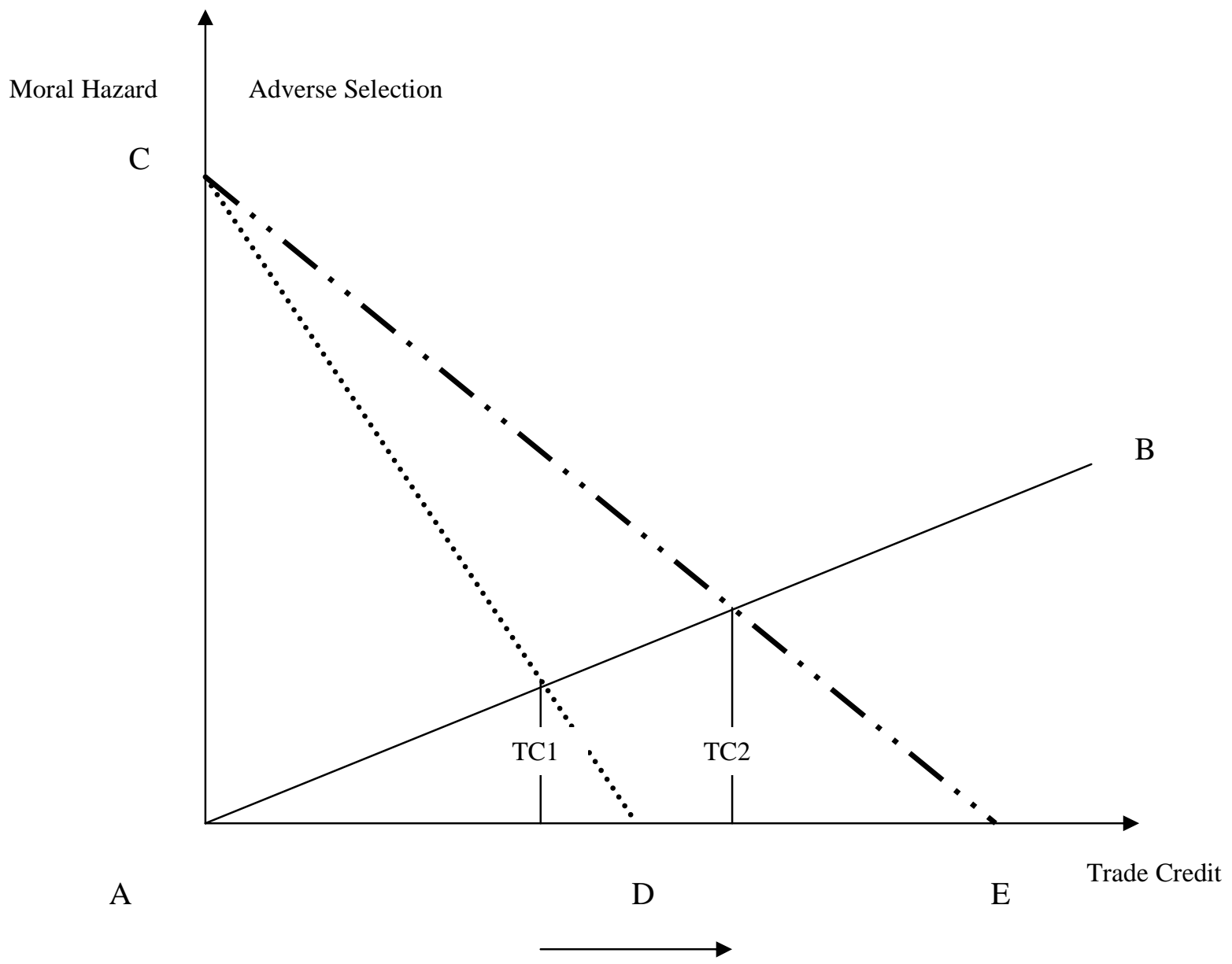

Figure 2: Trade-off between moral hazard and adverse selection and creditor rights/accounting system influence 
Notes:

Adverse Selection

Moral Hazard in countries of high levels of creditor protection or high quality in accounting standards

Moral Hazard in countries of low levels of creditor protection or low quality in accounting standards

In short, trade credit extended will be larger in the case of firms from countries where creditor protection is high, ceteris paribus. The same reasoning is valid for the accounting system, that is, the trade credit extended will be larger in the case of firms from countries where the quality in the accounting system is high, ceteris paribus.

\section{III.4. Data, empirical model and methodology}

\section{III.4.1. Data}

Our original file contained data of companies from 19 different developed and developing countries comprising all legal families described by La Porta et al. (1998). The firm data level was obtained from Worldscope and we used La Porta et al. (1998) to complete all the information about the countries' creditor protection and accounting systems. These 19 countries were selected in order to generate a heterogeneous sample of firms immersed in distinct levels of economic development, creditor rights and accounting systems.

The sample was restricted to manufacturing firms because it is in this category where trade credit takes place in its usual form. We constructed a panel containing at least five consecutive years of information for each company. In this step, five countries were kept out of the sample (Argentina, Denmark, Finland, India, Italy and Pakistan), because they did not fulfil this requirement. We also dropped firm-year data with missing values for our crucial variables. As a result, our sample covers active manufacturing companies (SIC 2000 through 3999) from 1990 to 2003. Therefore, we obtained an unbalanced panel comprising 1,213 companies and 6,508 observations from 13 countries. 


\section{III.4.2. Empirical Model}

Since the aim of this work is to analyze the determinants of trade credit extended, we use two different proxies to measure this variable: the days of sales outstanding (DSO), measured by the natural logarithm of accounting receivable days ${ }^{10}$, available in Woldscope, and the ratio of trade receivables to total assets (TRC). The first is a proxy for how long trade credit is extended and the last is a proxy for the amount of trade credit extended.

Now, we explain each right-side variable to measure for both phenomena, adverse selection and moral hazard. The literature has argued that the adverse selection phenomenon can be proxied by several variables, one of them being reputation. Reputation reduces adverse selection costs and can be proxied by SIZE, as measured by the number of employees in the company. SIZE is expected to be negatively related to DSO.

Another proxy for firm reputation and, consequently, for the adverse selection phenomenon, is a firm's fixed assets, since the larger they are, the smaller the asymmetric information in a trade relationship. Therefore, to measure the suppliers' fixed assets we use FIX, calculated as 1-(Fixed Assets/Total Assets), that is, the inverse of firm's fixed assets. For this variable we expected a positive relationship with DSO.

As the negative consequences of adverse selection can be mitigated by the supplier's profitability, the variable ROA, calculated as earnings before interest and taxes divided by total assets, is used to proxy for firms' profitability. This variable is expected to be negatively correlated to DSO.

As Long, Malitz and Ravid (1993) point out, buyers of high-tech products require a longer time period to verify quality and buyers of perishable products need only a short time to resolve quality uncertainty. These differences in the time requirements for verifying the quality of the products exist because of the variation in the presence of adverse selection costs associated with each type of product. Therefore, we follow Bastos and Pindado (2007) in the construction of the Product Quality Level variable (PQL) ${ }^{11}$. This

\footnotetext{
${ }^{10}$ Accounts receivable days are available in Worldscope calculated as follows: 360 / (Revenues / (Current Year's Receivables + Last Year's Receivables / 2))

${ }^{11}$ We calculate the PQL variable as follows: $\mathrm{PQL}=(30 /(1+$ Natural Logarithm of Total Assets $))$ for technical industries, $\mathrm{PQL}=(0.5 /(1+$ Natural Logarithm of Total Assets $))$ for perishable industries, and $\mathrm{PQL}=(3 /(1+$ Natural Logarithm of Total Assets)) for the remaining firms. The figures 30, 3 and 0.5 have been chosen in order to give more power to the first characteristic related to industry, as suggested in financial literature.
} 
variable takes higher values when the period needed to verify the quality of the product is longer, and vice versa. As a result, the product quality level should be positively related to DSO

The last variable used to proxy adverse selection is the natural logarithm of days to pay accounts payable (DPA), calculated as accounts payable times 360 divided by the cost of goods sold. This variable is entered into the model because high quality firms are prone to increasing the trade credit offered to their clients, and they use this argument to require more trade credit from their suppliers. Therefore, the expected relation between days to pay accounts payable and DSO is positive.

The bad debts provision divided by the net trade receivables (BDP) is used to proxy for the risk of buyers not making the payment when it is due. This measure is used since it represents the main risk for suppliers extending trade credit. The expected relationship between bad debts provision and DSO is negative. Equation 1 represents our model including only those variables described above that are used to proxy for the adverse selection and the moral hazard phenomena, that is, the agency problem.

$\mathrm{DSO}_{\mathrm{it}}=\beta_{0}+\beta_{1} \mathrm{BDP}_{\mathrm{it}}+\beta_{2} \mathrm{PQL}_{\mathrm{it}}+\beta_{3} \mathrm{SIZE}_{\mathrm{it}}+\beta_{4} \mathrm{FIX}_{\mathrm{it}}+\beta_{5} \mathrm{ROA}_{\mathrm{it}}+\beta_{6} \mathrm{DPA}_{\mathrm{it}}+\varepsilon_{\mathrm{it}}$

where $\boldsymbol{\varepsilon}_{\mathbf{i t}}$ is the random disturbance.

To measure the creditor protection in each country of our sample, the index of $\mathrm{La}$ Porta et al. (1998) is used. This index is composed of 4 different aspects of creditor protection in bankruptcy situations: (i)whether restrictions are needed, such as creditor consent, when a debtor files for reorganization; (ii) whether secured creditors are able to seize their collateral after a debtor appeal for reorganization is approved (no automatic stay or asset freeze); (iii) whether a secured creditor has preference in receiving money from the liquidation of a bankrupt firm; (iv) whether during reorganization the head of the firm is an administrator appointed by the court and not the manager. For this index, 0 (zero) represents the weakest creditor protection and 4 (four) corresponds to the strongest.

According to Pindado et al. (2008), these four aspects mentioned above are determinants of the risk borne by bondholders and can increase the likelihood of

However, note that the second characteristic (Natural Logarithm of Total Assets) plays an important role, since it distributes the values within each kind of industry and provides variability to PQL, which is necessary when using the panel data methodology. More details will be provided by the authors upon request. 
underinvestment. As explained in Section 3, trade credit extended is also an investment and its level will also be affected by this measure of creditor protection. Therefore, based on this index we construct a dummy variable by splitting our sample into two groups, one taking the value of zero, containing firms from countries of low levels of creditor protection, that is, with a index value smaller than two and another, taking the value of one, containing firms with high levels of creditor protection, that is, with an index value equal to or greater than two. Hereafter, we refer to this measure as the Creditors' Rights Dummy (CRD).

To proxy for the quality of a country's accounting system we used the accounting standard index (AS), also based on La Porta et al. (1998). This measure is an index checking for the inclusion or the omission of 90 items in annual reports of companies from several countries. We again constructed a dummy variable that takes the value of 1 for firms from countries where the quality of the accounting standards are above average and zero otherwise, that is, countries of high and low quality accounting systems. Hereafter, we refer to this measure as the accounting standard dummy (ASD). Equation 2 represents our model, including, for the moral hazard phenomenon, an interaction dummy variable (INT ${ }_{\mathrm{i}}$ ) that measures the level of a country's creditor protection or the level of a country's quality in accounting standards as described above.

$\mathrm{DSO}_{i \mathrm{t}}=\beta_{0}+\mathrm{BDP}_{\mathrm{it}}\left(\beta_{1}+\lambda \mathrm{INT}_{\mathrm{i}}\right)+\beta_{2} \mathrm{PQL}_{\mathrm{it}}+\beta_{3} \mathrm{SIZE}_{\mathrm{it}}+\beta_{4} \mathrm{FIX}_{\mathrm{it}}+\beta_{5} \mathrm{ROA}_{\mathrm{it}}+\beta_{6} \mathrm{DPA}_{\mathrm{it}}+\varepsilon_{\mathrm{it}}$

where $\mathrm{INT}_{\mathrm{i}}$ represents the country specificity interaction in the moral hazard phenomenon as the creditors' rights index (CR) or the quality of the accounting system (AS) and $\varepsilon_{\mathrm{it}}$ is a random disturbance.

\section{III.4.3. Methodology}

We estimate the proposed model by using panel data methodology for two main reasons. First, unlike cross-sectional analysis, it allows us to control for individual heterogeneity. This heterogeneity could lead to biased results (see, for instance, Moulton, 1986, 1987). Therefore, in our paper we control for heterogeneity by modelling it as an individual effect, $\eta_{\mathrm{i}}$. Consequently, the error term in our models, $\varepsilon_{\mathrm{it}}$, has been split into four components. First, the firm-specific effect, $\eta_{\mathrm{i}}$. Second, $d_{t}$, which is time specific effects and 


\section{A trade credit explanation based on the agency theory, legal factors and credit contagion}

allows us to control for some macroeconomic influences on the trade credit decision. Third, as the estimation of our model uses data from several countries, we included country dummy variables, $c_{\mathrm{i}}$. Finally, $v_{\mathrm{it}}$ is the random disturbance.

The second reason for using panel data methodology is because endogeneity may be a problem in our model. Particularly, firms that receive trade credit from their suppliers use this source of finance to extend credit to their buyers. However, the inverse direction of this relationship may also occur, since high quality suppliers that extend trade credit to their clients use this argument to require more credit from their suppliers. A similar problem also occurs between days of sales outstanding and the provision for bad debts, since the latter is a measure for buyers' moral hazard and when trade credit is extended bad debts are likely to increase. To control for this problem we use all the right-hand-side variables in the model lagged from t-1 to $\mathrm{t}-2$ as instruments for the equations in differences. Therefore, our model in Equation 1 and 2 would be, respectively, as follows:

$\mathrm{DSO}_{\mathrm{it}}=\beta_{0}+\beta_{1} \mathrm{BDP}_{\mathrm{it}}+\beta_{2} \mathrm{PQL}_{\mathrm{it}}+\beta_{3} \mathrm{SIZE}_{\mathrm{it}}+\beta_{4} \mathrm{FIX}_{\mathrm{it}}+\beta_{5} \mathrm{ROA}_{\mathrm{it}}+\beta_{6} \mathrm{DPA}_{\mathrm{it}}+\eta_{\mathrm{i}}+\mathrm{d}_{\mathrm{t}}+\mathrm{c}_{\mathrm{i}}+v_{\mathrm{it}}$

$\mathrm{DSO}_{\mathrm{it}}=\beta_{0}+\mathrm{BDP}_{\mathrm{it}}\left(\beta_{1}+\lambda \mathrm{INT}_{\mathrm{i}}\right)+\beta_{2} \mathrm{PQL}_{\mathrm{it}}+\beta_{3} \mathrm{SIZE}_{\mathrm{it}}+\beta_{4} \mathrm{FIX}_{\mathrm{it}}+\beta_{5} \mathrm{ROA}_{\mathrm{it}}+\beta_{6} \mathrm{DPA}_{\mathrm{it}}+\eta_{\mathrm{i}}+\mathrm{d}_{\mathrm{t}}+c_{\mathrm{i}}+v_{\mathrm{it}}$

where $\eta_{i}$ is an individual effect, $d_{t}$ is the time specific effect, $c_{i}$ are countries' dummy variables and $v_{\text {it }}$ is the random disturbance.

With the aim of checking for the potential misspecification of the models, we also test the joint significance of the reported coefficient by running three Wald tests, where $z_{1}$ is a test of the joint significance of the reported coefficients; $z_{2}$ is a test of the joint significance of the time dummies; and $z_{3}$ is a test of the joint significance of the country dummies. Additionally, we use the Hansen $\mathbf{J}$ statistic of over-identifying restrictions in order to test the absence of correlation between the instruments and the error term. We also use the $\mathrm{m}_{2}$ statistic, developed by Arellano and Bond (1991), in order to test for lack of second-order serial correlation in the first-difference residual. All these statistics are shown joined with the estimation results.

\section{III.5. Results}

In this section we first present the distribution of our sample by industry, by the level of creditor protection and by the level of quality in accounting standards, the descriptive statistics and Pearson's correlation for all variables included in our model. We then 


\section{A trade credit explanation based on the agency theory, legal factors and credit contagion}

estimate the agency model without the inclusion of the countries' specificities as an interaction term. Finally, we test for the importance of the creditor protection level and the accounting standards as a factor that moderates the effect of buyers' risk of default on the trade credit offer by suppliers.

\section{III.5.1. Descriptive Statistics and preliminary results}

The structure of the sample by number of companies and number of observations per level of creditor protection and per level of the quality in accounting standards are provided in Table 6. Note that our sample is balanced between what we consider "high" and "low" levels of creditor protection and "high" and "low" levels of quality in accounting standards.

Table 6: Structure of the sample according to creditor protection and accounting standards Panel A: Number of companies and observations per level of creditor Protection

\begin{tabular}{lllll}
\hline $\mathrm{CR}$ & $\mathrm{N}^{\mathbf{o}}$ of Companies & $\mathrm{N}^{\mathbf{o}}$ of Observations & \% of Total \\
\hline 0 & 193 & 1,435 & 22.05 & \multirow{2}{*}{ LOW LEVEL $(43,73)$} \\
1 & 293 & 1,411 & 21.68 & \\
\hline 2 & 645 & 3,291 & 50.57 & \\
3 & 24 & 130 & 2.00 & HIGH LEVEL $(56,27)$ \\
4 & 58 & 241 & 3.70 & \\
\hline Total & 1,213 & 6,508 & 100.00 & \\
\hline
\end{tabular}

Panel B: Number of companies and observations per level of quality in the accounting standards

\begin{tabular}{lllll}
\hline AS & $\mathrm{N}^{\circ}$ of Companies & $\mathrm{N}^{\circ}$ of Observations & \% of Total \\
\hline 36 & 19 & 122 & 1.88 & \\
54 & 6 & 27 & 0.41 & \\
60 & 2 & 9 & $0.14 \quad$ LOW LEVEL $(54,46)$ \\
62 & 24 & 130 & 2.00 & \\
64 & 32 & 273 & 4.19 & \\
65 & 606 & 2,984 & 45.85 & \\
\hline 69 & 191 & 1,426 & 21.91 & \\
71 & 268 & 1,262 & 19.40 & \\
74 & 4 & 19 & 0.29 & HIGH LEVEL $(45,52)$ \\
76 & 34 & 138 & 2.12 & \\
78 & 24 & 103 & 1.58 & \\
83 & 3 & 15 & 0.23 & \\
\hline Total & 1,213 & 6,508 & 100.00 & \\
\hline
\end{tabular}


Table 7 presents all the countries included in our sample and their respective level of creditor protection and accounting system. Note that the countries are dispersed in their levels of creditor protection and accounting system.

Table 7: Creditors' rights index and accounting standards index for all countries in the sample

\begin{tabular}{|c|c|c|}
\hline Countries & CR & $\mathrm{AS}$ \\
\hline \multicolumn{3}{|c|}{ Civil Law (French-origin) } \\
\hline France & 0 & 69 \\
\hline Spain & 2 & 64 \\
\hline Portugal & 1 & 36 \\
\hline Brazil & 1 & 54 \\
\hline Mexico & 0 & 60 \\
\hline \multicolumn{3}{|c|}{ Civil Law (German-origin) } \\
\hline Germany & 3 & 62 \\
\hline Japan & 2 & 65 \\
\hline \multicolumn{3}{|c|}{ Civil Law (Scandinavian-origin) } \\
\hline Norway & 2 & 74 \\
\hline Sweden & 2 & 83 \\
\hline \multicolumn{3}{|c|}{ Common Law (English-origin) } \\
\hline UK & 4 & 78 \\
\hline US & 1 & 71 \\
\hline Singapore & 4 & 78 \\
\hline Malaysia & 4 & 76 \\
\hline
\end{tabular}

The observations in our sample are industry dispersed, i.e., the sample does not appear to be more concentrated in any industry. Table 8 shows the distribution by industry for our sample.

Table 8: Sample distribution by industry

\begin{tabular}{clcc}
\hline SIC & \multicolumn{1}{c}{ Industry } & Number & $\%$ \\
\hline 20 & Food and Kindred Products & 554 & 8.517 \\
21 & Tobacco Products & 9 & 0.14 \\
22 & Textile Mill Products & 156 & 2.40 \\
& Apparel and Other Finished Products Made from Fabrics and Similar & 169 & 2.60 \\
23 & Materials & & \\
24 & Lumber And Wood Products, Except Furniture & 71 & 1.09 \\
25 & Furniture and Fixtures & 94 & 1.44 \\
26 & Paper and Allied Products & 185 & 2.84 \\
27 & Printing, Publishing, and Allied Industries & 128 & 1.97 \\
28 & Chemicals and Allied Products & 848 & 13.03 \\
29 & Petroleum Refining and Related Industries & 71 & 1.09 \\
30 & Rubber and Miscellaneous Plastic Products & 247 & 3.80 \\
31 & Leather and Leather Products & 45 & 0.69
\end{tabular}


32 Stone, Clay, Glass, and Concrete Products

$237 \quad 3.64$

33 Primary Metal Industries

$412 \quad 6.33$

Manufactured Metal Products, Except Machinery and Transport

$353 \quad 5.42$

34 Equipment

35 Industrial and Commercial Machinery and Computer Equipment

$912 \quad 14.01$

Electronic and Other Electrical Equipment and Components, Except

$930 \quad 14.29$

36 Computer Equipment

37 Transport Equipment

$516 \quad 7.93$

Measuring, Analyzing, and Controlling Instruments; Photographic,

$396 \quad 6.08$

38 Medical and Optical Goods; Watches and Clocks

39 Miscellaneous Manufacturing Industries $\quad 175 \quad 2.69$

Total

$6,508 \quad 100.00$

This table shows the distribution by industry for the 6,508 observations.

Summary statistics for the variables used in our analysis and Pearson's correlations are shown in Table 9. The days of sales outstanding is around 95 days. Note that correlation coefficients are moderate and do not violate the assumption of independence between explanatory variables. Not surprisingly, all dependent variables included in the model present the expected relation with DSO. The positive signs of PQL and FIX and the negative signs of SIZE and ROA suggest that smaller and less profitable firms producing high quality products and presenting a small proportion of fixed assets related to total assets tend to offer more trade credit to their clients. These outcomes support the idea that in asymmetric information environments there is a positive influence of adverse selection on the trade credit offered by sellers. The results for DPA also support the adverse selection phenomenon in the trade credit extended by providers. Regarding the BDP variable, the negative sign of the relationship with DSO was as expected by the proposed model.

Table 9: Descriptive statistics and Pearson's correlations

\begin{tabular}{lrrrrrrrrrr}
\hline & Mean & S. Deviation & Median & \multicolumn{1}{c}{ DSO } & BDP & PQL & SIZE & FIX & ROA & DPA \\
\hline DSO & 4.485 & 0.414 & 4.533 & 1.000 & & & & & & \\
BDP & 0.082 & 1.071 & 0.020 & -0.009 & 1.000 & & & & & \\
PQL & 1.165 & 1.000 & 1.557 & 0.162 & 0.021 & 1.000 & & & & \\
SIZE & 7.906 & 1.709 & 7.648 & -0.182 & -0.021 & -0.108 & 1.000 & & & \\
FIX & 0.707 & 0.138 & 0.716 & 0.169 & 0.013 & 0.338 & -0.141 & 1.000 & & \\
ROA & 0.048 & 0.105 & 0.043 & -0.204 & 0.024 & -0.083 & 0.106 & 0.048 & 1.000 & \\
DPA & 4.183 & 0.531 & 4.252 & 0.452 & -0.059 & 0.060 & 0.046 & 0.038 & -0.162 & 1.000 \\
\hline
\end{tabular}

This table provides the mean, the standard deviation, the median, and the Pearson's correlations for the 6,508 observations. DSO denotes the natural logarithm of days of sales outstanding, BDP stands for the second power of bad debt provision divided by total assets, PQL denotes the product quality level, SIZE is the natural logarithm of the number of employees of the firm, FIX is the fixed assets proportion of total assets, ROA 


\section{A trade credit explanation based on the agency theory, legal factors and credit contagion}

stands for earnings before interest and taxes divided by total assets, and DPA denotes the natural logarithm of days to pay accounts payable.

We also test for the difference in days of sales outstanding between firms from countries of high and low levels of creditor protection. The same test was run for firms from countries of high and low quality accounting systems. Results in Table 10 show that firms from countries where creditor protection is high extend more trade credit than those located in countries where creditor protection is low. These outcomes are evidence in favour of the idea that lower levels of creditor rights may diminish not only the amount of bank credit available but also the trade credit offered by suppliers. These results are consistent with those found by Fisman and Love (2003), Galindo and Mico (2005) and Safavian and Sharma (2007).

Table 10: Test of independent samples

\begin{tabular}{llll}
\hline Variables & High CR & Low CR $^{\mathrm{b}}$ & $\begin{array}{c}\text { T-Statistic of } \\
\text { Difference }\end{array}$ \\
\hline $\begin{array}{l}\text { Days of Sales } \\
\text { Outstanding }\end{array}$ & 104.0658 & 85.52565 & $-20.4248^{*}$ \\
\hline Variables & High AS & Low AS $^{\mathrm{d}}$ & $\begin{array}{c}\text { T-Statistic of } \\
\text { Difference }\end{array}$ \\
\hline $\begin{array}{l}\text { Days of Sales } \\
\text { Outstanding }\end{array}$ & 86.14715 & 104.1583 & $19.8885^{*}$ \\
* Significant at the 0.01 level. \\
$\begin{array}{l}\text { a High CR is defined as CR equal or greater than 2. } \\
\text { b Low CR is defined as CR index less than 2. } \\
\text { c High AS is defined as AS index greater than average (66.85). } \\
\text { d Low AS is defined as AS index under than average (66.85). }\end{array}$
\end{tabular}

Preliminary results for differences in DSO between firms from countries of different accounting systems show that firms from countries presenting high quality in their accounting standards extend less trade credit than those from countries where the accounting standards present low levels of quality. This result may occur because financial reports are likely to be more important for banks, since suppliers have informational advantages in acquisition information about buyers' creditworthiness. Although we understand that high quality in the accounting standards is very important for the credit decision in the bank sector, we also consider that a high quality accounting system also favours a trade credit decision and should, at least, mitigate the moral hazard costs present in a trade relationship. 


\section{III.5.2. Results for the agency model}

The results of the GMM estimation of our agency model are provided in Column I of Table 11. Coefficients for all variables that are proxies for adverse selection present the expected sign and, except for DPA, are significant at the $1 \%$ level. The variable ROA is negatively related to DSO, indicating that profitable firms tend to offer a shorter period of credit. The variable SIZE is negatively related to DSO, giving support to the argument that large and well-established firms tend to offer less credit to their clients. PQL is positively related to DSO, supporting that firms producing high quality products tend to offer more credit to their clients to allow them to assess the quality of goods before payment. FIX is positively related to DSO, supporting that firms with a large proportion of fixed assets tend to extend less credit to clients since tangible assets mitigate information asymmetries. All these results yield strong evidence in favour of a positive relationship between adverse selection and trade credit extended and consequently support Hypothesis 1.

Table 11: Estimations results

\begin{tabular}{lccc}
\hline Explanatory Variables & $(\mathrm{I})$ & $(\mathrm{II})$ & $(\mathrm{III})$ \\
\hline $\mathrm{DSO}_{\mathrm{it}-1}$ & $0.8070182^{*}$ & $0.8065625^{*}$ & $0.7994892^{*}$ \\
& $(0.0027917)$ & $(0.0017489)$ & $(0.0014077)$ \\
$\mathrm{BDP}_{\mathrm{it}}$ & $-0.0021076^{*}$ & $-0.0082181^{*}$ & $-0.0854915^{*}$ \\
& $(0.0004063)$ & $(0.0003119)$ & $(0.0012036)$ \\
$\mathrm{CRD}_{\mathrm{it}}{ }^{*} \mathrm{BDP}_{\mathrm{it}}$ & - & $0.006841^{*}$ & - \\
& - & $(0.0005106)$ & - \\
$\mathrm{ASD} \mathrm{BDP}^{\mathrm{n}}$ & - & - & $0.0837446^{*}$ \\
$\mathrm{ROA}_{\mathrm{it}}$ & - & - & $(0.001247)$ \\
& $-0.2158091^{*}$ & $-0.2158615^{*}$ & $-0.2212084^{*}$ \\
$\mathrm{SIZE}_{\mathrm{it}}$ & $(0.0090072)$ & $(0.0044247)$ & $(0.0054363)$ \\
& $-0.0069287^{*}$ & $-0.0110325^{*}$ & $-0.0086201^{*}$ \\
$\mathrm{DPA}_{\mathrm{it}}$ & $(0.0009708)$ & $(0.0004525)$ & $(0.0005186)$ \\
& 0.0002108 & 0.0011698 & 0.0010408 \\
$\mathrm{PQL}_{\mathrm{it}}$ & $(0.0018253)$ & $(0.0008244)$ & $(0.0011731)$ \\
& $0.0098456^{*}$ & $0.0076157^{*}$ & $0.010218^{*}$ \\
FIX $_{\mathrm{it}}$ & $(0.0009052)$ & $(0.0003244)$ & $(0.0003301)$ \\
& $0.178817^{*}$ & $0.1777168^{*}$ & $0.1575226^{*}$ \\
$\mathrm{Const}$ & $(0.0097991)$ & $(0.0043614)$ & $(0.0066489)$ \\
& $1.038491^{*}$ & $1.066129^{*}$ & $1.091373^{*}$ \\
$\mathrm{~T}$ & $(0.0211224)$ & $(0.0168437)$ & $(0.0161428)$ \\
$\mathrm{z}_{1}$ & - & -3.5538856 & -4.8933783 \\
$\mathrm{z}_{2}$ & $37214.63(7)$ & $1.2 \mathrm{e}+05(8)$ & $1.3 \mathrm{e}+05(8)$ \\
& $496.07(11)$ & $1212.60(11)$ & $1354.63(11)$
\end{tabular}


$\mathrm{Z}_{3}$

$\mathrm{M}_{1}$

$\mathrm{M}_{2}$

Hansen
$337.10(13)$

$-1.93$

$416.72(274)$
$538.81(13)$

$-8.32$

$-1.95$

$446.22(307)$
$702.61(13)$

$-8.30$

$-1.93$

The table presents parameter estimates from panel GMM regressions of Days of Sales Outstanding on several different specifications. The dependent variable is the natural logarithm of days of sales outstanding, and the details about the independent variables are in Table 9. The rest of the information needed to read this table is: i) Heteroscedasticity consistent asymptotic standard error in parentheses; ii) *, ** and *** indicate significance at the $1 \%, 5 \%$ and $10 \%$ level, respectively; iii) $t$ is the t-statistic for the linear restriction test under the null hypothesis of no significance; iv) $\mathrm{z}_{1}, \mathrm{z}_{2}, \mathrm{Z}_{3}$ are the Wald tests of the joint significance of the reported coefficients, of the time dummies and of the country dummies, respectively, asymptotically distributed as $\chi^{2}$ under the null of no significance, degrees of freedom in parentheses; $v$ ) $\mathrm{m}_{\mathrm{i}}$ is a serial correlation test of order $\mathrm{i}$ using residual in first differences, asymptotically distributed as $\mathrm{N}(0,1)$ under the null of no serial correlation; vi) Hansen is a test of the over-identifying restrictions, asymptotically distributed as $\chi^{2}$ under the null of no correlation between the instruments and the error term, degrees of freedom in parentheses.

The results of the estimation also provide empirical evidence in favour of a negative relationship between the moral hazard phenomenon and the trade credit extended. The coefficient for the BDP variable is negative and significant at the $1 \%$ level. This indicates that suppliers tend to tighten terms of credit when they notice an increase in the possibility of buyers' default. Therefore, we can confirm Hypothesis 2.

The results described here support Hypotheses 1 and 2 in that: (i) suppliers tend to offer more credit when they are not well known by the clients, such as those which are smaller, less profitable and have a small proportion of fixed assets; and (ii) suppliers will reduce the trade credit offered when the risk of their clients increases. In this case, suppliers will try to mitigate the moral hazard cost by shortening the trade credit period of its clients.

Finally, all the results together highlight the validity of the agency model in explaining trade credit policies adopted by firms around the world. This agency model is based on the proposition of Jensen and Meckling (1976) in which two phenomena arise from the relationship between a firm and its clients, in asymmetric information conditions: adverse selection and moral hazard. The former is an agency cost that emerges when clients do not know ex-ante the quality of the goods that are being acquired and therefore require a period to verify product quality before payment. The latter is an agency cost that arises when sellers do not know ex-ante the creditworthiness of their clients and therefore reduce the trade credit extended. 


\section{III.5.3. The moderating role of creditors' rights}

To find out whether trade credit offered by firms is in any way influenced by a country's level of creditor protection, we again run the model but including an interaction effect on the BDP variable (see Equation 4). With this aim, as explained in Section 4, we construct a dummy variable that takes the value of one if the creditors' rights index is equal to or greater than 2 and zero otherwise. We therefore extend the agency model by interacting the creditors' rights index obtained in La Porta et al. (1998) and here transformed into a dummy, with the provision for bad debts (BDP). Column II of Table 11 gives the results.

All the variables used to proxy for the adverse selection and the moral hazard phenomena show the same results as in the previous model. Specifically, the coefficients for ROA, SIZE, PQL and FIX still significant and present the same sign of the basic model, again giving support to Hypothesis 1. The result for the variable BDP, which in the basic model presented an expected negative relation with DSO, again supports Hypothesis 2, since its coefficient is still significant in this extended model. Overall, this evidence provides a robustness check for our results.

The results for the influence of the level of creditor protection on moral hazard point to two different facts. First, when the creditor protection of a country is high, the dummy variable takes the value of 1 and, consequently, the coefficient is $\beta_{2}+\gamma_{1}$. We have performed a linear restriction test whose null hypothesis is $\mathrm{H}_{0}: \beta_{1}+\gamma_{1}=0$ in order to know if the coefficient $\beta_{1}+\gamma_{1}=-0.0013771$ is significantly different from zero. As the $t$-value is -3.55 , we can reject the null hypothesis that the coefficient is equal to zero. This result supports our explanation that in countries where credit protection is high the moral hazard effect is mitigated, and, in this case, the trade-off existing in the trade credit policy decision will tilt in favour of the adverse selection that will predominate since clients' risk importance will diminish for trade credit policy makers. Second, when a country's creditor protection is low, the dummy variable takes the value of zero and the coefficient is $\beta_{1}=-0.0082181$, indicating that in these countries the clients' risk will represent a very heavy weight in the suppliers' decision of how long trade credit should be extended. 


\section{A trade credit explanation based on the agency theory, legal factors and credit contagion}

Therefore, we can confirm that creditor rights act to mitigate the negative effect of the moral hazard phenomenon on credit extended, thus giving support to our Hypothesis 3. As we theorized in Section 3, high levels of creditor's rights alleviate the moral hazard effects on trade credit.

Therefore, the level of a country's creditor protection acts in favor of the development of the credit markets. This does not occur only in the case of bank credit, as suggested by previous studies, but also in the case of trade credit. Furthermore, the improvement of creditors' rights will probably bring benefits to trade relations between suppliers and buyers because of the reduction in the moral hazard costs. All these results strongly support our approach in explaining the role of the level of creditor protection as a moderator of the relationship between trade credit extended and moral hazard costs.

\section{III.5.4. The moderating role of the quality of the accounting system}

Finally, to check for the validity of Hypothesis 4, we perform a third estimation to confirm whether the quality of a country's accounting system also moderates the moral hazard in trade credit extended. With this aim, we again run the model in Equation 4, but this time using a dummy for the AS index as an interaction on BDP. As explained in Section 4, this dummy takes the value of one if the accounting system index is greater than average and zero otherwise.

As shown in column III of Table 11, the results for the proxies for adverse selection and for moral hazard again support our previous results, that is, all the variables included in the model without interactions maintain the same relationship with the dependent variable. Turning our attention to the level of the quality of the accounting system, the result supports our explanation that in high quality accounting system countries the moral hazard effect is mitigated. Again we perform a linear restriction test whose null hypothesis is $\mathrm{H}_{0}: \beta_{1}+\gamma_{1}=0$ in order to know if the coefficient $\beta_{1}+\gamma_{1}=-0.0017469$ is significantly different from zero. As the t-value is -4.89 , we can reject the null hypothesis and conclude that the coefficient is significantly different from zero.

As a consequence, high quality accounting systems mitigate the effect of the moral hazard in a trade credit decision. In this case, suppliers from these countries will give less 
importance to buyers' risk in comparison to those firms from countries where the quality of the accounting system is low. Therefore, results from this last estimation provide empirical evidence supporting Hypothesis 4 in that the moral hazard effects on trade credit are stronger in suppliers from countries with a low quality accounting system.

\section{III.5.5. Robustness Test}

Columns I to III of Table 12 give the results from the same models using as a dependent variable TRC, measured by the ratio of trade receivables to total assets. As explained before, this measure is a good proxy for trade credit extended because it complements DSO. While DSO is used to assess how long trade credit has been extended, TRC quantifies the amount of trade credit extended by suppliers.

Table 12: Estimations results - robustness checks

\begin{tabular}{|c|c|c|c|}
\hline Explanatory Variables & (I) & (II) & $\overline{(\mathrm{III})}$ \\
\hline \multirow[t]{2}{*}{$\mathrm{TRC}_{\mathrm{it}-1}$} & $0.613973 *$ & $0.6074278 *$ & $0.6126192 *$ \\
\hline & $(0.0050757)$ & $(0.0035106)$ & $(0.0025159)$ \\
\hline \multirow[t]{2}{*}{$\mathrm{BDP}_{\text {it }}$} & $-0.0029648^{*}$ & $-0.0203535 *$ & $-0.0508026^{*}$ \\
\hline & $(0.0004333)$ & $(0.0005036)$ & $(0.0006125)$ \\
\hline \multirow[t]{2}{*}{$\mathrm{CRD}_{\mathrm{it}} * \mathrm{BDP}_{\mathrm{it}}$} & - & $0.0184557 *$ & - \\
\hline & - & $(0.0005032)$ & - \\
\hline \multirow[t]{2}{*}{$\mathrm{ASD} * \mathrm{BDP}$} & - & - & $0.0480631 *$ \\
\hline & - & - & $(0.0006673)$ \\
\hline \multirow[t]{2}{*}{$\mathrm{ROA}_{\mathrm{it}}$} & $0.0349389 *$ & $0.0347032 *$ & $0.0361553^{*}$ \\
\hline & $(0.0036168)$ & $(0.0023283)$ & $(0.0020736)$ \\
\hline \multirow[t]{2}{*}{$\mathrm{SIZE}_{\mathrm{it}}$} & $-0.0031483^{*}$ & $-0.0045607 *$ & $-0.0036663^{*}$ \\
\hline & $(0.0003261)$ & $(0.0001612)$ & $(0.0001544)$ \\
\hline \multirow[t]{2}{*}{$\mathrm{DPA}_{\text {it }}$} & $0.0286654 *$ & $0.0287636^{*}$ & $0.0284515^{*}$ \\
\hline & $(0.000931)$ & $(0.0006222)$ & $(0.0002813)$ \\
\hline \multirow[t]{2}{*}{$\mathrm{PQL}_{\text {it }}$} & $0.0034416^{*}$ & $0.0025737 *$ & $0.0033031 *$ \\
\hline & $(0.0003608)$ & $(0.0002128)$ & $(0.0001095)$ \\
\hline \multirow[t]{2}{*}{ FIX $_{\text {it }}$} & $0.0482065^{*}$ & $0.0568653 *$ & $0.0479648 *$ \\
\hline & $(0.0027451)$ & $(0.0009841)$ & $(0.0016498)$ \\
\hline \multirow[t]{2}{*}{ Const. } & $0.0608963 *$ & $0.0698005^{*}$ & $0.0673014 *$ \\
\hline & $(0.00514)$ & $(0.0041943)$ & $(0.0040858)$ \\
\hline $\mathrm{T}$ & - & -36.293338 & -7.9482289 \\
\hline $\mathrm{z}_{1}$ & $7558.29(7)$ & $81708.06(8)$ & $71313.17(8)$ \\
\hline $\mathrm{z}_{2}$ & $1481.25(11)$ & $3559.00(11)$ & $7239.10(11)$ \\
\hline $\mathrm{z}_{3}$ & $115.40(13)$ & $152.93(13)$ & $176.81(13)$ \\
\hline $\mathrm{m}_{1}$ & -10.18 & -10.16 & -10.16 \\
\hline
\end{tabular}


The table presents parameter estimates from panel GMM regressions of trade receivables on several different specifications. The dependent variable is the trade receivables divided by total assets (TRC), and the details about the independent variables are in Table 9. The rest of the information needed to read this table is: i) Heteroscedasticity consistent asymptotic standard error in parentheses; ii) *** and $* * *$ indicate significance at the $1 \%, 5 \%$ and $10 \%$ level, respectively; iii) $t$ is the t-statistic for the linear restriction test under the null hypothesis of no significance; iv) $\mathrm{z}_{1}, \mathrm{z}_{2}, \mathrm{z}_{3}$ are the Wald tests of the joint significance of the reported coefficients, of the time dummies and of the country dummies, respectively, asymptotically distributed as $\chi^{2}$ under the null of no significance, degrees of freedom in parentheses; v) $\mathrm{m}_{\mathrm{i}}$ is a serial correlation test of order $\mathrm{i}$ using residual in first differences, asymptotically distributed as $\mathrm{N}(0,1)$ under the null of no serial correlation; vi) Hansen is a test of the over-identifying restrictions, asymptotically distributed as $\chi^{2}$ under the null of no correlation between the instruments and the error term, degrees of freedom in parentheses.

As shown in Column I, with the exception of ROA, all proxies for the adverse selection and moral hazard phenomena keep the same sign. The main difference here is the coefficient of DPA, which is now significant. Our findings support the hypothesis that the greater the adverse selection problem the more trade credit offered. Variable SIZE is negatively related to TRC and variables PQL and FIX are positively related to it supporting that large and low quality producers, with a high proportion of fixed assets, tend to offer a shorter period of credit since they have already built a reputation and, therefore, buyers will not need long periods to check product quality. The positive and significant sign of the coefficient of DPA indicates that as high quality firms extend more trade credit to clients, they use this argument to require more trade credit from their suppliers.

Regarding the coefficient of the BDP variable, it is again negative and significant. This result confirms that the greater the moral hazard cost the smaller the trade credit offered by suppliers. As a consequence, trade credit extended by suppliers will be a result of a trade-off between both phenomena, adverse selection and moral hazard. Therefore, the outcomes reported here allow us to confirm Hypotheses 1 and 2.

Columns II and III show the results for both extended models, one that CRD interacts with BDP and the other that ASD interacts with BDP. As can be seen, the results again provide evidence in favour of Hypotheses 3 and 4. In both cases, the coefficients for the interaction term (INT) are as expected. These results provide an excellent robustness check for our hypotheses.

In a nutshell, trade credit consists of an agency relationship between suppliers and their clients in which, in asymmetric information conditions, buyers will need time to check the quality of the goods before paying for them (the adverse selection phenomenon), and 
suppliers will diminish the time of the credit extended as they do not know the creditworthiness of the client(the moral hazard phenomenon). However, in countries with high levels of creditor protection or high quality of accounting standards, the moral hazard is mitigated since the credit risk is diminished.

\section{III.6. Conclusions}

In the present paper we test an agency model to explain trade credit policy. The model considers that two phenomena arise from the relationship between providers and buyers: adverse selection and moral hazard. In this context, and in asymmetric information conditions, trade credit policy is a result of an agency relationship between providers and buyers, in which trade credit is extended to allow clients to check the real quality of the goods they are buying before the payment is made. In the meantime, sellers do not know, ex-ante, the creditworthiness of the buyer and thus they will reduce the trade credit offered as they notice an increase in the risk of buyers' default. This model is then extended to test for the moderator effect of different levels of creditor protection and accounting standards in the relationship between moral hazard and trade credit.

When trading with sellers who have not yet built a good reputation in the market, that is, in the presence of adverse selection costs, buyers will demand time to check quality before payment. In addition, providers will reduce the terms of credit in order to mitigate the moral hazard costs that vary depending on the level of creditor protection and the quality of the accounting standards in a country. This means that high levels of creditor protection increase the suppliers' probability of receiving the goods sold and consequently mitigate the moral hazard effects on trade credit. In addition, high quality accounting systems mitigate information asymmetries between buyers and sellers and consequently diminish the moral hazard costs.

This study contributes to understanding the importance of legal institutions in the finance of economic activities. In this vein, an important conclusion drawn from this research is that countries with creditor unfriendly commercial laws and low quality of accounting standards will provide a risky environment for credit, not only to formal lenders but also to suppliers when extending trade credit. Therefore, if the high quality of creditor 
protection and the accounting system acts in favour of the development of the trade credit, changes in theses issues should be taken by governments, which should consider all the benefits involved for the development of commerce and consequently of the economy. 


\section{CHAPTER IV - TRADE CREDIT DURING AN ECONOMIC CRISIS: A PANEL DATA ANALYSIS}

\section{IV.1. Introduction}

During the Asian crisis at the end of the last decade, the Financial Times stated that economists are aware that a financial crisis in one country spreads to others and that this contagion is usually stronger in times of market instability than in periods of calm. In addition, trade and investment links are obvious channels of contagion since a crisis in one country deteriorates exports and capital flows to that country's trading partners (Chote and Daniel, 1998). If during market turbulence a contagion effect occurs between linked economies, then the effect will consequently occur between firms, because they consist of trade partners with investment links. This contagion has specific consequences in the trade credit supply chain, because suppliers often invest in trade relationships by extending trade credit that can tighten as bank credit becomes constrained.

The study of trade credit during economic crisis periods is an important topic, particularly when the global economy is going through a credit shock. Regarding the recent 2008 global crisis, Kazmin, Lamont, and Leahy (2008) argue that the reluctance of commercial banks to lend caused a liquidity shock at every level of the system. This liquidity shock caused a shift in trade credit use levels because on the one hand, trade credit may act as a substitute source of funds and thus increase, but on the other hand, trade credit may complement bank credit and decrease.

Although significant differences exist in trade credit use for firms around the world, trade credit is one of the most important sources of short-term finance. According to Demirgüç-Kunt and Maksimovic (2001), in countries such as France, Germany, and Italy, accounts payable or accounts receivable can reach $25 \%$ of firms' total assets. In general, theories that explain trade credit embrace commercial reasons, transactions costs motivations, and financial incentives (e.g., Brick and Fung, 1984; Ferris, 1981; Smith, 1987; Petersen and Rajan, 1997; Wei and Zee, 1997; Deloof and Jegers, 1999; Marotta, 
2005; Bastos and Pindado, 2007; Rodriguez-Rodriguez, 2008; Deloof and Overfelt, 2010). Recently, some studies appear to explain trade credit uses by firms from different locations and with different levels of economic development or legal systems (e.g., Demirgüç-Kunt and Maksimovic, 2001; Fisman and Love, 2003; Horen, 2005; Bastos and Pindado, 2009).

Only a few empirical studies about trade credit during economic crises exist, such as Fukuda, Kasuya and Akashi (2006) and Tsuruta (2007) for Japan's crisis and Love, Preve and Sarria-Allende (2007) for the Asian crisis. However, the impact of an economic crisis on trade credit finance is of enormous relevance because a crisis causes trade credit contagion as a consequence of financial contagion between financial intermediaries.

The study of trade credit supply and demand during periods of economic crisis is strongly related to the financial view that firms with wide access to credit from financial intermediaries finance, through trade credit, those firms with limited credit (Meltzer, 1960; Schwartz, 1974). However, Blasio (2005) explains that trade credit determinants contain both time-invariant and time-variant components. In this vein, this study argues that trade credit explanations must take into account both dimensions of these explanations. Therefore, the study examines trade credit demand by considering commercial, operational, and financial motives during the Brazilian crisis of 1999, the Turkish collapse of 2001, and the Argentine crisis of 2001-2002. The sharp devaluation of its currency marked the Brazilian crisis of 1999, along with an increase in interest rates and a decrease in the Brazilian reserves of dollars. The Argentine crisis of 2001/2002 was long anticipated following the recession that began in 1997 (the Asian crisis followed by the Russian default). According to Zurawicki and Braidot (2005), the crisis' strongest symptoms were negative growth rates and increases in unemployment. The financial literature at the time considered the devaluation of the Brazilian Real against the Argentine Peso and the persistent deterioration of fiscal revenues as triggers of the crisis, which caused doubt to emerge about the government's ability to honor its debt. Regarding Turkey, the devaluation of $40 \%$ in its currency, the Lira, which made repayments of debt in foreign currency difficult for banks and businesses, characterized the Turkish collapse of 2001. Peterson, Ekici, and Hunt (2010) argue that the Turkish economic crisis of 2001 negatively impacted all sectors of the country and caused a worsening in income disparities more than any previous economic crisis in that country. In light of the above, this paper presents three 
main contributions: First, the sample includes firms from three countries that the literature does not widely study. Second, the paper explains the effects of an economic crisis on trade credit demand. The third contribution is the choice of method. When firms' trade credit policies are studied, two serious problems arise. On the one hand, firms have their own specificities that lead to a particular behavior and can influence the trade credit extended and used. Consequently, the firm's unobservable heterogeneity must be taken into account in the models because heterogeneity can affect trade credit practices. A potential problem of endogeneity exists in the relation between trade credit use and its determinants. Therefore, this paper uses the panel data methodology to eliminate the unobservable heterogeneity and to estimate the models by using the Generalized Method of Moments (GMM) to control for endogeneity.

This study empirically observes that trade credit used is positively related to trade credit extended, the market power of the customer firm, and the level of investment opportunities presented by firms. The study also observes that trade credit used is negatively related to firms' access to credit from financial intermediaries. Also, the study finds that during years of economic shocks that a contagion effect enhances the positive relation between trade credit demand and the level of accounts receivable. The contagion effect also increases the positive relation between trade credit demand and the probability of insolvency.

The remainder of this paper is structured as follows. Section 2 reviews the literature on trade credit and credit contagion and Section 3 reports theories and hypotheses. The method and empirical strategy are presented in Section 4. Section 5 discusses the main results and Section 6 presents conclusions.

\section{IV.2. Literature review of trade credit and credit contagion}

Trade credit determinants can be classified into time-variant and time-invariant categories. Although theories based on price discrimination, product quality, and transaction costs are time invariant, theories based on a financial argument are time variant. Blasio (2005) argues that trade credit extended by suppliers has both a financial and a transaction component. According to this author, the financial component represents an 
alternative source to bank credit that can vary over time depending on credit market conditions. The transaction component is useful for making the exchange of goods easier and consists of a time-invariant aspect of trade credit.

The financial theory of trade credit (Meltzer, 1960, Schwartz, 1974; Emery, 1984) posits that firms with easy and large access to credit markets finance those with limited access. The tax argument (Brick and Fung, 1984), included in this body of research, suggests that if buyers and sellers are in different tax brackets, they have different borrowing costs, because interest is tax deductible. As a consequence, suppliers in high tax brackets (with lower borrowing costs) are likely to extend trade credit to buyers in lower tax brackets (with higher borrowing costs).

This strand of the literature contains some time-invariant arguments such as those presented by Petersen and Rajan (1997), in which suppliers ( i ) have some cost advantages over banks in acquiring information about the buyer's creditworthiness; ( ii ) can also threaten to cut off future supplies to buyers; and ( iii ) have more ability to salvage values from existing assets that depends on the nature of the goods. However, the access to credit markets varies over time and for this reason trade credit policies also are different in monetary contractions than in financial crises.

Many research studies follow Meltzer's (1960) and Schwartz's (1974) financial explanation for trade credit. Some of them, such as Nilsen (2002) and Baum, Caglayan, and Ozkan (2003) focus on the relevance of monetary contractions or macroeconomic uncertainty in the trade credit offered by firms. The former find empirical evidence that during periods of monetary contractions small firms have less access to bank loans and thus use more trade credit. The latter find support for the argument that during macroeconomic uncertainty firms turn to their supplier as a source of finance, particularly those larger, high growth, non-durable-goods producers.

Other works in the same strand of the literature provide empirical evidence linking trade credit demand and credit rationing; see, for instance, Danielson and Scott (2004). According to these authors, credit rationing increases trade credit demand for more opaque firms. Wilner (2000) argues that in long term relationships, a dependent creditor grants more concessions when a customer is in financial distress. Delannay and Weill (2004), in agreement with Marotta (1997) and Nilsen (2002), posit that trade credit acts as a substitute 
for bank credit in credit-rationed companies such as those from transition economies. In another recent paper, Uesugi and Yamashiro (2008) investigate the opposite direction of influence, that is, how decreasing the extension of trade credit affects the extension of lending from financial institutions. They find that trade credit and bank credit are complementary.

Rodriguez-Rodriguez (2008) study trade credit granted by small and medium size firms from the Canary Islands based on the argument that credit-constrained firms have suppliers as important substitutes for banks and find that firms with greater access to institutional finance act by channeling credit to financially constrained clients.

As described above, most papers in this body of literature suggest that creditconstrained firms demand more trade credit than others. However, the offer of trade credit during financial crisis periods can follow a different pattern because of a variety of factors, such as certain buyer specificities that can increase the borrowing risk and cause credit contagion.

According to Kaufman (1994), contagion consists of the spillover of consequences of shocks from one or more firms to others. Giesecke and Weber (2006) define credit contagion as the propagation of economic distress from one firm to another. During the last decade and at the beginning of this decade, a number of countries experienced financial crises and scholars investigated their relation to financial contagion.

During banking distress, panicked depositors withdraw their bank deposits. According to Friedman and Schwartz (1963), these withdrawals are a primary mechanism through which banking distress affects the real economy. Indeed, this fact also occurs in the trade credit supply chain, because panic suppliers diminish their investment in customer relationships by withdrawing trade credit or by tightening terms of credit.

In a recent paper, Love, Preve, and Sarria-Allende (2007) find that the provision of trade credit increases right after a crisis, but contracts in the following months and years. They posit that this effect occurs because at first trade credit acts as a substitute for bank borrowing, thus offsetting the unavailability of credit from financial intermediaries. Later, however, the decline in bank credit causes a credit scarcity effect for suppliers that tightens the terms of credit. 
According to Tsuruta (2007), if suppliers act as financial intermediaries as well, they suffer from credit contagion just as the banks do. He proposes a model for the contagion of trade credit in the Japanese crisis of 1997 and suggests that in that period, suppliers were likely to diminish the amount of credit extended to all firms, be they high or low risk, and to those presenting high values of trade receivables. The argument for this relation is that in the case of a serious credit contagion the possibility of default is higher for both high and low risk firms, and particularly for those with high trade receivables.

Jorion and Zhang (2009) posit that contagion effects are stronger for an industrial counterparty than for a financial institution in the case of a borrower default, because the usual trade credit exposure accounts for a large proportion of supplier assets and usually, one or a few buyers represent a large proportion of a supplier's trade credit. Therefore, when a buyer files for bankruptcy it is likely to create financial distress for that supplier. According to these authors, the bankruptcy of a trade partner leads a firm to a double negative consequence, the increase in bad debts and the loss of an important customer relationship.

Jorion and Zhang (2009) explain channels of credit correlation in non-financial firms well by dividing the different effects into three categories: (i) intra-industry contagion; (ii) contagion effects across industries; and (iii) counterparty effects. In the intra-industry contagion, when Firm A defaults, two opposite effects are expected. On the one hand, there are the negative effects on firms in the same industry. On the other hand, competitors of the firm that filed for bankruptcy can expand their market share. The contagion effect across industries occurs when the default of Firm A, who is a key client of Firm B from Industry $\mathrm{B}$, acts as a negative sign of sales prospect for firms in Industry B. The counterparty effect consists of losses in Firm B, caused by trade credit extended to Firm A who defaulted. As a consequence, a cascading counterparty effect can occur to Firm $\mathrm{C}$ who gave trade credit to Firm B. This effect can occur successively, causing financial distress to many firms in a supply chain. Note that this paper fits in the third category described, counterparty effects. 


\section{IV.3. Theory and hypotheses}

As shown earlier, time-invariant and time-variant factors explain trade credit used. The former embrace certain arguments such as those related to commercial motives or transaction costs. The latter concern financial motives; however, the financial motivation in trade credit uses has both a time-variant and a time-invariant component. In this section, the paper explains the hypotheses and theory related to splitting them into two subsections.

IV.3.1. The first dimension: commercial, financial, and operational motives; time-invariant components

Petersen and Rajan (1997) explain that suppliers are better able to investigate the creditworthiness of buyers. They have a better knowledge of the industry situation, prospects, and threats as they are part of that production chain. In addition, suppliers have a strong interest in the survival of their clients and, according to Delannay and Weill (2004), suppliers make large investments in the long-term customer relationship, hence they have an implicit stake in the buyer. As a result, suppliers have a more accurate perception of their clients' business and investment opportunities. $\mathbf{H}_{1}$ : Firms presenting a high versus low level of investment opportunities receive more trade credit from their suppliers.

Although the financial argument of trade credit posits that large firms are likely to use less trade credit because they have more access to external funds (Rodriguez-Rodriguez, 2008) and because small firms are more informationally opaque (Zambaldi, Aranha, Lopes and Politi, 2010), the commercial view argues that large firms have more bargaining power with their providers. This bargaining power allows large firms to require better payment conditions because they can threaten to change to another supplier. In this case, any trade credit extended is not the result of a seller decision, but a consequence of the buyer's bargaining power and resultant pressure (Horen, 2005). Indeed, size does not measure creditworthiness and banks can not grant credit to large firms simply because of their size. The positive relation between size and trade credit received is also in accordance with the product quality theory in which small firms that have not yet built their reputation grant more credit to their clients. The above explanation can also be based on the resource 
dependence concept. Dependency arises from the trade relationship with partners. Gopinath (1995) argues that when the dependency is asymmetric, the strongest party (in this case large customers) exercises control (requires credit) over the more dependent party (the supplier). Indeed, Mottner and Smith (2009) affirm that when a supplier becomes financially dependent on a powerful buyer, the former gives financial concessions to the latter. H2: Large versus small firms receive more trade credit from their suppliers as a result of their strong bargaining power.

As firms sell and buy on credit, those firms that delay in collecting from their customers then demand long term trade credits from their suppliers. Indeed, Fabbri and Klapper (2008) affirm that firms are likely to match the maturities of the contract terms for their payables and receivables. In addition, high quality firms are prone to increase the trade credit offered to their clients, and they use this argument to require more trade credit from their suppliers. $\mathbf{H}_{3}$ : Firms are likely to match the maturities of the contract terms of their trade receivables and their accounts payable.

According to the operation argument, trade credit is a way to reduce transaction costs that arise when demand is irregular. Variations in demand cause customer queues, large inventories, and, consequently, enhance transaction costs (Ferris, 1981; Emery, 1984). Rodriguez-Rodriguez (2008) argues that the use of trade credit enhances commercial exchange flows as a consequence of a decrease in costs inherent to cash payment and in the uncertainty of the transactions, namely liquidation costs and storage costs. She argues that the more active firms use more trade credit as a source of finance. Uesugi and Yamashiro (2008) relate the benefits of trade credit uses in the reduction of transactions costs and argue that the larger the transaction volume more frequently firms use trade credit. $\mathbf{H}_{\mathbf{4}}$ : The more active a firm is the more trade credit the firm uses.

As explained in Section 2, trade credit and credit from financial intermediaries can represent substitute sources of funds and, therefore, credit-constrained firms apply for more trade credit than those with greater access to the financial market. Firms that face restrictions to bank credit access usually have low levels of fixed assets to grant as collateral and a high insolvency risk. H5: Firms with reduced access to banks use more trade credit than firms with large access. 
IV.3.2. The second dimension: crisis periods and the time-variant component

A firm can be credit constrained because of its own financial characteristics, such as the lack of collateral, low profitability, and high liquidation risk, and these specificities are time-invariant aspects. They can also be credit constrained because of a temporary situation that affects credit markets, which is a time-variant effect. On one hand, in periods of economic crisis, panicked suppliers can diminish their investment in customer relationships by withdrawing trade credit or by tightening the terms of credit. But on the other hand, the effort made by suppliers to collect earlier might not be enough because of the contagion effect that occurs in economic crisis periods.

This contagion can occur because firms with high levels of accounts receivable do not succeed in collecting them in time and have to postpone payments to their suppliers, which leads to a credit contagion chain, because suppliers can act in exactly the same way with their respective suppliers. Thus, in crisis periods, not only suppliers' credit policy determines trade payables, but also a probable credit contagion effect that arises from the buyers having high levels of trade receivables.

The same relation occurs between trade payables and the probability of insolvency. As those firms with liquidity problems tend to suffer credit restrictions when appealing to banks, they finance themselves by using trade credit. However, their insolvency situation, added to the economic circumstances, can reduce the probability of payments being made at the proper time. As a consequence, not only suppliers' trade policy but also buyers' ability to pay determines the relation between trade payables and the risk of insolvency. H6: During crisis periods, the credit contagion effect enhances the positive relation between trade payables and trade receivables. H7: During crisis periods, the credit contagion effect enhances the positive relation between trade payables and the probability of insolvency. 


\section{IV.4. Data, empirical model, and methodology}

\section{IV.4.1. Data}

To test all the hypotheses proposed in Section 3, the paper uses firm data obtained from Worldscope. The sample is composed of 147 firms and 611 observations from Argentina, Brazil, and Turkey covering the five year period from 1999 to 2003, for which data for at least three years are available. This study chooses these three countries because they recently went through an economic crisis. Although in the last decade and at the beginning of this one, several economic crises occurred around the world, the data limitations did not allow the study to expand this research to other countries. The distribution of the sample by country is in Table 13. The sample excludes all public services and financial firms (SIC 4011 through 4991 and 6021 through 9995).

Table 13: Data distribution by country

\begin{tabular}{lcc}
\hline Country & Firms & Observations \\
\hline Argentina & 18 & 74 \\
Brazil & 70 & 291 \\
Turkey & 59 & 246 \\
Total & 147 & 611 \\
\hline
\end{tabular}

\section{IV.4.2. Empirical Model}

Because the goal of this paper is to analyze trade credit uses between firms during a five year period, which includes some of the latest economic crisis periods, the paper proposes to test the following empirical models:

$$
\begin{aligned}
& \text { DPA }_{i t}=\beta_{0}+\beta_{1} \text { DSO }_{i t}+\beta_{2} \text { PI }_{i t}+\beta_{3} \text { FIX }_{i t}+\beta_{4} \text { SIZE }_{i t}+\beta_{5} \text { ASTU }_{\mathrm{it}}+\beta_{6} \mathrm{IO}_{\mathrm{it}}+\varepsilon_{\mathrm{i}} \\
& \text { DPA }_{\mathrm{it}}=\beta_{0}+\left(\beta_{1}+\lambda \mathrm{CRISIS}_{\mathrm{t}}\right) \mathrm{DSO}_{\mathrm{it}}+\beta_{2} \mathrm{PI}_{\mathrm{it}}+\beta_{3} \mathrm{FIX}_{\mathrm{it}}+\beta_{4} \mathrm{SIZE}_{\mathrm{it}}+\beta_{5} \mathrm{ASTU}_{\mathrm{it}}+\beta_{6} \mathrm{IO}_{\mathrm{it}}+\varepsilon_{\mathrm{i}} \\
& \text { DPA }_{\mathrm{it}}=\beta_{0}+\left(\beta_{1}+\lambda \mathrm{CRISIS}_{\mathrm{t}}\right) \mathrm{PI}_{\mathrm{it}}+\beta_{2} \mathrm{DSO}_{\mathrm{it}}+\beta_{3} \mathrm{FIX}_{\mathrm{it}}+\beta_{4} \mathrm{SIZE}_{\mathrm{it}}+\beta_{5} \mathrm{ASTU}_{\mathrm{it}}+\beta_{6} \mathrm{IO}_{\mathrm{it}}+\varepsilon_{\mathrm{i}}
\end{aligned}
$$

As a proxy for our dependent variable of trade credit demand, the paper uses the days to pay accounts payable (DPA), measured by the natural logarithm of $360 /$ (cost of goods sold/accounts payable). 
To measure the trade credit extended to customers, the paper uses the natural logarithm of 360 / (Net Sales or Revenues / (Current Year's Receivables-Net + Last Year's Receivables-Net / 2)), hereafter, days of sales outstanding (DSO). For this variable, it can be anticipated a positive relation with the dependent variable.

In general, firms able to obtain funds from financial markets rely proportionally less on financing from suppliers. Usually, firms with a high level of collateral are prone to obtain credit from banks. In addition, high-credit rated firms, such as those with a low probability of insolvency, are likely to obtain funds from financial intermediaries. Indeed, Paul and Wilson (2007) find that firms with difficulties in obtaining finance from banks demand more trade credit. The variables used to represent the credit quality of a firm and the availability of collateral have the following definitions.

The probability of insolvency, PI, represents the credit quality of a firm that gives it access to formal credit based on the method developed by Pindado, Rodrigues, and de la Torre (2008). Specifically, the model that represents the probability of financial insolvency is as follows:

$\operatorname{Prob}(\mathrm{Y}>0)=\beta_{0}+\beta_{1} \mathrm{EBIT}_{\mathrm{it}} / \mathrm{TA}_{\mathrm{it}}+\beta_{2} \mathrm{TD}_{\mathrm{it}} / \mathrm{MVA}_{\mathrm{it}}+\beta_{3} \mathrm{CP}_{\mathrm{it}} / \mathrm{TA}_{\mathrm{it}}+\mathrm{d}_{\mathrm{t}}+\eta_{\mathrm{i}}+v_{\mathrm{it}}$

where the dependent variable is a binary variable that takes the value of one for financially distressed companies, and zero otherwise. To classify a firm as financially distressed, the firm's leverage has to be above the third quartile or the firm presents an earning before interest taxes, depreciation, and amortization under the first quartile of the sample. The explanatory variables included in the model are Earning Before Interest and Taxes (EBIT) scaled by total assets (TA), Total Debt (TD) scaled by the market value of assets (MVA), and Cumulative Profitability (CP) scaled by total assets. The model uses a logit model to estimate in cross-section. The values obtained vary from zero to one; thus the model is a suitable index to represent the probability of insolvency that creditors assign before granting credit to a customer firm. As seen in Section 3, is expected a positive coefficient for this explanatory variable.

In general, firms with low levels of fixed assets are credit constrained because these types of assets can be used as collateral in bank loans. If these firms usually obtain credit from financial intermediaries, then they show low uses of trade credit, because both types 
of credit are substitutable. To test for the negative relation between collateral and DPA, the model uses the firms' total fixed assets scaled by total assets, FIX.

To assess firm size, the model uses the natural logarithm of total assets (SIZE). This variable often represents firm size in financial literature and particularly in trade credit literature. The arguments exposed in Section 3 indicate that a positive relation between the dependent variable and the SIZE variable exists, because these firms are likely to have more bargaining power over suppliers and require better payment conditions.

Transaction cost theory (operation argument) posits that trade credit is a way to reduce operational costs caused by variations in demand. Therefore, more active firms use more trade credit from suppliers to finance their working capital. The variable ASTU, measured by income divided by total assets, represents firms' activity. According to these arguments, is expected a positive relation between the dependent variable and the DPA variable.

The next explanatory variable is IO that is a proxy for Tobins' q, also used by Han, Suk, and Suk (1999) and Thomsen and Pedersen (2000). The paper measures IO by using the market-to-book value of equity. Information regarding investment opportunities gives to banks and suppliers an idea of a firm's future and provides, particularly to suppliers, an incentive to maintain long-term relationships with these buyers. In addition, the information about a firm's investment opportunities reduces uncertainty about its future. According to Petersen and Rajan (1997), suppliers are able to obtain and use different types of information than banks do and they apparently use this information advantage to sell on credit to firms of low creditworthiness but which present high business potential. Consequently, is expected a positive coefficient for the IO variable.

Also, the paper creates a dummy variable named CRISIS that takes one if a country, $\mathrm{i}$, goes through an economic crisis in year $\mathrm{t}$, and zero otherwise. For the countries comprising the sample, the paper considers the following crisis years: 1999 for Brazil, 2001 for Turkey, and 2001 and 2002 for Argentina. The $\varepsilon_{i t}$ represents the random disturbance. Table 14 summarizes each variable and sign. 
A trade credit explanation based on the agency theory, legal factors and credit contagion

Table 14: Definitions of variables

\begin{tabular}{clc}
\hline Proxy for: & Variable Name & Expected Sign Coefficient \\
\hline Trade credit granted & DSO - days of sales outstanding & + \\
Credit worthiness & PI - Probability of Insolvency & + \\
Bargain Power & SIZE - Total Assets & + \\
Collateral & FIX - Fixed Assets & - \\
Investment Opportunities & IO - Market-to-book-ratio of equity & + \\
Activity & ASTU - Asset Turnover & + \\
\hline
\end{tabular}

\section{IV.4.3. Method}

The study estimates the proposed model by using a panel data method for two main reasons, or problems, that arise when studying trade credit: the unobservable heterogeneity and the endogeneity. First, unlike cross-sectional analysis, the panel data methodology allows us to control for individual heterogeneity. This problem is very important in the analysis of firms' trade credit use, since it may depend on some of the firms' own characteristics. This heterogeneity can lead to biased results. Therefore, the paper controls for heterogeneity by modeling it as an individual effect, $\eta_{i}$, which is then eliminated by taking first differences of the variable. Consequently, the error term in the models, $\varepsilon_{\mathrm{it}}$, is split into four components. First, the firm-specific effect, $\eta_{i}$. Second, $d_{t}$, which is the time specific effects and controls for some of the macroeconomic influences on the trade credit demand decision. Third, as the estimation of the model uses data from three countries, the model includes country dummy variables, $c_{i}$. Finally, $v_{i t}$ is the random disturbance.

The second reason for using the panel data methodology is the endogeneity problem that is likely to arise given that the dependent variable may also explains some of the rightside variables. Particularly, suppliers tend to match their terms of trade credit offered (DSO) and received (DPA). However, for these variables there may be a double direction in the relation, because, on the one hand, firms may define their trade credit policies and, after that, try to negotiate terms of credit with suppliers. On the other hand, firms buy goods from suppliers and then, depending on the suppliers' terms of credit, they decide their own policies. Consequently, endogeneity can be a problem that the models need to control for. To do so, the paper uses all the right-hand-side variables in the model lagged from t- 1 to $t-4$ as instruments for the equations in differences, and one instrument for the equations in 
levels, as Blundell and Bond (1998) suggest, when deriving the system estimator used in the paper. Therefore, the models in Equations 1, 2, and 3 are, respectively, as follows:

$$
\begin{aligned}
& \mathrm{DPA}_{\mathrm{it}}=\beta_{0}+\beta_{1} \mathrm{DSO}_{\mathrm{it}}+\beta_{2} \mathrm{PI}_{\mathrm{it}}+\beta_{3} \mathrm{FIX}_{\mathrm{it}}+\beta_{4} \mathrm{SIZE}_{\mathrm{it}}+\beta_{5} \mathrm{ASTU}_{\mathrm{it}}+\beta_{6} \mathrm{IO}_{\mathrm{it}}+\eta_{\mathrm{i}}+\mathrm{c}_{\mathrm{i}}+v_{\mathrm{it}} \\
& \text { DPA }_{i t}=\beta_{0}+\left(\beta_{1}+\lambda \text { CRISIS }_{\mathrm{t}}\right) \mathrm{DSO}_{\mathrm{it}}+\beta_{2} \mathrm{PI}_{\mathrm{it}}+\beta_{3} \mathrm{FIX}_{\mathrm{it}}+\beta_{4} \mathrm{SIZE}_{\mathrm{it}}+\beta_{5} \mathrm{ASTU}_{\mathrm{it}}+\beta_{6} \mathrm{IO}_{\mathrm{it}}+\eta_{\mathrm{i}}+\mathrm{c}_{\mathrm{i}}+v_{\mathrm{it}} \\
& \text { DPA }_{\mathrm{it}}=\beta_{0}+\left(\beta_{1}+\lambda \text { CRISIS }_{\mathrm{t}}\right) \mathrm{PI}_{\mathrm{it}}+\beta_{2} \mathrm{DSO}_{\mathrm{it}}+\beta_{3} \mathrm{FIX}_{\mathrm{it}}+\beta_{4} \mathrm{SIZE}_{\mathrm{it}}+\beta_{5} \mathrm{ASTU}_{\mathrm{it}}+\beta_{6} \mathrm{IO}_{\mathrm{it}}+\eta_{\mathrm{i}}+\mathrm{c}_{\mathrm{i}}+v_{\mathrm{it}}
\end{aligned}
$$

In Equation 6, according to the theory discussed in Section 3, when CRISIS equals zero (no crisis), $\beta_{1}$ is greater than zero because trade credit is expected to be directly related to trade debt for countries in periods without a crisis and, consequently, without trade credit contagion. However, when CRISIS equals one, that is, in the year $\mathrm{t}$ a credit contraction occurs in country i, $\beta_{1}+\lambda$ is larger than $\beta_{1}$ when CRISIS equals zero. The increase in the coefficient occurs because suppliers' efforts to diminish the amount of credit granted to firms holding high values of trade receivables are offset by an increase in customer trade credit demand as a consequence of the unavailability of bank credit. Likewise, in Equation 7 , when CRISIS equals zero (no crisis), $\beta_{1}$ is positive because financial institutions neglect firms with a high liquidation risk and therefore these firms appeal for more supplier finance. Nevertheless, when CRISIS equals one, that is, in year t a credit contraction occurs in country i, $\beta_{1}+\lambda$ is positively stronger than $\beta_{1}$ when CRISIS equals zero. This result occurs because during crisis periods, risky customers are likely to postpone payments of goods bought on credit because other sources of credit are scarce. This customer reaction gives rise to a credit contagion effect in the supply chain. The expected results from both interactions have the same cause and consequences: the trade credit contagion. It seems clear that in order to avoid the increase in bad debts, in periods of financial crisis, suppliers tighten the terms of credit, particularly for risky firms such as those with a high amount of receivables or a high liquidation risk. However, precisely because of the crisis, and consequently, credit scarceness, buyers delay trade payments with the aim of surviving during the economic crisis.

Also, for all estimations described the paper checks for the potential misspecification of the models. First, the paper tests for the absence of correlation between the instruments and the error term by using the Hansen J statistic of over-identifying restrictions. Second, the paper tests for the lack of second-order serial correlation in the first-difference residual by using the $m_{2}$ statistic, developed by Arellano and Bond (1991). The paper also uses three 


\section{A trade credit explanation based on the agency theory, legal factors and credit contagion}

Wald tests, $z_{1}, z_{2}$, and $z_{3}$, to verify the joint significance of the reported coefficient, the time dummies, and the country dummies, respectively.

\section{IV.5. Results}

At first, this section presents some descriptive statistics. After that, the section shows the results for the model described in Equation 5. This analysis allows the paper to check for the relation between trade credit use and all the variables included in the model without considering any crisis or credit contagion. Afterward, the model estimates the interaction effect of DSO and CRISIS and PI and CRISIS, as described in Equations 6 and 7, respectively.

\section{IV.5.1. Descriptive Statistics}

Table 15 shows the descriptive statistics and Pearson's correlation for all variables included in the model. Paying attention to the volume of trade credit and trade debt of the firms is especially important to the analysis. The average days of sales outstanding is 81 , while the average of days to pay accounts payable is 59, that is, 22 days shorter. Note that correlation coefficients are moderate.

Table 15: Descriptive statistics and Pearson's correlations

\begin{tabular}{lcccccccccr}
\hline Variable & Mean & S. Deviation & Median & DPA & DSO & PI & SIZE & FIX & IO & TATO \\
\hline DPA & 59.28 & 39.41 & 49.57 & 1.00 & & & & & & \\
\hline DSO & 81.43 & 46.48 & 73.00 & $0.22^{*}$ & 1.00 & & & & & \\
PI & 0.42 & 0.25 & 0.38 & $0.20^{*}$ & $0.11^{*}$ & 1.00 & & & & \\
SIZE & 12.46 & 1.46 & 12.40 & 0.04 & -0.06 & $0.06^{* * *}$ & 1.00 & & & \\
FIX & 0.39 & 0.19 & 0.39 & 0.00 & $-0.22^{*}$ & $0.38^{*}$ & $0.20^{*}$ & 1.00 & & \\
IO & 1.41 & 2.17 & 1.05 & 0.03 & -0.06 & $-0.30 *$ & 0.02 & $-0.21^{*}$ & 1.00 & \\
ASTU & 0.99 & 0.48 & 0.96 & $-0.16^{*}$ & $-0.30^{*}$ & $-0.31^{*}$ & $-0.37^{*}$ & $-0.40^{*}$ & $0.07 * * *$ & 1.00 \\
\hline
\end{tabular}

IV.5.2. Testing time-invariant components of trade credit

Table 16 provides the results of the GMM estimation of the models shown in Equation 5, 6 and 7. It also provides the heteroscedasticity consistent asymptotic standard 
error in parentheses, the $t$-statistic for the linear restriction test under the null hypothesis of non-significance and the Hansen test of the over-identifying restrictions, asymptotically distributed as $\chi^{2}$ under the null of no correlation between the instruments and the error term. The levels of $1 \%, 5 \%$ and $10 \%$ of significance are indicated by $* * *$ and $* * *$, respectively. The Wald tests of the joint significance of the reported coefficients, of the time dummies and of the country dummies are indicated by $z_{1}, z_{2}$ and $z_{3}$, respectively, and degrees of freedom are in parentheses; $m_{\mathrm{i}}$ is a serial correlation test of order i using residual in first differences, asymptotically distributed as $\mathrm{N}(0,1)$ under the null of no serial correlation. Regarding Column 1, that shows results for the model of Equation 5, coefficients for all variables included in the model, except for ASTU, are significant and show the expected relation with the dependent variable. Coefficients for DSO, PI, SIZE, and IO are all positive and for FIX, negative.

In accordance with Hypothesis 1, the positive relation between DPA and IO suggests that suppliers extend trade credit to those firms with a high level of investment opportunities. This result provides empirical evidence that supports the advantage that suppliers have over financial intermediaries in acquiring information about buyers' future prospects. This relation has theoretical support in the fact that as suppliers and buyers are likely to maintain a stronger relationship with each other than they maintain with banks, they more easily perceive the information about investment opportunities as compared to banks. Therefore, the information results in more trade credit granted, since suppliers have an interest in the future cash flow of buyers.

The coefficient of SIZE is positive. This result supports the Horen (2005) argument in that suppliers selling to large clients tend to allow payment delays in order to avoid their moving to another supplier. In other words, firms with a large market share or ones that represent a high proportion of suppliers' sales have strong bargaining power to demand better payment conditions. Therefore, this finding confirms Hypothesis 2.

The empirical evidence supports a positive relation between trade credit granted and trade credit used, because the coefficient of DSO is positive and significant. This result supports Hypothesis 3, in that firms that delay collection from their customers, demand long term trade credit from their suppliers. 
According to the financial view of trade credit, liquidity firms with access to financial intermediaries finance the credit constrained firms. This proposition is in agreement with the substitution argument in that credit-constrained firms substitute bank credit as a source of finance for trade credit in periods of credit crisis. Credit-constrained firms usually have a high risk of insolvency and a low level of fixed assets to grant to banks as collateral. Thus, the positive relation found between PI and DPA and the negative relation found between FIX and DPA support these points of view and, consequently, Hypothesis 5.

In short, trade credit received by firms depends on how credit constrained they are when dealing with financial institutions, their investment opportunities, their bargaining power to pressure suppliers for better buying conditions, and the extent of the credit they grant to their customers.

Table 16: Estimations results

\begin{tabular}{|c|c|c|c|}
\hline Explanatory Variables & (I) & (II) & (III) \\
\hline \multirow[t]{2}{*}{$\mathrm{DSO}_{\text {it }}$} & $0.14 * * *$ & $0.10 *$ & $0.11 *$ \\
\hline & $(0.05)$ & $(0.03)$ & $(0.04)$ \\
\hline \multirow[t]{2}{*}{$\mathrm{DSO}_{\mathrm{it}} * \mathrm{CRISIS}_{\mathrm{it}}$} & - & $0.01 * *$ & - \\
\hline & - & $(0.00)$ & - \\
\hline \multirow[t]{2}{*}{$\mathrm{PI}_{\mathrm{it}}$} & $0.39 *$ & $0.39 *$ & $0.48 *$ \\
\hline & $(0.05)$ & $(0.05)$ & $(0.05)$ \\
\hline \multirow[t]{2}{*}{$\mathrm{PI}_{\mathrm{it}}{ }^{*} \mathrm{CRISIS}_{\mathrm{it}}$} & - & - & $0.27 *$ \\
\hline & - & - & $(0.04)$ \\
\hline \multirow[t]{2}{*}{$\mathrm{SIZE}_{\mathrm{it}}$} & $0.06^{*}$ & $0.06^{*}$ & $0.05 *$ \\
\hline & $(0.02)$ & $(0.02)$ & $(0.01)$ \\
\hline \multirow[t]{2}{*}{ FIX $_{\text {it }}$} & $-1.00 *$ & $-1.06^{*}$ & $-1.10 *$ \\
\hline & $(0.15)$ & $(0.11)$ & $(0.13)$ \\
\hline \multirow[t]{2}{*}{$\mathrm{IO}_{\text {it }}$} & $0.02 *$ & $0.02 *$ & $0.03 *$ \\
\hline & $(0.01)$ & $(0.00)$ & $(0.00)$ \\
\hline \multirow{2}{*}{$\operatorname{ASTU}_{\text {it }}$} & 0.10 & $0.12 * *$ & 0.05 \\
\hline & $(0.06)$ & $(0.05)$ & $(0.05)$ \\
\hline \multirow[t]{2}{*}{ Constant } & $3.01 *$ & $3.18 *$ & $3.15 *$ \\
\hline & $(0.36)$ & $(0.30)$ & $(0.24)$ \\
\hline$T$ & - & 3.24 & 11.15 \\
\hline$z_{1}$ & $27.71(6)$ & $43.01(7)$ & $61.60(7)$ \\
\hline$z_{2}$ & $7.47(3)$ & $16.17(3)$ & $11.14(3)$ \\
\hline$z_{3}$ & $12.69(3)$ & $15.62(3)$ & $11.27(3)$ \\
\hline$m_{1}$ & -2.78 & -2.80 & -2.89 \\
\hline$m_{2}$ & -1.33 & -1.25 & -1.16 \\
\hline Hansen & $114.04(98)$ & $125.38(109)$ & $125.04(109)$ \\
\hline
\end{tabular}




\section{IV.5. 3. Testing for crisis effects on trade credit}

To find out whether economic crisis periods in any way influence trade credit policies, the model adds an interaction effect on the DSO variable. The goal of this analysis is to check for empirical evidence of credit contagion occurring in periods of crisis. With this purpose in mind, as explained in Section 4, the paper constructs a dummy variable that takes the value of one if in year t, country i goes through an economic crisis, and zero otherwise. Therefore, the model interacts the CRISIS dummy with the days of sales outstanding (DSO). Column II of Table 16 reports the results for the model represented by Equation 6.

The results for the influence of economic crisis on trade credit received point to two different facts. First, in crisis periods, the dummy variable takes the value of one and, consequently, the coefficient is $\beta_{1}+\gamma_{1}$. The paper performs a linear restriction test whose null hypothesis is $H_{0}: \beta_{1}+\gamma_{1}=0$ in order to know if the coefficient $\beta_{1}+\gamma_{1}=0.11$ is significantly different from zero. As the t-value is 3.24, the paper rejects the null hypothesis that the coefficient is equal to zero. This result supports the argument that in moments of credit constraints caused by an economic crisis, customers that hold high levels of trade receivables postpone payments to suppliers to avoid an increase in their liquidity risk, because they might not receive payment for their sales made on credit, and they have no other source of finance to use. Second, when there is no economic crisis, the dummy variable takes the value of zero and the coefficient is $\beta_{1}=0.10$, indicating the usual positive relation between trade credit granted and received without the payment delay caused by contagion. Of note, in periods without crisis, the positive relation between trade credit used and trade credit granted is weaker than during crisis periods.

Therefore, the results confirm that economic crises affect trade credit uses as firms holding high levels of receivables postpone trade credit payment to suppliers, thus giving rise to a trade credit contagion and supporting Hypothesis 6.

To move forward in the examination of trade credit contagion effects the paper performs a third estimation to check whether periods of economic crisis influence the relation between a firm's insolvency risk and trade credit use. With this aim, the paper runs the model in Equation 7, which includes a dummy for the crisis period interacted with PI. 
As explained in Section 4, this dummy takes the value of one if country i went through an economic crisis in year $\mathrm{t}$, and zero otherwise.

Column 3 of Table 16 shows the results for DSO, SIZE, FIX, and IO. The results support earlier findings in that firms with a low proportion of fixed assets use more trade credit, because financial intermediaries neglect them and those firms that are large or present high investment opportunities get more credit from suppliers, because they have strong market power to delay payables for longer periods and because the suppliers have advantages in acquiring information about the buyers' potential for future growth.

Turning attention to the impact of crisis periods on trade credit policies by analyzing the interaction of the dummy CRISIS on PI, the result supports the explanation that economic shocks enhance the positive relation between trade credit used by firms and their probability of insolvency. Suppliers that substitute for banks by granting credit to firms with a high liquidation risk can tighten credit to them during crisis periods. However, customers facing liquidity problems and without any alternative source of credit delay payments to suppliers. Again, the paper performs a linear restriction test whose null hypothesis is $H_{0}: \beta_{1}+\gamma_{1}=0$ in order to know if the coefficient $\beta_{1}+\gamma_{1}=0.75$ is significantly different from zero. As the $\mathrm{t}$-value is 11.15 , the paper can reject the null hypothesis and concludes that the coefficient is significantly different from zero.

As a consequence, in periods of credit constraints, suppliers' efforts to tighten the terms of credit to risky firms is not successful because the firms with a high probability of insolvency are likely to postpone supplier payments because there are no other sources of credit available to them. Therefore, the results from this estimation provide empirical evidence supporting Hypothesis 7, in that during economic crises a contagion effect also occurs in the relationship between suppliers and their customers.

\section{IV.5.4. Robustness checks}

To test the robustness of the results found, the paper again runs all the estimations but uses as a dependent variable the accounts payable scaled by firms' total assets, TP. The paper also changes the proxy for trade credit granted by using the trade receivables scaled by firms' total assets, TR. The use of both measures is very useful in investigating trade credit because the variable days to pay accounts payable (DPA) is a proxy for how long the 
term of credit granted by suppliers is, and the variable TP is a proxy for the amount of credit granted to customers. For this regression, some data is lost because of missing values for the new dependent variable and, as a consequence, the model is run with 605 observations. Table 17 presents the results for robustness.

Table 17: Estimations results - robustness checks

\begin{tabular}{|c|c|c|c|}
\hline Explanatory Variables & (I) & (II) & (III) \\
\hline \multirow{2}{*}{$\mathrm{TR}_{\mathrm{it}}$} & $0.026^{*}$ & $0.06 *$ & $0.05 *$ \\
\hline & $(0.01)$ & (0.01) & $(0.01)$ \\
\hline \multirow[t]{2}{*}{ TR $_{\mathrm{it}} * \mathrm{CRISIS}_{\mathrm{it}}$} & - & $0.02 *$ & - \\
\hline & - & $(0.00)$ & - \\
\hline \multirow[t]{2}{*}{$\mathrm{PI}_{\mathrm{it}}$} & $0.02 *$ & $0.02 *$ & $0.03 *$ \\
\hline & $(0.00)$ & $(0.00)$ & $(0.00)$ \\
\hline \multirow[t]{2}{*}{$\mathrm{PI}_{\mathrm{it}}{ }^{*} \mathrm{CRISIS}_{\mathrm{it}}$} & - & - & $0.02 *$ \\
\hline & - & - & $(0.00)$ \\
\hline \multirow{2}{*}{ SIZE $_{\text {it }}$} & 0.002 & 0.002 & 0.001 \\
\hline & $(0.002)$ & $(0.001)$ & $(0.001)$ \\
\hline \multirow[t]{2}{*}{ FIX $_{\text {it }}$} & $-0.10^{*}$ & $-0.10^{*}$ & $-0.08^{*}$ \\
\hline & $(0.02)$ & $(0.01)$ & $(0.01)$ \\
\hline \multirow[t]{2}{*}{$\mathrm{IO}_{\mathrm{it}}$} & $0.003^{*}$ & $0.004 *$ & $0.004 *$ \\
\hline & $(0.000)$ & $(0.000)$ & $(0.000)$ \\
\hline \multirow[t]{2}{*}{$\operatorname{ASTU}_{\text {it }}$} & $0.02 *$ & $0.01 * *$ & 0.004 \\
\hline & $(0.004)$ & $(0.003)$ & $(0.003)$ \\
\hline \multirow[t]{2}{*}{ Constant } & $0.07 *$ & $0.08 *$ & $0.08 *$ \\
\hline & $(0.03)$ & $(0.02)$ & $(0.02)$ \\
\hline$T$ & - & 12.35 & 10.51 \\
\hline$z_{1}$ & $51.62(6)$ & $83.67(7)$ & $45.18(7)$ \\
\hline$z_{2}$ & $3.05(3)$ & $7.97(3)$ & $7.93(3)$ \\
\hline$z_{3}$ & $6.87(3)$ & $9.79(3)$ & $18.90(3)$ \\
\hline$m_{1}$ & -2.13 & -2.12 & -2.09 \\
\hline$m_{2}$ & 0.62 & 0.75 & 0.79 \\
\hline Hansen & 111.09 (98) & 123.39 (109) & 123.81 (109) \\
\hline
\end{tabular}

As shown in Column I, variables TR, PI, FIX, and IO keep the same sign, which reinforces the previous findings and supports Hypotheses 1,3, and 5, in that suppliers have advantages over banks in acquiring information about buyers' future prospects; that firms delay collection from their customers and, then, demand long term trade credits from their suppliers, and credit-constrained firms such as those with a high probability of insolvency and limited collateral, use more trade credit finance. The main difference here when 
compared with the previous estimation is that SIZE is not significant and the coefficient of ASTU becomes significant.

Columns 2 and 3 show the results for both extended models, one that CRISIS interacts with TD and the other that CRISIS interacts with PI. As can be seen, the results again provide evidence in favor of Hypotheses 6 and 7 while the remaining coefficients keep the same signs. These results provide an excellent robustness check for the hypotheses.

Therefore, trade credit use depends on time-invariant factors such as restrictions to formal credit, investment opportunities, market bargaining power and credit granted, but also depends on time-variant factors such as an economic crisis. The crisis can cause an increase in the restrictions for obtaining credit from financial institutions. So, in these periods, although suppliers can tighten the terms of credit to high risk firms, these buyers will postpone payment to suppliers as a way to avoid the liquidation risk, since their clients cannot pay them on time and because the formal credit markets neglect them and therefore suppliers are their last source of finance.

\section{IV.6. Conclusions}

This paper tests the substitution hypothesis between trade credit and bank credit. The paper also tests for the argument that suppliers have advantages in acquiring information about buyers' future prospects, that large buyers have bargaining power to demand better terms of credit from suppliers, and that, during an economic crisis, a contagion effect occurs in the granting of trade credit. The explanation for trade credit considers that it is a result of time-variant and time-invariant determinants.

Regarding the time-invariant determinants, trade credit received by firms depends on: their bargaining power to acquire long periods of credit from suppliers; the existence of high levels of investment opportunities and whether they have broad access to financing by financial institutions. As regards the time-variant determinants, trade credit depends on the insolvency risk of buyers. If buyers are highly vulnerable to an economic and credit contraction resulting from an economic crisis, then they will delay payments to suppliers. 
This study contributes to understanding the consequences of economic crises on the financing of economic activities. In this vein, an important conclusion drawn from this research is that suppliers act as valuable agents to offset credit tightening from financial institutions when they grant trade credit to low-credit rated firms. Suppliers also act by correcting information asymmetries between banks and firms, because they have better information about firms' investment opportunities and this advantage allows them to finance the net present value projects of their customers that otherwise go unfinanced and not started. Taking this argument into account, financial intermediaries need to find a way to diminish their lack of knowledge about firms' investment opportunities and future prospects. Although this paper sheds some light on the fact that during economic crises trade credit can offset banks' credit tightening, this compensation can only occur during a short period. After that, suppliers are also credit constrained and then reduce the level of trade credit. Understanding this fact is valuable to governments trying to take preemptive actions to mitigate the negative effects of a crisis on the economy. 


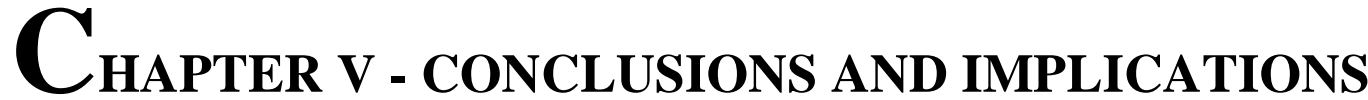

The purpose of this study has been to examine the main determinants of trade credit extended and demanded by firms. We split them into two types of determinants of trade credit: internal and external. The first of them considers some firm characteristics such as their size, the type of the product sold, the buyer's risk, the proportion of fixed assets, profitability, investment opportunities, and so on. The latter includes some legal aspects in which firms are involved or the economic situation that the country of the firm is going through.

In particular, this study shows that the trade credit extended by firms does not depend only on a seller trade credit policy, but also depends on the customer's credit requirements, which is a function of the seller reputation. This study also demonstrates that trade credit extended also depends on the level of creditor protection, according to the commercial code of the country in which the firm resides. Our research also reveals that the accounting practices of a country, determined by the law, also influence the trade credit extended by suppliers to their customers. In regard to the use of trade credit, it is also demonstrated that it depends on firms' ability to obtain funds from financial intermediaries and depends on their investment opportunities as well. It is also shown that economic crises affect trade credit use and cause a contagion of trade credit among suppliers and their customers.

Specifically, based on the agency theory, this study complements the commercial argument to explain trade credit extended, in which, in asymmetric information conditions, firms sell on credit to allow clients a period of time to check the real quality of the products bought before paying for them. We add to this argument that, under conditions of asymmetric information, sellers do not really know the creditworthiness of their clients and, therefore, they will tighten the terms of credit.

The findings of this study are consistent with previous arguments that firms sell on credit to allow clients to check the quality of the products before paying for them. Indeed, we find empirical evidence that high reputation firms, that is, those larger, highly profitable firms with a high proportion of fix assets, give less credit than firms whose reputations are 
not consolidated in the market in which they act. The argument that firms are likely to match the maturities of the contract terms for their payables and receivables was also confirmed and supported by the empirical evidence found. We also found that high risk firms will receive less trade credit from suppliers. In short, this finding seems to indicate that trade credit is driven by a trade-off between two phenomena, adverse selection and moral hazard.

Based on previous literature that provides empirical evidence of a relationship between legal rules and finance, we advance in our study and find empirical evidence supporting the argument that when companies belong to different countries, where legal rules are different, specifically for the case of creditor protection and accounting standards, the risk in granting credit to customers may be enhanced or mitigated depending on these rules. When these legal aspects were introduced as an interaction in the agency model using a sample of firms from 13 countries from different legal families, we found that high levels of creditor protection and high quality in the accounting rules mitigate the moral hazard phenomenon that exists in the agency relationship between suppliers and their customers.

Our findings reveal that legal features affect the trade credit obtained by firms as they moderate the credit risk. No one has previously tested for this impact on trade credit by using as an argument their role as a moderator in the moral hazard phenomenon. These results reveal what we consider to be one of the major causes of the cross country differences in the levels of trade credit use. As French-civil-law countries offer creditors the weakest protection and the weakest quality in accounting, any kind of credit will be hard negatively affected in these countries, including trade credit.

Focusing on trade credit demand, we then investigated the occurrence of trade credit contagion during economic shocks. For this study, we analyzed firms from three countries that have recently undergone an economic crisis, Argentina, Brazil and Turkey. Our results are consistent with previous arguments that trade credit and bank credit are substitutes. According to our results, firms presenting low levels of fixed assets and a high probability of insolvency use more trade credit. These findings were expected because firms with low levels of fixed assets are unlikely to obtain funds from banks as a consequence of the absence of assets to use as collateral. Firms with a high probability of insolvency are also banished from formal credit because they are high risk. In both cases, firms must apply for 
credit from suppliers. Results also suggest the consistency of the argument that nonfinancial firms have information advantages over formal lenders in checking the future perspectives of a firm. We find that firms with more investment opportunities receive more trade credit from suppliers.

Regarding the impact of economic crises on trade credit demand, our main finds suggest the occurrence of trade credit contagion in the supply chain. Results indicate that during a financial crisis, firms presenting high levels of accounts receivables will postpone payments to suppliers in order to avoid insolvency, since they may not succeed in collecting them in time. This behavior will lead to a contagion effect in the supply chain since firms' suppliers may act in exactly the same manner at the time of the payment of the goods or services contracted over their own suppliers. We also found that credit constrained firms, such as those presenting a high probability of insolvency, rely more on credit from suppliers. However, our empirical evidence suggests that this reliance is enhanced during economic crises. In other words, our results indicate that, on the one hand, suppliers tend to tighten terms of credit to high risk firms during economic crises, and on the other hand, customers will delay payments to suppliers since they have no other alternative source of funds. This finding is another piece of empirical evidence of the occurrence of trade credit contagion during economic crises; since suppliers facing difficulties in collecting their trade receivables are likely to postpone their trade payables to their own suppliers.

As we can see through our empirical evidence, this study is especially important for managers, policymakers, and researchers. Managers will profit from understanding the main determinants of trade credit, which are useful in planning trade credit policies. The knowledge of the type of product (perishable or not, for example) for which customers are likely to require large terms of credit is particularly important for them. Some aspects of the law are also important in the decision of selling on credit or not. Furthermore, as these aspects vary depending on the country, those firms that act in more than one country can take special advantage of this information to decide about different terms of credit. Understanding customer behaviour during economic crises is also very important for managers as it allows them to calculate more precisely the likelihood of the appearance of bad debts. Policymakers can benefit from this research since it allows them to understand that the impacts of financial crises go further than the financial systems, also affecting the 
real economy, and to realize that trade credit may not mitigate the lack of credit from financial institutions. This research also permits them to understand the consequences of a weak accounting system or low levels of creditor protection in the risk of credit supported, not only by banks but also by suppliers. The direct implication for the academic community is the use of the agency theory to explain trade credit granted by suppliers and its immediate consequences; trade credit terms are not only determined by suppliers' own decisions but also by customers' demand for long credit periods (trade off). The impact of legal features and economic crises on trade credit is another step taken by this study that should be incorporated into the explanatory models of trade credit.

To summarize, the thesis proved in this work is as follows: "Trade credit demanded and extended by firms is a result of the influence of internal factors (such as the moral hazard, the adverse selection, the bargaining power and the investment opportunities presented by the customer firm) and is also influenced by some external factors that characterize the legal and the economic environment (such as the level of creditor protection, the accounting standards and the economic situation)." 


\section{REFERENCES}

Akyurek, C. (2006) The Turkish crisis of 2001: a classic? Emerging Markets Finance and Trade, 42, 1, 5-32.

Akyüz, Y. and Boratav, K. (2003) The making of the Turkish financial crisis. World Development, 31, 9, 1549-1566.

Alphonse, P., Ducret, J. and Eric, S. (2004) When trade credit facilitates access to bank finance: evidence from US small business data, EFMA 2004 Basel Meetings Paper.

Arellano, M. and S. Bond. (1991) Some tests of specification for panel data: Monte Carlo evidence and an application to employment equations. Review of Economic Studies 58, 277-297.

Bardes, B. (2002) Délais de paiement et solde du crédit interentreprises de 1989 à 2001, Bulletin de la Banque de France, 108, 103-121.

Bastos, R. and Pindado, J. (2007) An agency model to explain trade credit policy and empirical evidence, Applied Economics, 39, 2631-2642.

Bastos, R. and Pindado, J. (2009) Trade credit, creditor protection and accounting standards: evidence from an international sample, Revista de Economía Financiera, 17, 46-69.

Baum, C. F., Caglayan, M. and Ozkan, N. (2003) The impact of macroeconomic uncertainty on trade credit for non-financial firms, Boston College Department of Economics: Boston College Working Papers in Economics, $\mathrm{n}^{\circ} 566$.

Bevan, A. A. and Danbolt, J. (2002) Capital structure and its determinants in the UK - a decompositional analysis, Applied Financial Economics, 12, 159-170.

Biais, B. and Gollier C. (1997), Trade credit and credit rationing, Review of Financial Studies, 10, 903-937.

Blasio, G. de. (2005), Does trade credit substitute bank credit? Evidence from firm-level data, Economic Notes, 34, 85-112.

Blundell, R. and Bond, S. (1998) Initial conditions and moment restrictions in dynamic panel data models, Journal of Econometrics, 87, 115-144.

Borde, S. F. and McCarty, D. E. (1998) Determining the cash discount in the firm's credit policy: an evaluation, Journal of Financial and Strategic Decisions, 11, 41-49. 
Brick, I. E. and Fung, W. K. H. (1984) Taxes and the theory of trade debt, Journal of Finance, 39, 1169-1176.

Brennan, M. J.; Maksimovic, V. and Zechner, J. (1988) Vendor financing, Journal of Finance, 43, 1127-1141.

Burkart, M. and Ellingsen, T. (2004) In-kind finance: a theory of trade credit, American Economic Review, 94, 569-590.

Chote, R. and Daniel, D. (1998) Asia's ripple effect: In the second of two articles on the anniversary of the financial crisis, Robert Chote and Daniel Dombey look at how its influence has spread to other emerging markets, Financial Times, 2 (July), pg. 25, London (UK).

Danielson M. G. and Scott, J. A. (2004) Bank loan availability and trade credit demand, Financial Review, 39, 579-600.

Delannay, A. and Weill, L. (2004) The determinants of trade credit in transition countries, Economics of Planning, 37, 173-193.

Deloof, M. and Jegers, M. (1996) Trade credit, product quality, and intragroup trade: some European evidence, Financial Management, 25, 33-43.

Deloof, M. and Jegers, M. (1999) Trade credit, corporate groups, and the financing of Belgian firms, Journal of Business Finance \& Accounting, 26, 945-967.

Deloof, M. and Overfelt, W. V. (2010) Trade credit and bank relationships: evidence from Pre-World War I Belgium, Applied Economics, Forthcoming.

Demirgüç-Kunt, A. and Maksimovic, V. (2001) Firms as financial intermediaries: evidence from trade credit data, World Bank Working Paper, $n^{\circ} .2696$.

Djankov, S., McLiesh C. and Shleifer, A. (2007) Private credit in 129 countries, Journal of Financial Economics, 84, 229-329.

Emery, G. W. (1984) A pure financial explanation for trade credit, Journal of Financial and Quantitative Analysis, 19, 271-285.

Emery, G. W. (1987) An optimal financial response to variable demand, Journal of Financial and Quantitative Analysis, 22, 209-225.

Emery, G. W. and Nayar, N. (1998) Product quality and payment policy, Review of Quantitative Finance and Accounting, 10, 269-284. 
Fabbri, D. and Klapper, L. F. (2008) Market power and the matching of trade credit terms, World Bank Policy Research Working Paper, no 4754.

Fazzari, S., Hubbard, G. and Petersen, B. (1988) Financing constraints and corporate investment, Brooking Papers on Economic Activity, 1, 141-195.

Fazzari, S., Hubbard, G. and Petersen, B. (2000) Investment-cash flow sensitivities are useful: A Comment on Kaplan and Zingales, The Quarterly Journal of Economics, $115,695-705$.

Ferrari, A. and Cunha, A. M. (2008) The origins of the Argentine crisis: a suggested interpretation. Economia e Sociedade, 17, 2 (33), 47-80.

Ferris, J. S. (1981) A transactions theory of trade credit use, Quarterly Journal of Economics, 96, 243-270.

Fisman, R and Love, I. (2003) Trade credit, financial intermediary development, and industry growth, Journal of Finance, 58, 353-374.

Frank, M. and Maksimovic, V. (1998) Trade credit, collateral, and adverse selection, SSRN Working Paper, $\mathrm{n}^{\circ} .87868$.

Friedman, M. and Schwartz, A. J. (1963) A monetary history of the United States, 1867 1960, Princeton, NJ: Princeton University Press.

Fukuda, S., Kasuya, M. and Akashi, K.(2006) The role of trade credit for small firms: an implication from Japan's banking crisis, The University of Tokyo: CIRJE Discussion Papers Series $\mathrm{n}^{\circ} \mathrm{F}-440$.

Galindo, A. and Micco, A. (2007) Creditor protection and credit response to shocks, World Bank Economic Review, 21, 413-438.

Giesecke, K. and Weber, S. (1979) Credit contagion and aggregate losses, Journal of Economics, Dynamics \& Control, 30, 741-767.

Gopinath, C. (1995) External influence on firms: an exploratory model of bank strategies, Journal of Business Research, 34, 133-143.

Han, K., Suk, H. and Suk, D. (1999) Ownership structure and firms performance: international evidence, Multinational Business Review, 7, 92-98.

Hill, N.C. and Riener, K.D. (1979) Determining the cash discount in the firm's credit policy, Financial Management, 8, 68-73. 
Horen, V. H. (2005) Trade credit as a competitiveness tool; evidence from developing countries, SSRN Working Paper, ${ }^{\circ} 562410$.

Jensen, M. C. and Meckling, W.H. (1976) Theory of the firm: managerial behavior agency costs and ownership structure, Journal of Financial Economics, 3, 305-360.

Jorion, P. and Zhang, G. (1976) Credit contagion from counterparty risk, Journal of Finance, 64, 2053-2087.

Kandori, M. (1992) Social norms and community enforcement, Review of Economic Studies, 59, 63-80.

Kaplan, S. N. and Zingales, L. (1997) Do investment-cash flow sensitivities provide useful measures of financing constraints?, The Quarterly Journal of Economics, 112, 169215.

Kaufman, G. (1994) Bank Contagion: A review of the theory an evidence, Journal of Financial Services Research, 8, 123-150.

Kazmin, A., Lamont, J., and Leahy, J. (2008) India in emergency step to unblock trade credit, Financial Times, 17 (Nov), pg. 3, London (UK).

La Porta, R., Lopez-de-Silanes, F., Shleifer A. and Vishny, R. W. (1998) Law and finance, Journal of Political Economy, 106, 1113-1155.

La Porta, R., Lopez-de-Silanes, F., Shleifer A. and Vishny, R. W. (1997) Legal determinants of external finance, Journal of Finance, 52, 1131-1150.

Lee, Y. W. and Stowe, J. D. (1993) Product risk, asymmetric information, and trade credit, Journal of Financial and Quantitative Analysis, 28, 285-300.

Levine, R. (2002) Bank-based or Market-based financial systems: which is better?", Journal of Financial Intermediation, 11, 398-428.

Levine, R. (1998) The legal environment, banks, and long-run economic growth, Journal of Money, Credit and Banking, 30, 596-613.

Long, M. S., Malitz, I. B. and Ravid, S. A. (1993) Trade credit, quality guarantees, and product marketability', Financial Management, 22, 117-127.

Love, I., Preve, A. P. and Sarria-Allende, V. (2007) Trade credit and bank credit: evidence from recent financial crises, Journal of Financial Economics, 83, 453-469.

Marotta, G. (1997) Does trade credit redistribution thwart monetary policy? Evidence from Italy, Applied Economics, 29, 1619-1629. 
Marotta, G. (2005) When do trade credit discounts matter? Evidence from Italian firm-level data, Applied Economics, 37, 403-416.

McMillan, J. and Woodruff, C. (1999) Interfirm relationships and informal credit in Vietnam, The Quarterly Journal of Economics, 114, 1285-1320.

Meltzer, A. H. (1960), Mercantile credit, monetary policy, and size of firms, Review of Economics and Statistics, 42, 429-437.

Mian, S. L. and Smith C. W. (1992) Accounts receivables management policy: theory and evidence, Journal of Finance, 47, 169-200.

Mottner, S. and Smith, S. (2009) Wal-Mart: Supplier performance and market power, Journal of Business Research, 62, 535-541.

Moulton, B. (1986) Random group effects and the precision of regression estimates, Journal of Econometrics, 32, 385-397.

Moulton, B. (1987) Diagnostics for group effects in regression analysis, Journal of Business and Economic Statistics, 5, 275-282.

Ng, C. K., Kiholm Smith, J. and Smith, R. L. (1999) Evidence on the determinants of credit terms used in interfirm trade, Journal of Finance, 54, 1109-1130.

Nilsen, J. (2002) Trade credit and the bank lending channel, Journal of Money, Credit, and Banking, 34, 226-253.

Niskanen, J. and Niskanen, M. (2006) The determinants of corporate trade credit policies in a bank-dominated financial environment. The case of Finnish small firms, European Financial Management, 12, 81-102.

Oh, J. S. (1976) Opportunity cost in the evaluation of investment in accounts receivable, Financial Management, 5, 32-36.

Paul, S. and Wilson, N. (2007) The determinants of trade credit demand: survey evidence and empirical analysis, Journal of Accounting - Business \& Management, 14, 96-116.

Petersen, M. A. and Rajan, R. G. (1994) The benefits of lending relationships: evidence from small business data, The Journal of Finance, 49, 3-37.

Petersen, M. A. and Rajan, R. G. (1995) The effect of credit market competition on lending relations, The Quartely Journal of Economics, 60, 407-444.

Petersen, M. A. and Rajan, R. G. (1997) Trade credit: theories and evidence, Review of Financial Studies, 10, 661-692. 
Peterson, M., Ekici, A. and Hunt, D. M. (2010) How the poor in a developing country view business' contribution to quality-of-life 5 years after a national economic crisis, Journal of Business Research, Forthcoming.

Pike, R., Cheng, N. S., Cravens, K. and Lamminmaki, D. (2005) Trade credit terms: asymmetric information and price discrimination evidence from three continents, Journal of Business Finance \& Accounting, 32, 1197-1236.

Pindado, J., Rodrigues, L. and De la Torre, C. (2006) How does financial distress affect small firms financial structure?, Small Business Economics, 26, 377-391.

Pindado J., Rodrigues L. and De La Torre C. (2008) Estimating financial distress likelihood, Journal of Business Research, 61, 995-1003.

Pindado, J., Rodrigues, L. and De La Torre, C. (2008) How do insolvency codes affect a firm's investment? International Review of Law and Economics, 28, 227-238.

Prowse, S. D. (1990) Institutional investment patterns and corporate financial behavior in the US and Japan, Journal of Financial Economics, 27, 43-66.

Rodriguez-Rodriguez, O. M. (2008) Firms as credit suppliers: an empirical study of Spanish firms, International Journal of Managerial Finance, 4, 152-173.

Safavian, M. and Sharma, S. (2007) When do creditor rights work? Journal of Comparative Economics, 35, 484-508

Schwartz, R. A. and Whitcomb, D. K. (1979) The trade credit decision, in Handbook of Financial Economics (Ed.) J. L. Bicksler, North-Holland, Amsterdam, 257-273.

Schwartz, R. A. (1974) An economic model of trade credit, Journal of Financial and Quantitative Analysis, 9, 643-657.

Smith, J. K. (1987) Trade credit and informational asymmetry, Journal of Finance, 42, 863-872.

Titman, S. and Wessels, R. (1988) The determinants of capital structure choice, Journal of Finance, 43, 1-19.

Thomsen, S. and Pedersen, T. (2000) Ownership structure and economic performance in the largest European companies, Strategic Management Journal, 21, 689-705.

Tsuruta, D. (2007) Credit contagion and trade credit supply: evidence from small business data in Japan, RIETI Discussion Paper Series, $\mathrm{n}^{\circ}$ 07-E-043. 
Uesugi I. and Yamashiro G. M. (2008) The relationship between trade credit and loans: evidence from small businesses in Japan, International Journal of Business, 13, 141163.

Wei, P. and Zee, S. M. L. (1997) Trade credit as quality signal: an international comparison, Managerial Finance, 23, 63-72.

Wilner, B. S. (2000) The exploitation of relationships in financial distress: the case of trade credit, Journal of Finance, 55, 153-178.

Zambaldi, F., Aranha, F., Lopes, H. and Politi R. (2010) Credit grant to small firms: a brazilian case, Journal of Business Research; Forthcoming.

Zurawicki, L. and Braidot, N. (2005) Consumers during crisis: responses from the middle class in Argentina, Journal of Business Research; 58, 1100-1109. 